NBER WORKING PAPER SERIES

\title{
INDIRECT COSTS OF GOVERNMENT AID AND INTERMEDIARY SUPPLY EFFECTS: LESSONS FROM THE PAYCHECK PROTECTION PROGRAM
}

\author{
Tetyana Balyuk \\ Nagpurnanand R. Prabhala \\ Manju Puri \\ Working Paper 28114 \\ http://www.nber.org/papers/w28114 \\ NATIONAL BUREAU OF ECONOMIC RESEARCH \\ 1050 Massachusetts Avenue \\ Cambridge, MA 02138 \\ November 2020
}

We thank Viral Acharya, Tarun Chordia, Sanjiv Das, Mike Faulkender, Clifton Green, Narasimhan Jegadeesh, Simi Kedia, Dasol Kim, Gonzalo Maturana, Alessandro Rebucci, Pablo Slutzky, Sascha Steffen, and seminar participants at the Emory University Finance Brownbag for helpful comments and suggestions. Ethan Forgas provided excellent research assistance. Tetyana Balyuk gratefully acknowledges a grant from the John Robson Program for Business, Public Policy, and Government. All errors are our own. The views expressed herein are those of the authors and do not necessarily reflect the views of the National Bureau of Economic Research.

NBER working papers are circulated for discussion and comment purposes. They have not been peer-reviewed or been subject to the review by the NBER Board of Directors that accompanies official NBER publications.

(C) 2020 by Tetyana Balyuk, Nagpurnanand R. Prabhala, and Manju Puri. All rights reserved. Short sections of text, not to exceed two paragraphs, may be quoted without explicit permission provided that full credit, including $(\odot$ notice, is given to the source. 
Indirect Costs of Government Aid and Intermediary Supply Effects: Lessons From the Paycheck Protection Program

Tetyana Balyuk, Nagpurnanand R. Prabhala, and Manju Puri

NBER Working Paper No. 28114

November 2020

JEL No. E61,G32,G38,H81

\begin{abstract}
The \$669 billion Paycheck Protection Program (PPP) provides highly subsidized financing to small businesses. The PPP is a positive shock in financing supply to the small, highly constrained publicly listed firms in our sample and has average positive treatment effects. Yet, uptake is not universal. In fact, several firms return PPP funds before use, and curiously, experience positive valuation effects when they do so. These firms desire and the markets value the release from government oversight even if it means giving up cheap funding. The PPP is also a demand shock to the banks making PPP loans. Intermediary supply effects shape PPP delivery. Larger borrowers enjoy earlier PPP access, an effect that is more pronounced in big banks. The results have implications for policy design, the costs of being public, and bank-firm relationships.
\end{abstract}

Tetyana Balyuk

Goizueta Business School

Emory University

1300 Clifton Rd

Atlanta, GA 30322

tetyana.balyuk@emory.edu

Nagpurnanand R. Prabhala

The Johns Hopkins Carey Business School

100 International Drive

Baltimore, MD 21202

prabhala@jhu.edu

\author{
Manju Puri \\ Fuqua School of Business \\ Duke University \\ 100 Fuqua Drive \\ Durham, NC 27708-0120 \\ and NBER \\ mpuri@duke.edu
}


The Covid-19 pandemic is a significant black swan event. After being first noticed in China's Hubei province, Covid-19 was soon recognized as a major health threat due to its high transmissibility, its high mortality rate, and because relatively little was known about effective ways to treat or prevent it. The speed at which it spread and the damage it has wrought on economies around the world are unprecedented. As of September 2020, there are over 33 million Covid cases worldwide and 1 million deaths.

Besides the threat to life, Covid-19 has also threatened livelihoods. Interactions between people are a primary source of transmitting the Covid-19 virus. Thus, high-contact sectors such as airlines, retail stores, and hotels closed virtually instantly. Factories and officers scaled or cut back to avoid transmission and individuals faced significant adjustments in even basic day-to-day activities. The net result of these forces was a wide, deep, and speedy economic contraction across the globe. In the U.S., GDP decreased by close to a third within a quarter and unemployment jumped from historical lows of under $4 \%$ to nearly $15 \%$.

Given the contraction in both the household and the business sectors, fiscal stimulus from the government has been a key focus for economic revival. In the U.S., its centerpiece is the $\$ 2$ trillion Coronavirus Aid, Relief, and Economic Security (CARES) Act, which extends support in varying degrees to workers, businesses, and local governments. Our focus is on the portion of the CARES Act package designed to aid small businesses, the Paycheck Protection Program (PPP). This program was allocated $\$ 669$ billion, about a third of the overall CARES Act package, and provided cheap, forgivable debt to small businesses.

We study the PPP for small public firms. Even in normal times, the small firms in our sample - typically microcaps in the lowest capitalization decile - face extreme financial constraints. The PPP is a shock in the supply of finance to these firms. It seems to be a very desirable source of funding as it provides liquidity, does so with little lag, and has attractive terms including a concessional 1\% interest rate and forgiveness for proceeds used in eligible ways. Not surprisingly, taking PPP funds is associated with positive announcement effects.

Yet, we find that the firms appear reluctant to take PPP funds, to the point where several firms that took PPP funds return the money without using it and in fact, experience valuation increases when returning the subsidized funding. Our sample firms appear to perceive large indirect costs of taking government funding, likely due to perceptions about subjectivity in the scrutiny of PPP recipients and the special targeting of public firms in these audits. Expanding on these results, interpreting the findings, and understanding their economic implications is one focus of our study.

The second leg of our study is motivated by the observation that the PPP is a large-scale shock in loan demand for the participating banks that make the loans. This is especially true in the early stages of the program when the rush for PPP funds was overwhelming, requiring 
rapid processing of applications and prompt disbursements to approved firms. An additional issue was that the program funds ran out quickly and was only remedied weeks later through the appropriations process. Banks were forced to prioritize clients. Thus, observing the types of borrowers who gain early access to PPP funds is a unique opportunity to understand bank decision-making in times of scarce resources.

Accordingly, our research design examines the differences in allocations in the early stages relative to later stages. We first cut the data by borrower type. From a demand perspective, small firms, which are perhaps more financially constrained and more vulnerable, should access PPP funds sooner. However, we find that larger borrowers receive priority in early stages. Supply-side intermediary effects thus matter and shape how PPP funds flow to small businesses. We then cut the results by bank type, effectively comparing how big and small banks differ in their early versus late allocation between small and large firms. The effect appears to be more pronounced for the big banks, who seem to have a greater propensity to prioritize larger clients early in PPP access.

We briefly discuss the data, the results, and their plausible economics next. We obtain data on the public firms using PPP funds from disclosures filed by firms. Many firms disclose their access to PPP in their 8-K filings but some do so in 10-Q's and 10-K's. As the reporting within and across disclosures is not standard, being spread across more than a half-dozen items in the filings and the attached promissory notes, we search all 8-K, 10-Q, and 10-K filings by public firms filed between January 1, 2020 and August 15, 2020, one week after the PPP closed on August 8, 2020. A combination of keyword searches and intensive manual screening identifies a preliminary list of 731 PPP applicants. We match these using some combination of firm names, tickers, CUSIPs and CIKs with returns from Yahoo! Finance, accounting information from COMPUSTAT and exclude certain firms (e.g., financials, SPACs). The usable sample for most tests includes about 553 public firms.

The PPP provides extraordinarily cheap and readily available funding to small firms. These firms face quantitative constraints that impair growth (Petersen and Rajan (1994); Whited and Wu (2006); Hadlock and Pierce (2010); Banerjee and Duflo (2014)) and receive funds in the midst of an economic crisis. Taking PPP funds does not appear to hurt firm value. In fact, share values increase with positive "bang for the buck" treatment effects even after adjustment for partial anticipation. Nevertheless, firms appear somewhat reluctant to take PPP funds. In fact, over 100 firms that manage to qualify for, apply for, and take PPP funds return the funds without using them. While returning cheap funds should decrease share prices by the net present value of the subsidy lost, returners experience positive announcement effects, more than making up for the subsidy lost in cheap financing.

Why do firms seem to turn away from PPP funds? Two explanations present themselves 
immediately. One is the inflexibility required for forgiveness, which only applies to funds used for specified purposes within a specified time and is reduced if the firms lay off employees. However, even if firms do not find it optimal to comply, the net effect is that the PPP funds become a $1 \%$ loan, which is still inexpensive. A second explanation is that firms may have ex-post been able to raise other sources of funding. However, even in normal times, it is hard to beat the $1 \%$ to negative rate in PPP funding. We know of no cases (or programs) where funds are as cheap as in the PPP.

It then appears that the small firms in our sample perceive some indirect costs of taking PPP funds. If so, the subsidy lost from not taking PPP funds is made up by the savings in indirect costs. What could be the nature of these indirect costs? They appear to arise out of the ambiguity concerning the scope and implementation of the scrutiny of PPP recipients, especially the publicly listed ones. Extensive research points out that the wariness is not unfounded. Firms can suffer significant reputational losses and disruptions from a negative determination in such investigations. We elaborate on this point in greater detail next with specific attention to the rules laid out by the PPP.

As in programs using taxpayer money, PPP recipients are subject to audit. The scope includes conditions for eligibility, amount, the use of proceeds, and forgiveness and extends for several years beyond the program. Two features of the PPP audit process are especially relevant. One, it is highly subjective. For instance, eligibility requires a certification that the PPP loan is necessary for ongoing operations taking into account current activity and also access to other sources of liquidity "in a manner not significantly detrimental to the business." These are clearly subjective standards. The direct financial penalties - the return of principal and interest - are not likely relevant, although we note that the SBA does retain broad, sweeping powers to "... [to] pursue any available remedies," a clause that maintains subjectivity in enforcement penalties.

An equally - or perhaps more - important point is that the audit guidance has clearly and repeatedly taken special aim at public firms. For example, the SBA clarifies that “... it is unlikely that public firms with substantial market value and access to capital markets can make this certification in good faith." It is unclear what constitutes substantial market value or access. There are no safe harbors provided for firms to avoid an adverse determination. Moreover, the fungibility of funds makes it easy to attribute any use of funds - investment, financing, payout, or compensation - to PPP funding and trigger negative media coverage. ${ }^{1}$

Should such investigations concern firms? Research certainly suggests so. Simply be-

\footnotetext{
${ }^{1}$ Consider the story in Washington Post on September 26, 2020 "Publicly traded firms paid dividends, bought their own stock after receiving PPP loans to pay employees" at https://www.washingtonpost.com /business/2020/09/24/dividends-buybacks-ppp-loans.
} 
ing an investigation target triggers significant drops in share prices. The evidence goes back to FTC false advertising investigations (Jarrell and Peltzman (1985)), the Alexander (1999) study of violations of government contracts, and the penalties from SEC investigations (Haslem, Hutton, and Smith (2017)). With financial misconduct, the loss in value far exceeds the value of financial penalties. This is not surprising as investigations can take a long period of time to conclude and are quite disruptive when in progress, imposing costs on both the senior managers and the directors of the targeted firms (Karpoff, Lee, and Martin (2008); Fich and Shivdasani (2007); Murphy, Shrieves, and Tibbs (2009)). Capital raising in the shadow of such investigations becomes difficult: Even a sophisticated market such as syndicated loans is not immune from its effects (Lin and Paravisini (2011)).

In our view, whether the prospect of these investigations matters to firms or not is an empirical issue. In our sample, firms seem to perceive that they are high enough that it is better to forego low-cost funding from the government. Moreover, markets appear to share this perception given the $3 \%$ announcement effect associated with the return of PPP funds.

To motivate the second leg of our analysis, we note that the PPP is not only a supply shock for firms but is also a shock to loan demand for participating banks. The initial rush for PPP funds overwhelmed banks, compounding which was an aggregate shortage of PPP funds because demand exceeded its initial supply of $\$ 349$ billion. Banks were thus forced to prioritize clients. Their decisions offer a rare - and clear - window into the bank lending decisions in times of scarce resources.

From the demand side, small firms need credit sooner as they are more constrained, weaker, and less resilient to shocks. From the supply side, banks could prioritize larger clients as they generate more current and future revenues. Which effect dominates? Empirically, large size is positively correlated with early access. Do prior relationships help mitigate these priorities? We examine this question using DealScan data on relationships. For the sample with DealScan data, we find no evidence that this is the case. The results are more consistent with banks providing preferential treatment for their larger clients. A related question is whether this pattern varies across big and small banks. This seems to be the case when we examine the difference-in-difference between early and late loans for big and small banks. The positive relation between size and early access and its strengthening for big banks is also robust in the universe of all PPP borrowings. The results suggest that besides loan demand, intermediary supply effects are important in directing PPP flows.

The results have interesting implications for banking research on why small firms do better with small banks. The traditional argument is that soft information is used more intensively by small banks (Stein (2002), Berger, Miller, Petersen, Rajan, and Stein (2005)). Our results suggest another rationale for pairing small firms with small banks. When capacity 
constraints arise - as in the PPP but also in other shocks that can arise from time to time - big banks may place larger clients ahead of their smaller ones. This effect is attenuated in small banks for whom small business lending is a mainstay of business. The negative externalities for small firms from being the "small fish in a big pond" in big banks seems worthy of further research.

The rest of the paper is organized as follows. Section I discusses the Covid-19 pandemic and the PPP program in response to the pandemic. Section II discusses the relevant literature. Section III describes the data used in the study. Section IV describes the firms that take PPP funding relative to the small-firm universe and the relevant treatment effects with econometric adjustments for Covid-period heterogeneity and the partial anticipation of treatment uptake. Section V reports results on firms that return PPP funds relative to the retainers and the related valuation effects. Section VI analyzes early versus late PPP applicants and the results concerning large and small PPP lenders. Section VII concludes.

\section{The Covid-19 Pandemic and the PPP}

\section{A. The Economic Effects of Covid-19}

The Covid-19 pandemic began to be recognized widely in December 2019, when a large number of individuals suffered from respiratory symptoms, often life-threatening, in China's Hubei province. The infections were subsequently attributed to a virus named as the novel Coronavirus (SARS-CoV-2). The virus spread to virtually all countries in the world within a short span of time and was declared as a worldwide pandemic by the end of January 2020. As of mid-September 2020, there are over 30 million cases and 962,000 deaths. See the Johns Hopkins Coronavirus Resource Center at https//coronavirus.jhu . edu.

In the U.S., the first Covid-19 case was reported in the state of Washington on January 15, 2020. Two weeks later, Covid-19 was recognized as a national public health emergency. The number of infections grew in a typical exponential path. One identified case on January 15, 2020 became seven cases as of January 31, 2020, 24 cases as of February 29, 2020, and reached 6.8 million cases by mid-September 2020 with nearly 200,000 deaths.

The economic spillovers from the Covid-19 took root as individuals recognized its easy transmissibility, its serious health consequences, and the lack of clear treatment options. As people self-isolated and as offices, businesses, and factories shut down or scaled back, an economic slowdown set in. Sectors that require face-to-face interaction such as tourism, airlines, or hospitality, came to a virtual standstill. Other firms contracted due to a slowdown in demand as well as cutbacks necessary to avoid spreading infections. The U.S. Bureau of 
Economic Analysis statistics show that U.S. GDP contracted by annualized $32.9 \%$ rate in the second quarter of 2020. The U.S. Bureau of Labor Statistics show that unemployment rate jumped from under $4 \%$ in February 2020 to $14.7 \%$ in April 2020 with a 15.2 million increase in the number of unemployed in a single month.

The downturn has had particularly severe effects on small businesses, as Chetty, Friedman, Hendren, Stepner, et al. (2020) show using real-time microdata on consumer spending, business revenues, and employment. These effects matter as small businesses are a major source of U.S. employment. A 2018 U.S. Small Business Administration report shows that U.S. businesses with less than 500 employees account for 58.9 million jobs, or $47.5 \%$ of the total. Thus, the failure of many small businesses could spark a broader economic contagion.

\section{B. The PPP Program Architecture}

In the U.S., the flagship program that aims to help small businesses is the Paycheck Protection Program (PPP). This is a significant portion of the Coronavirus Aid, Relief, and Economic Security (CARES) Act, which at $\$ 2$ trillion or $10 \%$ of the pre-pandemic U.S. GDP, is the single largest stimulus package in U.S. history. Figure 1 gives the time lines leading up to the passage of PPP. The original CARES package proposed in January 24, 2020 included $\$ 349$ billion for the PPP alongside $\$ 450$ billion for corporate loans, $\$ 301$ billion for household payments, and $\$ 250$ billion for expanded unemployment insurance. After significant legislative back and forth, procedural roadblocks were cleared for the CARES Act on March 24, 2020. The bill was passed by the legislature on March 25, 2020 and March 26, 2020 and signed into law by the U.S. President on March 27, 2020.

The initial amount allocated to the program under the CARES Act, $\$ 349$ billion, was exhausted shortly after applications started on April 2, 2020. The SBA stopped accepting new applications on April 16, 2020. An additional $\$ 320$ billion was introduced by the Paycheck Protection Program and Health Care Enhancement Act of 2020 signed into law on April 24, 2020, after which the SBA resumed accepting applications starting on April 27, 2020. The program was scheduled to terminate on June 30, 2020, but resumed accepting applications on July 6, 2020 until the final deadline of August 8, 2020, by when PPP disbursed $\$ 525$ billion to 5.21 million borrowers.

Program Features: The PPP is a forgivable collateral-free loan program administered through the Small Business Administration (SBA), a federal agency that guarantees the loans that are actually made by banks. The loans intend to help businesses maintain payroll and cover qualified overhead for about 12 weeks and carry an interest rate of $1 \%$ per year. The application process is straightforward. Borrowers apply through an approved financial 
institution (e.g., a bank), provide documentation relating to eligible expenses, and make certain representations and certifications. After approval, funds are disbursed by the banks.

Eligibility: Eligible borrowers are small firms as defined in the CARES Act. Firms should have a principal place of residence in the U.S., been in operation before February 15, 2020, and have less than 500 employees. Firms could also qualify according to other standards laid out by the SBA such as under Small Business Act, 15 U.S.C 632.

Amount and Terms: Borrowers can take up to 2.5 times the monthly payroll of up to $\$ 100,000$ per employee resident in the U.S with a hard cap of $\$ 10$ million per eligible entity. Forgiveness applies to amounts spent as per the program rules as amended from time to time. The principal not forgiven turns into a 5-year loan for loans made on or after June 5, 2020 and a 2-year loan otherwise unless both the lender and borrower agree to a 5-year term.

Spending PPP funds: The PPP incentivizes early spending of proceeds. Banks must make loans within 10 days of approval. Forgiveness applies to eligible payroll spent soon. The initial cap was 8 weeks but the June 2, 2020 PPP Flexibility Act (PPPFA) expanded the forgiveness period to the earlier of 24 weeks from disbursal or December 31, 2020 and reduced the minimum required payroll spending from $75 \%$ to $60 \%$ of the proceeds. Layoffs were disincentivized through reductions of forgiveness based on the number of layoffs other than employees who were offered and declined rehire. ${ }^{2}$

Certification: Borrowers receiving PPP funds must certify that "... the current economic uncertainty makes the loan necessary to support ongoing operations" and as per PPP Rule 31 issued on June 25, 2020 "... taking into account ... their ability to access other sources of liquidity" in a manner that is not significantly detrimental to the business. The SBA clarifies that it is unlikely that a public company with substantial market value and access to capital markets will be able to make the required certification in good faith.

Review: The SBA has indicated that all loans over $\$ 2$ million are subject to eligibility review but it can review other loans as well. If the review uncovers a negative finding, firms must return principal plus interest but the SBA reserves the right to seek any available remedies. Firms that repay PPP loans in full by May 7, 2020 - later extended to May 14, 2020 and again to May 18, 2020 - are deemed to have made the required certifications in good faith. The deadlines and their extensions have two contradictory readings. On the one hand, they do provide a safe harbor for borrowers. On the other hand, they also make salient and explicit the threat, if not strict intent, to audit recipients, especially public firms.

Lender Responsibilities and Fees: Lenders submit applications on behalf of borrowers and fund the loans and can rely on borrower certifications and representations. Lenders can sell

\footnotetext{
${ }^{2}$ The PPPFA let $50 \%$ of the employer portion of the payroll taxes be deferred to 2021 and $50 \%$ to 2022 . These costs could include payment to those furloughed, bonuses, and hazard pay.
} 
SBA loans into the secondary market, as clarified in an April 17, 2020 ruling. Lender fees as equal to $5 \%$ for loans up to $\$ 350,000,3 \%$ for loans between $\$ 350,000$ and $\$ 2,000,000$, and $1 \%$ for loans above $\$ 2,000,000$.

\section{Related Literature}

\section{A. Finance Related Covid-19 Research}

The Covid-19 pandemic has attracted a vast literature. For a curated collection of several hundred Covid Economics papers, see the website maintained by Center for Economic Policy and Research. ${ }^{3}$ From the stock market's viewpoint, Covid-19 was an extreme event. Baker, Bloom, Davis, Kost, Sammon, and Viratyosin (2020) find that during the Covid-19 pandemic, there are many days with extreme daily stock returns exceeding $2.5 \%$. No such moves were seen in the 1918-1920 Spanish flu, pandemic which eliminated 2\% of the world's population. In the 1957 and 1968 flu pandemics in the U.S., there were 9 jumps in 1957 and one in 1968. In contrast, from February 24, 2020 to April 30, 2020 there are 27 jumps, at least 23 of which are clearly related to Covid-19 news. Loughran and McDonald (2020) show that few of the 2018 disclosures by firms mention pandemics. Thus, it is plausible that the Covid-19 related news that triggered large movements were surprising.

Financing concerns became important during the Covid-19 pandemic. Hassan, Hollander, van Lent, and Tahoun (2020) show that textual disclosures reveal more financing concerns in the second quarter of 2020. See De Vito and Gomez (2020) for related simulations. Ramelli and Wagner (2020) show that debt and liquidity remain key concerns in the tone and content of conference calls. Acharya and Steffen (2020) show that high-rated firms accessed the market for cash while lower rated firms accessed funds from bank lines. Unrated firms do not display this dash for cash, perhaps because bank lines were unavailable to them. This point is relevant to our study as over $95 \%$ of our sample involves unrated firms. Acharya, Engle, and Steffen (2020) discuss the impact of the dash for cash on bank balance sheets.

Acharya et al. (2020) and Fahlenbrach, Rageth, and Stulz (2020) analyze the large dip in stock prices due to the Covid-19 crisis. In Acharya et al. (2020), the stock market reactions are less extreme for AAA-A firms than for BBB-B or unrated firms. Fahlenbrach et al. (2020) find that firms with less cash, lower book-to-market ratios, small firms, and firms with more short- or long-term debt to assets have worse returns, alongside Covid-19 affected industries.

Research has begun to examine policy responses to the Covid-19 pandemic. Granja, Makridis, Yannelis, and Zwick (2020) show in an ongoing real time analysis that the PPP has

\footnotetext{
${ }^{3}$ See https://cepr.org/content/covid-economics-vetted-and-real-time-papers-0.
} 
had limited impact on labor market outcomes. Kim (2020) argues that there is greater impact after accounting for bank constraints. Other studies include Bartik, Cullen, Glaeser, Luca, Stanton, and Sunderam (2020) and Bartlett and Morse (2020), who find positive impacts on very small businesses. Erel and Liebersohn (2020) examine the role of FinTech firms in PPP lending. Cororaton and Rosen (2020) report the characteristics of PPP applicants for a sample of 424 applicants, which are similar to those for our somewhat larger sample in Section IV. Hanson, Stein, Sunderam, and Zwick (2020) offer a theory in which government intervention should take the form of a venture capitalist of last resort.

Our study has a rather different focus. We take the perspective that the PPP is simultaneously a financing supply shock to small firms and a demand shock for banks, especially in the early stages of the program. Studying the supply shock highlights the fact that even when government funding has desirable features such as low costs, immediate availability, and positive valuation effects, firms are also concerned with its indirect costs. We discuss the nature of these costs. While scrutiny is inevitable when taxpayer funds are involved, its subjective nature can create concerns for firms. We show that such concerns are serious enough that firms give up cheap taxpayer funding and that markets value this release.

Studying the demand shock created by the PPP generates insights into the bank intermediaries that fund PPP loans. We find that larger borrowers access PPP funds sooner, consistent with the priorities of banking intermediaries shaping the delivery of PPP funds. These effects appear to be more prominent in big banks, suggesting that where small borrowers bank matters. We draw lessons for the policy design issues relating to stimulus, the costs of being public and the implications for bank-firm relationships.

\section{B. The Indirect Costs of Being Public}

Research examines the costs of being investigated by the government, although not specifically in the context of government aid in a crisis. Jarrell and Peltzman (1985) investigate FTC investigations into false or misleading advertising and report that the damage to shareholder value goes beyond the direct financial penalties. Alexander (1999) establishes that these penalties arise in a range of violations in government contracts. She estimates that the valuation effects of $-2.26 \%$ are due to reputational losses. See Haslem et al. (2017) for a recent review of this line of research.

A reasonable question is why government investigations cause large losses for firms. One issue is that the investigations tend to be highly disruptive. A first order effect is on managers, whose time must be spent on responding to investigations. Moreover, managers must defend against any personal liability. The overhang can last for a long time and affect their 
employability (Karpoff et al. (2008)). The firm's directors suffer penalties personally as do the other firms that they serve on (Fich and Shivdasani (2007)). These reputational losses reflect (or create) negative real effects on firms (Murphy et al. (2009)).

Disruptions from investigations are especially salient for public firms. As Slutzky (2020) points out, the visibility of public firms opens them to continuous scrutiny from a variety of constituents. Customers, suppliers, and providers of capital could also become more wary of firms undergoing investigation. For example, Chen, Zhu, and Wang (2011) show that in China, bank lending is impacted by fraud. Using DealScan data and a Khwaja and Mian (2008) within-firm estimator, Lin and Paravisini (2011) detect negative effects even for the large firms participating in syndicated lending in the U.S. Monitoring increases and the overall credit supply contracts in their sample. Another concern is piggyback lawsuits against firms or by shareholders against managers either concurrent with or after an investigation.

Armour, Mayer, and Polo (2017) bring to light unique evidence on indirect penalties. They study data from 2001 to 2011 in the UK, in a period when misconduct charges and related financial penalties were made public on the same day. The stock market penalties are nine times the actual fines imposed on companies. In our view, the reputational harm is likely to be high in the PPP, a program set up at a time of widespread economic distress and at a great cost to the American taxpayer. Of particular concern is the subjectivity in the scrutiny process and its very pointed focus on listed firms. It is thus not surprising that firms turn away from PPP funds and that markets value this release.

\section{Data}

\section{A. Identifying PPP Applicants}

We identify publicly listed firms that applied for PPP funds using filings in the EDGAR database maintained by the Securities and Exchange Commission (SEC). ${ }^{4}$ Public companies in the U.S. are required to disclose material events including the entry into a loan contract within four business days of the event. Companies use 8-K's for this purpose but sometimes use the quarterly and annual reports (e.g., 10-Q and 10-K) to do so if these reports happen to be scheduled in this timeframe. These filings are our primary source of PPP loan data.

We download all 8-K, 10-Q, and 10-K filings and related documents filed by public borrowers between January 1, 2020 and August 15, 2020. The latter date is one week after the program's official end date of August 8, 2020 and also accommodates delayed reporting,

\footnotetext{
${ }^{4}$ We do not start our data collection procedure with SBA PPP loan disclosures because of (a) difficulties with matching recipients to financial and stock price data as described later; (b) data on dates of SEC filings, which is needed for computing announcement effects; and (c) they do not identify data on PPP returners.
} 
especially in 10-Q and 10-K filings. The median time from PPP loan grant to announcement is 4 calendar days for 8-K filings and 25 calendar days for other filings types such as 10Qs and 10-Ks. We use a combination of computer code and a manual procedure to search for PPP loans within these filings. The code first searches for keywords such as "Paycheck Protection Program," "PPP," or "CARES Act," in the filings. We then read the filings that contain these keywords to identify the actual PPP applicants. For each identified PPP borrower, we collect data such as the loan size, filing date, and the lender, and scan through related press releases. We follow the same procedure for firms that returned PPP loans.

Our search results in an initial sample of 894 PPP loans provided to 731 PPP borrowers (Table I). For firms that take out multiple PPP loans, e.g., when companies' subsidiaries separately apply for these loans, we treat the earliest date as the application date. Most companies initially report PPP loan grants in 8-Ks (64.1\% of all filings) and the rest are in 10-Qs $(27.2 \%), 10-\mathrm{Ks}$ (4.4\%), and other filing types (4.5\%). Companies may also disclose additional details about PPP loans in 10-Qs or 10-Ks that are filed much later. Most companies (66.1\% of 8-K filers) report PPP loans under "Item 1.01: Entry into a Material Definitive Agreement." About one fifth of the firms report PPP loans under "Item 2.03: Creation of a Direct Financial Obligation or an Obligation under an Off-Balance Sheet Arrangement of a Registrant" (22.2\%). Other items used for PPP loan disclosure are "Item 8.01: Other Events" (6.9\%)," "Item 2.02: Results of Operations and Financial Condition" (2.4\%)," "Item 9.01: Financial Statements and Exhibits" (1.2\%), and "Item 7.01: Regulation FD Disclosure" (1.2\%). On 10-Q and 10-K reports, the overwhelming majority of PPP loan grants are reported in the "Subsequent Events" section (69.4\%).

After matching our sample of PPP borrowers to COMPUSTAT for financial characteristics and excluding financial firms, the usable sample for most cross-sectional tests is about 553 public PPP borrowers. $75.2 \%$ of these firms are penny stocks whose nominal share prices are less than $\$ 5$. As returns for these firms may be unreliable, especially at high frequency, we interact return-based explanatory variables (e.g., volatility, Covid stimulus day returns) with a penny stock dummy variable.

We also attempt to match our PPP borrower sample to the public disclosures by the SBA, noting that borrowers who return SBA funds are not part of its public disclosures. The only firm identifier in the SBA data is company name. In about $25 \%$ of the cases, the SBA-reported and COMPUSTAT or EDGAR names do not match, typically due to borrowings by subsidiaries if parent companies in franchiser-franchisee relationships. We use a fuzzy matching algorithm to identify the three best matches, require exact matching of lender names, and cull the data carefully on a case by case basis. We are left with a small number $(9.6 \%)$ of PPP loan applicants that remain unmatched to the SBA data. Our results 
are robust to including or excluding these firms.

To assess the locus of PPP applicants within the small firm universe, we construct a pool of small firms who did not apply for PPP funds. We identify COMPUSTAT firms with less than 500 disclosed employees excluding financial firms with SIC-2 codes between 60 and 69 or equal to 99 (special purpose acquisition companies) and with non-missing data on the number of employees. The employee numbers are as of the last fiscal year before January 1, 2020 or a previous year if the data are missing. The final non-applicant sample includes 1,600 small firms in COMPUSTAT that did not apply for PPP and depending on data needs, between 553 and 678 applicants. $^{5}$

The pre-Covid characteristics of all firms are from COMPUSTAT. Returns are computed using adjusted stock prices downloaded from Yahoo! Finance. We gather credit ratings data from Standard \& Poor's and Mergent. Distance-to-default data are from NUS RMI Credit Research Initiative. The Fama-French industries come from the Ken French data library. We match PPP borrowers and their subsidiaries to DealScan for one set of tests described later. The data on subsidiaries are from Nexis Uni.

\section{B. Identifying Firms Returning PPP Funds}

We identify 111 PPP borrowers that voluntarily repay PPP loans (henceforth "returners") to the SBA soon after applying for PPP loans. The SBA dataset does not identify these firms. Almost $64.9 \%$ of the returners disclose PPP loan repayments in 8-Ks, while $30.6 \%$ use 10-Qs to disclose this action (4.5\% use other filing types). In most cases, the information pertaining to PPP loan repayments is contained in "Item 9.01: Financial Statements and Exhibits" of 8 -K reports (49.5\% of 8 - $\mathrm{K}$ filings). This information is also disclosed in other 8 -K items such as "Item 2.02: Results of Operations and Financial Condition" (21.5\%), "Item 8.01: Other Events" (9.7\%), "Item 1.02: Termination of a Material Definitive Agreement" (8.6\%), "Item 1.01: Entry into a Material Definitive Agreement" (5.4\%), "Item 2.03: Creation of a Direct Financial Obligation or an Obligation under an Off-Balance Sheet Arrangement of a Registrant" (4.3\%), and "Item 7.01: Regulation FD Disclosure" (3.2\%). On 10-Q reports, PPP loan repayments are reported in the "Subsequent Events" section (59.0\%), "Sources and Uses of Cash" section (10.3\%), under "Other Information" (7.7\%), or under various other sections related to liquidity, debt, and financial condition (23.1\%). Excluding financial companies and requiring matching with other datasets slightly reduces the sample to about 100 firms for the tests involving cross-sectional data and stock returns.

\footnotetext{
${ }^{5}$ Alternative specifications are possible, e.g., including or excluding companies that operate in an industry with 2-digit NAICS equal to 72 and have non-missing employee counts in COMPUSTAT. These variations give similar results.
} 


\section{Basic Stock Market Patterns}

Figure 2, Panel A plots the stock market index since January 1, 2020 through August 15, 2020. The cumulative decline over this period is about 33.92\%. Ding, Levine, Lin, and Xie (2020) detect similar patterns in several markets across the world. The U.S. market decline period in Figure 2 corresponds roughly to the February 3 - March 23, 2020 identified by Fahlenbrach et al. (2020) as the Covid-19 collapse period. The market hit a bottom on March 23, 2020 after stimulus appeared to be stalling in the Senate due to the lack of votes to proceed. The market recovered on the next day, March 24, 2020, the stimulus day, as the procedural roadblocks got cleared ahead of the eventual signing of the bill on March 27, 2020. Panel A also plots the return on a portfolio of PPP-eligible small public firms. These firms is have steeper Covid period declines in their stock returns and slower subsequent recovery.

\section{Applying for PPP Funds}

This section describes the types of listed firms that apply for PPP funds and the related valuation effects, with attention to some econometric issues relating to pandemic period return estimation and adjusting the "bang for the buck" treatment effects for anticipation.

Figure 3 shows that the loan applications in our sample come in waves. The first wave is before April 17, 2020 and depletes the initial $\$ 349$ billion allocated to PPP by the Congress. Applications surge again after fresh capital is authorized. A brief pause occurs around May 8, 2020, the deadline to return funds without review for eligibility. Loan applications resume thereafter and gradually taper off. Figures 4 and Figure 5 display data on loan amounts for all applicants and for early and late applicants centered around April 17, 2020, respectively. We see a pronounced right tail at loan amounts of $\$ 10$ million, which suggests that the program's $\$ 10$ million hard cap is binding for some firms. We also see a decline in the density just above a loan amount of $\$ 2$ million, the cutoff above which the loans are subject to audit. We later analyze firms around this cutoff in greater detail.

Table II shows that the median and mean PPP loan size equal $\$ 1.06$ million and $\$ 2.35$ million, respectively. The median and mean loan amounts equal $4.54 \%$ and $8.61 \%$ of the book value of assets and $3.45 \%(11.99 \%)$ of the market value of equity, respectively. The median (mean) ratio of the loan amount to cash and cash equivalents winsorized at $100 \%$ equals $15.9 \%$ (25.6\%). Thus, PPP loans are economically meaningful relative to the liquidity on hand for our sample firms. 


\section{A. Characteristics of Applicants}

\section{A.1. Industry Patterns}

The SBA uses NAICS industry classifications in its lending operations. We analyze the industry distribution of PPP applicants based on 2-digit NAICS (NAICS-2) codes. We drop firms with NAICs 2 equal to 99, special purpose acquisition firms, 53 PPP applicants from the financial sector, and combine those with 20 or fewer applicants into one bucket. ${ }^{6}$ For comparison, we report application probability data for control firms identified in Section III.

Figure 6 shows that the percentage of applicants varies substantially across sectors. It ranges from lows of $4 \%$ to $5 \%$ in NAICS-2 $=22$ and 48 (utilities, transportation) to upwards of $30 \%$ in NAICS-2 = 31, 33, 51, 54, and 56 (manufacturing; information; professional, scientific, and technical services; administrative and support services or waste management). The probability peaks at $63 \%$ for NAICS-2 $=72$, formally "accommodation and food services." This sector includes chain restaurants such as Denny's and Shake Shack, which are large franchises whose establishments are treated as individual entities for the purposes of PPP application. We exclude these firms in the main analysis but including them does not alter our main conclusions.

We next construct a suite of industry fixed effects with two considerations in mind. One, the industry variables are of economic interest and not just nuisance absorbers of uninteresting heterogeneity. The second is the familiar practical consideration, the size of the dataset, which dictates the number of industry clusters that are populated sufficiently to result in estimable regressions. We identify 4 industry clusters as follows.

Covid Impacted Industries: These firms are in industries negatively impacted by Covid-19 pandemic (Fahlenbrach et al. (2020)) and may be more likely to apply for PPP funding.

Health Sector: On the flip side are firms who plausibly benefit - at least relatively from the Covid-19 pandemic. These are the health, pharma, and biosciences sector firms in Fama-French 49 industries 11, 12, and 13, respectively. Their growth opportunities in bio-threat areas create demand for funding including for PPP. On the other hand, if private capital becomes more available, these firms may be less likely to apply. In particular, if this elevates the probability of a negative finding in an audit, health firms may avoid applying as the firms are supervised by government agencies and apply for government grants, which may be impacted by a negative finding in PPP scrutiny.

High Tech Sector: We identify these as firms with Fama-French-49 industry codes of 35, 36 , or 37 . The firms may see growth opportunities from changes in work habits that result in greater demand for technology. They may also be better able to function remotely than (say)

\footnotetext{
${ }^{6}$ The consolidated sectors have 19 firms from NAICS- $2=11,23,44,45,52,53,61,71$, and 81.
} 
a meatpacking plant. These factors may push the firms to seek PPP funding. Moreover, the concerns about scrutiny may be lesser than those of health sector firms.

Machinery Sector: This includes "heavy industry" firms with Fama-French 49-industry code $=21$ (usually NAICS-2 $=33$ ). These firms have more rigidity on the real side and may thus have greater demand for short-term liquidity.

Figure 6 shows that our industry clusters pick up PPP application patterns. $55.8 \%$ of the 187 firms in Covid-19 industries apply for PPP, about double the full-sample application probability of $30 \%$. In the machinery sector, 21 out of 44 firms (47.7\%) apply, again higher than the baseline odds. The application probability is lower in the health sector, where 179 out of 844 firms apply for PPP loans. We find that 109 out of 274 high tech firms $(39.8 \%)$ apply for PPP funding, again higher than the baseline of $29.77 \%$.

\section{A.2. Financial Characteristics of Applicants: Framework}

The analysis of PPP applicant characteristics comes down to two questions. What types of firms seek funding? Relatedly, what firms are more likely to return PPP funds?

At the first sight, it appears that all firms with less than 500 employees should take PPP funds. Any operating inflexibilities such as restrictions on layoffs imposed by PPP only reduce the forgiveness component. But even without forgiveness a $1 \%$ loan is a bargain for the highly constrained firms in our sample. Likewise, some firms may be able to access external finance but this too does not justify not taking PPP funding. The direct cost of PPP is always lower, especially so in the difficult economic environment of the pandemic.

This brings us to the indirect costs of PPP financing, those arising out of government scrutiny that we have discussed before. The indirect costs are likely more relevant for the larger, stronger, less financially constrained firms and those such as health sector firms with better growth prospects after the onset of Covid. This is because the chances of scrutiny and a determination of ineligibility are higher for such firms. Thus, they should be less likely to apply for PPP funds - and more likely to return them. On the flip side, the larger, financially stronger firms should find it easier to raise capital if the SBA demands the return of PPP funds. If so, these firms should be more likely to apply for PPP funds. Which effect matters is an empirical issue.

Another reason for not taking or for returning already-taken PPP funds is that taking PPP funds could affect eligibility for other benefits. ${ }^{7}$ Press reports attest to the seriousness

\footnotetext{
${ }^{7}$ For individuals, the April 20, 2020 guidance says that PPP impacts the state-administered unemployment compensation or unemployment assistance programs. See https://www.federalregister.gov/document s/2020/04/20/2020-08257/business-loan-program-temporary-changes-paycheck-protection-pr ogram-additional-eligibility-criteria. Such programs include others in the CARES Act including those authorized by Title II, Subtitle A of the CARES Act, or CARES Act Employee Retention Credits.
} 
of these concerns for firms. For example, government contractors may be shut out of future business, face rate cuts under Federal Acquisition Regulation rules that count forgiveness against payments for future work, face charges of double dipping for future government work, or face adverse publicity in the event of negative determination of PPP eligibility. ${ }^{8}$ Firms that must interact more with the government agencies, such as drug companies that seek approvals, should be less likely to take PPP funds.

\section{A.3. Financial Characteristics of Applicants: Results}

Table II reports characteristics of PPP loan applicants as well as those of the pool of COMPUSTAT firms with less than 500 reported employees. The $p$-values are based on Wilcoxon rank-sum tests as many variables are highly skewed. Briefly, the data show that PPP firms are smaller, more constrained, and weaker even relative to the other small firms.

Panel A of Table II shows that PPP applicants are small in an absolute sense and relative to other small firms with less than 500 employees. The mean (median) book value of assets and market value of equity of applicants is $\$ 109.3$ million ( $\$ 34.8$ million) and $\$ 102.6$ million (\$35.4 million), respectively. This places the firms in the smallest decile of the Fama-French cutoffs for firm size based on market capitalization. Even within this pool, applicants appear to be smaller. Non-applicants have mean (median) book and market values of $\$ 482$ million (\$74.3 million), and $\$ 446.7$ million (\$102.5 million), respectively. Other size metrics such as sales and the number of employees show the same pattern. ${ }^{9}$

The mean (median) age of PPP applicants equals 16 years (12 years) and 10.1 years (7 years), respectively. PPP applicants are smaller but have been established for longer relative to other small firms. The growth characteristics of the PPP firms resemble those of small firms, viz., Tobin's Q $>1.0$, high sales growth, and low proportions of dividend payers.

PPP applicants appear to have less liquidity and less financing access relative to the small firm pool. The mean (median) current ratio of 2.562 (1.616) is lower than that of other small firms as is the ratio of cash to non-cash assets of 1.05 (0.22) for these firms. With regard to financing access, one indicator is whether a firm has a credit rating (Faulkender and Petersen (2006)). Panel C of Table II shows that only about $2 \%$ of applicants are rated, about half of the (still low) rate of $4.8 \%$ for non-applicants. PPP firms are highly constrained according to indexes commonly used in finance research. A high $71.78 \%$ of the PPP applicants fall into the top quartile of constrained firms according to the Whited and Wu (2006) (WW)

\footnotetext{
${ }^{8}$ See, e.g., PPP Loans: Why Some Government Contractors Are Returning the Money, The Wall Street Journal, August 9, 2020.

${ }^{9}$ We note here that the results are conservative. The COMPUSTAT-disclosed number of employees for PPP firms is sometimes more than 500. For example, PPP eligibility for hotels is based on employees in an establishment but COMPUSTAT reports the total employment count.
} 
constraints index. $77.2 \%$ are in the most constrained quartile based on the Hadlock and Pierce (2010) SA constraints index. ${ }^{10}$ It is important to note that the patterns are prior to the pandemic - and not caused by it.

The relative weakness of PPP applicants is also evident in indicators of distress risk. 9.8\% of PPP applicants have zero debt, which is somewhat lower than the $15.3 \%$ for nonapplicants (Korteweg (2010); Strebulaev and Yang (2013)). Applicants have modest mean (median) leverage of $25.9 \%$ (17.8\%), similar to non-applicants, but their low interest coverage ratio shows that PPP firms struggle more to service similar levels of debt. Specifically, 80\% of PPP firms cannot cover interest 1.5 times. Even fewer can cover interest 2.5 times, which is a benchmark for large investment grade companies.

The Altman (1968) Z-score and the distance to default show similar patterns. The vast majority (69.6\%) of PPP applicants have Altman Z-scores below 1.81, a benchmark for high default risk. PPP applicants also have lower distance to default (Bharath and Shumway (2008); Duan, Wang, et al. (2012)) than the overall small firm pool. Following Seguin and Smoller (1997), low nominal prices indicate greater mortality. ${ }^{11}$ Over $75 \%$ of applicants are penny stocks, higher than the $61 \%$ for non-applicants.

In sum PPP applicants are smaller, weaker, more constrained, and have less liquidity than typical small firms even before the pandemic. How does the pandemic impact them? The data provide little cause for optimism. Figure 2 shows that PPP applicants have lower average cumulative buy-and-hold abnormal returns (BHARs) from January 1, 2020 to March 23, 2020, the day before the passage of the CARES Act. Table II shows that applicants did not do better in terms of returns from February 3, 2020 to March 23, 2020, the Covid period s defined in Fahlenbrach et al. (2020). On March 24, 2020, the stock market records a positive jump, responding to the news on the imminent passage of the CARES Act. The mean market-adjusted return on this day for PPP applicants is $5.6 \%$, similar to the $5.8 \%$ mean for non-applicants. There is little evidence that PPP firms benefitted especially from the overall CARES stimulus program.

We complete the characterization of PPP applicants by estimating multivariate regressions that explain the characteristics of PPP applicants relative to the pool of small COMPUSTAT non-applicants with less than 500 employees after exclusions such as financials. Table III reports the estimates of several specifications without and then with controls for

\footnotetext{
${ }^{10}$ These studies update the earlier work of Kaplan and Zingales (1997). Hoberg and Maksimovic (2015) provides an index based on textual data but is not updated for the recent periods. Size is an important driver of both the WW and SA indexes. Small firms are more constrained.The SA index counts young firms are more constrained, which mutes the differences between PPP applicants, who are older, and the remaining firms in the small firm pool.

${ }^{11}$ See also the SEC guidance on penny stocks, available at https://www.sec.gov/fast-answers/answe rspennyhtm.html, which argues that these stocks are risky.
} 
industry, Covid period returns, and CARES stimulus day returns. The return variables are interacted with a penny stock dummy variable to account for noise in price data due to price discreteness and market illiquidity of penny stocks. The regression results indicate that applicants are smaller, older, slower growing and have less liquidity.

The economic magnitudes are sizable. For example, a one standard deviation increase in the natural logarithm of assets decreases the probability of applying for PPP by at least 5.30 percentage points (pp), or by $20.63 \%$ relative to the unconditional mean. The respective magnitude for the current ratio is $3.85 \mathrm{pp}$, or $15.00 \%$. The results are similar when we restrict our analysis to microcaps, which are firms with at least $\$ 50$ million in market capitalization in COMPUSTAT (Internet Appendix, Table IA.B.1). In Table IV, we find that highly constrained firms according to the Whited-Wu constraints index are more likely to borrow. ${ }^{12}$

The data paint a clear picture of the types of firms that apply for PPP. The applicants are typical of small firms in some respects and where there are differences, the PPP applicants appear to be weaker: smaller, less liquid, more constrained, and with greater distress risk. An important point is that these differences are prior to the onset of the Covid pandemic. Thus PPP applicants were not particularly strong entering into Covid and there is little evidence that they were strong performers during the Covid period.

\section{B. PPP Application Announcement Effects}

As discussed earlier, the Covid-19 pandemic has had a multitude of effects on demand and supply. These offer many intervention targets for policy but also make it challenging to assess the impact of individual policies in isolation. We contribute evidence on stock market valuation effects related to PPP. Using filings data, we are able to pinpoint a plausible window of dates when the market learns about a firm's PPP application, when its share prices react and impound its treatment effects. We make econometric corrections for clustering, firm-level heterogeneity, and cross-sectionally varying partial anticipation.

We assume that the market learns that a firm has applied for PPP funds on the filing date of the relevant disclosure. To account for event date uncertainty, we consider returns over windows bracketing the application date. Figure 7 shows CARs (cumulative abnormal returns) in event time for a large window of 10 days, viz., [-5, 5] where [0] denotes the filing date. The average CAR is over $5 \%$ in the time interval $[-5,1]$, much of it in $[-3,1]$. From Panel B, the results are similar for both market adjusted or market model abnormal returns.

Table $\mathrm{V}$ focuses on a narrow $[-1,+1]$ window to be more conservative in isolating PPPrelated returns. We use a regression specification in which the dependent variable is the

\footnotetext{
${ }^{12}$ We report this regression separately rather than adding constraint indexes to Table III because many variables that go into the index are already included individually.
} 
daily abnormal return (using market-adjusted or market model returns) from January 1, 2020 until the event date plus one day. The independent variables of interest are the three dummy variables representing the filing date and this date plus or minus one day. The focus on daily abnormal returns in the pandemic period but not before is conservative. It addresses the point in prior research that pandemic period returns are unusual. Our estimates are within the pandemic period and do not reflect any differences between the pandemic and pre-pandemic periods. We include firm fixed effects, which absorb firm-level heterogeneity within the pandemic period. Finally, we account for the possible bunching of PPP applications in waves (Figure 3) by clustering standard errors by calendar dates.

We report three estimates, one for all PPP applicants, another for PPP applicants keeping only those using 8-Ks to announce loan applications, and finally, a sample that excludes penny stocks. For the full sample, Panel A shows that the PPP abnormal returns are positive and are roughly equal to $1.0 \%$ for both methods of estimating abnormal returns. The returns appear to accrue on day [-1]. The estimates increase to about $1.5 \%$ when we narrow down the sample to firms announcing through 8-K's, which is not surprising given that 10-Q announcements contain other information and thus add noise to the PPP-related release. More precise estimates (as evidenced by narrower standard errors) based on 8-K's are also consistent with Heitz, Narayanamoorthy, and Zekhnini (2020) who find that most earnings information seems to be reflected in 8-K's ahead of the actual earnings announcements in regular reports (e.g., 10-Qs and $10-\mathrm{Ks}$ ). Excluding penny stocks has no material impact on the results. The announcement effects are somewhat greater for the larger firms with at least $\$ 50$ million in market capitalization (Internet Appendix, Table IA.B.3). There is little evidence that taking PPP funds harms shareholders. In fact, shareholders appear to benefit from taking PPP funds.

\section{Bang for the Buck Treatment Effects}

We next consider the estimation of "bang for the buck" treatment effects for PPP funding. A simple baseline is the hypothesis that a $\$ 1$ subsidy given to firms should result in a $\$ 1$ gain to shareholders. If the PPP funds are passed through to employees or used for other eligible expenses, shareholders save on the internal resources the firms would otherwise use.

The average change in the dollar market value of a PPP applicant is $\$ 3.35$ million. Across all the $541 \mathrm{PPP}$ borrowers for which we can compute this change, the total change in value is $\$ 1.82$ billion. As the total PPP loan amount for these firms equals $\$ 1.53$ billion, the PPP bang for the buck equals $\$ 1.82$ billion $\div \$ 1.53$ billion $=1.19$. The estimate is skewed by one large borrower, AutoNation that takes $\$ 77$ million in PPP loans and has about 10 times 
the amount as shareholder gain. If we exclude this firm, shareholders gain $\$ 1.04$ billion and take in PPP funds of $\$ 1.45$ billion for a 0.72 bang for the buck. That is, $\$ 1$ in PPP funds increases share value 72 cents, less than $\$ 1$.

We identify 129 PPP firms that are not penny stocks. This sample includes the larger and financially stronger firms. These firms gain $\$ 908$ million and take $\$ 538$ million, giving a bang-for-buck of about 1.69. The remaining 411 penny stocks take $\$ 914$ million in PPP loans and have an increase in market capitalization of $\$ 131$ million, giving a bang for the buck of just 0.14. Thus, within the universe of small listed firms, the bang for the PPP buck is greater for the larger and stronger firms.

\section{Partial Anticipation Corrected Treatment Effects}

Announcement date returns are less than the actual changes due to an event if the event is partially anticipated. Thus, the bang for the buck based on the announcement-date return may be attenuated because some part of the treatment effect is anticipated and built into the pre-announcement share prices. Correcting for anticipation requires us to scale up the announcement returns by a factor related to the probability of PPP application (Acharya (1988); Eckbo, Maksimovic, and Williams (1990); Prabhala (1997)).

Suppose $q_{f}$ is the probability assessed by the market that firm $f$ applies for a PPP loan. Let the benefit of the PPP be $B$. On the date the market learns that firm $f$ has applied for PPP funds, the change in its value, say $D$, equals $\left(1-q_{f}\right) B$. Thus, the actual benefit

$B$ equals $\frac{D}{1-q_{f}}$ and the aggregate across all firms is $\sum_{f} \frac{D}{1-q_{f}}$. An estimate of $q_{f}$, the ex-ante probability of applying for PPP, comes from the estimates in Table III. It is difficult to compare the uncorrected and anticipation-corrected aggregate estimates. For instance, if smaller firms are more likely to apply for PPP, the dollar changes on the announcement date for these firms will be scaled up more than for the larger firms.

We use the predicted values from the regression for the PPP applicants with $1 \%$ winsorization to re-estimate the adjusted bang for the buck treatment effects. The essential patterns in the data remain intact. The anticipation-corrected treatment effect of the PPP program equals $\$ 1,572$ million, which is equal to $108 \%$ of the aggregate PPP loan amount for the 540 borrowers excluding AutoNation. For penny stocks, the bang for the buck is 0.40 , reflecting gains of $\$ 338$ million versus loan amounts of $\$ 850$ million. For non-penny stocks, it is 2.05, with shareholder gains and PPP loan amounts of $\$ 1,233$ million and $\$ 601$ million. As before, the larger, stronger PPP applicants produce a greater bang for the PPP buck. 


\section{E. Economics of the Estimates}

How useful are the stock market data in understanding the PPP program? We briefly discuss the merits and limitations of the analysis next.

One issue is that the PPP is announced as a $\$ 669$ billion part of the $\$ 2$ trillion CARES Act package that has other forms of stimulus. The other pieces of the CARES Act can be confounders in interpreting PPP effects. Our experiment design somewhat mitigates these concerns. We focus on PPP applicants only and on disjoint dates when markets learn about a PPP application. These dates are spaced away from the CARES Act announcement date and also staggered cross-sectionally across firms, letting us isolate PPP effects. Finally, the totality of the CARES package is perhaps reflected in (and thus contaminates) the aggregate stock market but the market is stripped out when we compute abnormal returns in the firm fixed effect models that we estimate.

A related issue is about the externalities of the PPP itself. Once again, we note that our outcomes are firm-specific effects that strip out the broad market-wide effects of the PPP. One estimate of the marketwide effects is perhaps the market's reaction to the PPP announcement on March 24, 2020. The aggregate return equals $9.38 \%$ for the market (S\&P 500 Index). Of course, interpreting this estimate as being due to the PPP alone is implausible given that the PPP is embedded in the larger CARES Act fiscal package.

A third point is whether share prices are the right metric to assess the PPP outcomes. Shareholder value may be subordinate or collateral outcomes relative to jobs or wages. This viewpoint is certainly reasonable. But shareholder value is not entirely without use. The PPP was designed to keep enterprises running and is more impactful when business owners experience its positive effects.

A final point related to real-time economic tracking, a focus of the economics literature particularly in the wake of the pandemic (see Chetty et al. (2020)) but also in other areas such as nowcasting macroeconomic data. The stock market responses are in fact a real-time assessment of the program effects that incorporate information known market about the PPP application and its assessment of PPP effects.

We note that it is tempting - and certainly easy - to use our estimates to extrapolate the bang for the buck for the entire PPP disbursement of $\$ 525$ billion. This extrapolation does not seem appropriate. Non-traded firms that are overwhelmingly the primary targets of PPP and many of these firms have simply no analog in the public space, e.g., private schools or not-for-profit organizations. The implication for the larger mass of private firms is perhaps that even in the universe of public firms, the bang for the buck is small and concentrates in the larger and stronger subset of firms. 


\section{Returners and PPP Return Valuation Effects}

Several firms that obtained PPP loans returned the funds within a short period of time before using the funds. We analyze the decision to return PPP funds and the associated announcement effects. The main tradeoff has been discussed before. Firms give up PPP funding to save on the indirect costs of taking PPP funding. These costs arise from the reputational losses from a possible negative determination in a government investigation of PPP recipients, especially in light of the subjective guidance on investigations that moreover appears to target public firms. These investigations can disrupt firms and their key personnel, creating losses beyond any direct penalties and thus aversion to PPP funding. ${ }^{13}$

Reputational concerns should be more important for the larger, more profitable firms in which investigation-related distractions are costlier. Moreover, firms with access to liquid resources should be more willing to forgo PPP funds as these firms can raise alternative sources of funding. Finally, firms subject to more interactions with and oversight of the government and regulators should be more likely to return PPP funds. We test these propositions.

\section{A. Univariate Statistics}

Table VI reports the characteristics of 104 firms that returned PPP loans - henceforth "returners." Alongside, we report the characteristics of the 574 firms that did not return PPP funds - henceforth "retainers." The mean (median) loan amount for PPP returners equals $\$ 4.58$ million ( $\$ 3.54$ million) compared to $\$ 1.95$ million $(\$ 0.9$ million) for retainers. Firms that return PPP money had applied for larger loan amounts.

Turning to the other characteristics of PPP returners, the overall flavor of the results is that retainers are smaller and financially weaker ex-ante even before the Covid pandemic. The mean (median) book value of assets for the returners equals $\$ 299.2$ million ( $\$ 87$ million) compared to $\$ 67.4$ million (\$28.4 million) for the retainers. Table VI shows that the difference is significant. We see similar differences in other size characteristics including market capitalization, sales, and the number of employees. Returners are less likely to have negative book value, higher Tobin's Q, higher sales growth, and are more likely to pay dividends (22.1\% versus $12.5 \%$ for retainers).

Returners have better liquidity with higher current ratios, cash balances, and are more likely to be rated ( $6.7 \%$ versus $1.4 \%$ for retainers) although access to public debt is overall low, as typical for small firms. Returners are also less financially constrained per the Whited-

\footnotetext{
${ }^{13}$ See, e.g., "Spotting the $\$ 62$ million in alleged PPP fraud was the easy part"' https://www.nytimes.co m/2020/08/28/business/ppp-small-business-fraud-coronavirus.html. Berk, Stanton, and Zechner (2010) discuss managerial aversion to bankruptcy-like events.
} 
Wu and the Hadlock-Pierce SA indexes, have greater distances to default, lower Altman Z scores, and are less likely to be penny stocks compared to retainers. Returners are clearly stronger financially even before the pandemic period.

We also examine industry patterns. Around $22 \%$ of health sector firms return PPP funds compared to $13 \%$ of non-health firms, in contrast, only $10 \%$ of high-tech firms return PPP funds compared to $16.3 \%$ of firms in non- high-tech industries. While both industries faced better prospects in the pandemic, the health firms have greater regulatory interactions and

are less likely to keep PPP funds and face the prospect of e negative investigation. Only $9 \%$ of the firms in industries impacted by the Covid return PPP funds compared to $16.72 \%$ in non-Covid industries. Likewise, only $10 \%$ of machinery industry firms return PPP funds compared to $15.52 \%$ of firms that are not in the machinery sector. Thus, firms with greater demand for funds and more prone to distress from illiquidity are less likely to return funds.

We do not find evidence that returners benefit less from PPP stimulus. The mean (median) stimulus day return of PPP returners equals $7.1 \%$ (6.2\%) compared to 5.3\% (3.5\%) for retainers. The data show that the Covid period returns and the PPP loan announcement effects are similar for the two samples. Returners have a higher PPP application bang for the buck, 0.87 versus 0.65 for the retainers. Little in these patterns suggests that firms that return PPP funds are the ones that had benefitted less from PPP.

\section{B. Multivariate Results}

Table VII reports estimates of regressions that model the decision to return PPP loans. In the sample are $530 \mathrm{PPP}$ firms with sufficient data. As in the univariate results, large firms are more likely to return PPP funds. A one standard deviation increase in the natural logarithm of assets increases the probability of returning the PPP loan by at least 8.43 pp, or by $46.61 \%$ relative to the unconditional mean. This result also holds for firms with at least $\$ 50$ million in market capitalization (Internet Appendix, Table IA.B.4). In fact, unconditionally, firms in the $\$ 50$ million plus microcap range are 4.6 times more likely to return PPP loans than the (even) smaller public firms. Growth firms are also more likely to return PPP funds, as are firms with higher current ratios.

An interesting and very robust finding is that penny stock firms are less likely to return PPP funds. As discussed earlier, research (e.g., Seguin and Smoller (1997)) suggests that penny stocks face greater failure hazard, and given their classification as speculative investments, face greater hurdles on capital raising. We find that these firms are more likely to retain PPP funds. As in the univariate results, machinery firms that face more real-side rigidities are less likely to return PPP funds, health sector firms are more likely to return 
PPP funds. These firms enjoy better growth prospects and have greater incentives to avoid investigations that negatively impact their other interactions with the government agencies.

Specification (3) includes stock return data. We find that firms with better Covid period returns tend to return PPP funds. Table VIII shows that less constrained firms, as evidenced by both the WW and the SA indexes, are more likely to return PPP funds. Low bankruptcy risk firms with Altman's Z-score $>1.81$ are more likely to return PPP funds. Internet Appendix (Tables IA.B.2 and IA.B.5) show similar patterns with distance to default. Collectively, these findings add to the basic thrust of the main finding that the act of returning funds by PPP firms is more likely in the better quality applicants for PPP.

\section{Announcement Effects Related to PPP Loan Return}

We next turn to the announcement effects relating to the return of PPP loans. We display the cumulative abnormal returns (CARs) in starting from date $t=-5$, where $t=0$ denotes the filing date of the disclosing 8-K. In Figure 11, we find that PPP return dates spike in early May 2020, when the SBA clarified that firms returning funds early would not be audited. subject to audit. Figure 12 shows that the announcement effects are positive for both the market-adjusted and the market model abnormal returns.

Table X reports the estimates of a fixed effects regression of the abnormal return on date dummy variables that are non-zero in $[-1,+1]$ where $[0]$ is the 8 -K filing date and the sample includes returns in $[-60,+1]$. We cluster returns by calendar date. The announcement effect is about $+3 \%$ regardless of specification. Table IA.B.6 in the Internet Appendix shows similar results for the larger microcaps in our sample with value of at least $\$ 50$ million. ${ }^{14}$

What factors other than indirect costs could explain the positive PPP loan return announcement effects? One possibility is that there is a signal that returners gained access to alternative sources of funds. Equity financing is one possible source but equity issuance traditionally sends a negative signal to the market. A better candidate is bank lending, whose announcements trigger positive announcement effects (James (1987); Lummer and McConnell (1989); Billett, Flannery, and Garfinkel (1995); Chen, Ho, and Liu (2019)). This interpretation, if correct, reinforces our point concerning government scrutiny. That is, monitoring or scrutiny by the government is less valuable compared to monitoring by private providers of capital, which can outweigh the higher costs of the latter.

We consider treatment effects akin to those for announcement effects. The average change in value is $\$ 13.41$ million and the total is $\$ 1,341$ million across all returners. Once again, a

\footnotetext{
${ }^{14} \mathrm{~A}$ small number of firms (about a half-dozen) indicate in their 8-K disclosures that their performance has improved so they returned PPP funds. While return is still not optimal, excluding these firms have no effect on the results. We leave the analysis of specific performance improvements for the future.
} 
single observation, AutoNation drives over half of this effect. Excluding this outlier results in an average change in value of $\$ 5.76$ million, with the total of $\$ 564$ million across all borrowers. We add to that the amount of the loan returned, $\$ 557$ million, which should (under the null of a pure pass through or transfer of wealth to the government) result in a negative change of $\$ 557$ million. Thus, the actual change in wealth relative to the counterfactual of a pure pass through is $\$ 1,211$ million.

As before, we can correct announcement effects for partial anticipation by scaling them for the portion impounded in the pre-announcement share price, which is $(1-q)$ where $q$ is the probability that the funds are returned. Doing so using the probability model estimated in Table X - and excluding AutoNation - shows that anticipation-corrected net gain is $\$ 1,805$ million. Returning $\$ 557$ million should have resulted in losses of $\$ 557$ million to the returners but instead this turns into a gain of $\$ 1,805$ million or about $8.50 \%$ of firm value.

\section{Discontinuity in Treatment}

We consider an exogenous discontinuity created by SBA rules concerning the probability of being investigated. The interim final rule issued by SBA in the Federal Register on June 1, 2020 says that all loans are subject to audit. However, both the Treasury and the SBA have indicated that firms with loans less than $\$ 2$ million will be presumed to have applied in good faith, creating a discontinuity in the investigation risk and indirect costs at this cutoff. We assess whether it impacts the decision to return PPP funds.

While the returner sample is small, univariate statistics indicate that the $\$ 2$ million discontinuity matters. The sample odds of returning PPP funds are only $7 \%$ for loan amounts of $\$ 1.5-\$ 2$ million but triple to $21 \%$ for loan amounts between $\$ 2-\$ 2.5$ million (Figure 10 ). Relatedly, $8.39 \%$ of the 453 firms with loan amounts less than $\$ 2$ million returned PPP funds, while $29.5 \%$ of the 224 firms with loan amounts more than $\$ 2$ million did so. We next consider regressions with the forcing variable as the loan amount and a discontinuity at $\$ 2$ million. The key issue is the small sample size of 104 returners, which reduces the power of local designs using small windows around $\$ 2$ million. To increase power, we use a global approach that uses all firms. Table IX gives the results.

Panel A presents the results for 4 specifications without firm controls. The coefficient for the indicator variable for the PPP loan amount of $\$ 2+$ million is positive and significant. The probability of PPP loan repayment increases by $8.45 \%$ to $14.9 \%$ when firms borrow $\$ 2$ million and above. This estimate is the marginal effect of borrowing above the discontinuity threshold beyond the effect of PPP loan size as captured by the distance between the PPP loan amount and $\$ 2$ million. The coefficients remain positive but with reduced significance 
when we incorporate the full set of controls in Panel B. For completeness, we show results with a narrow window around $\$ 2$ million in Panel $\mathrm{C}$. The results in the narrow bandwidth specifications lack power due to the small number of observations.

\section{Early Applicants and Lender Effects}

As discussed before (e.g., Figure 3), PPP applications come in two waves. The first wave followed the initial PPP allocation of $\$ 349$ billion before April 17, 2020 (PPP Round 1). The second wave occurred after the PPP funds replenishment on May 27, 2020 (PPP Round 2). We analyze the differences between the two sets of firms. Firms could be served early because of their demand for early funding. Alternatively, the supply-side incentives of the bank intermediaries making the PPP loans can determine the firms gaining early access.

From the demand viewpoint, if small and weak firms are more distressed and constrained, they should constitute the majority of the early applicants. Similar predictions are produced by an option to wait feature. The PPP funds must be used within short periods of time for maximizing forgiveness. Firms are better off waiting to let demand recover instead of taking funds and incurring expenses when demand is low. Optionality is also introduced by changing program rules that have leaned towards a more relaxed regime. These arguments suggest that large firms could delay taking PPP funds. Waiting is neither feasible nor optimal for small, weak firms likely to go out of business before exercising the option to wait.

For the supply side, we consider the role of bank intermediaries deliver the PPP funds. Firms must apply for PPP funds through banks. In the early stages of the program, the bank lenders faced a shock in demand due to two reasons. One is the surge in the number of applications, which overwhelmed banking capacity to process loan applications. A second reason was that the PPP funds pool was running out. Banks were forced to decide how to prioritize their resources across different types of applicants.

Lenders face two incentives. One incentive is related to lender fees. PPP's fee structure makes it more profitable to process larger loans. This is because the cost of application processing is relatively fixed and fees are a percentage of loan proceeds. Thus, lender fee income is increasing in PPP loan size, especially in very large loan sizes. ${ }^{15}$ Firm size can also matter, for example, large borrowers have more sub-entities that can apply for several loans at the same time. Larger and better quality firms can also produce future revenues such as those from cross-selling other services,

\footnotetext{
${ }^{15}$ Larger loans are more profitable within percentage fee buckets but there is some non-monotonicity because the percentage of amount paid as fee decreases with loan size bucket. For instance, loan amounts must be above $\$ 585,000$ to be more profitable than a loan of $\$ 350,000$ but neither is more profitable as a loan of $\$ 5$ million.
} 
Thus, if lender-related supply side effects matter, larger and better quality firms should be prioritized over smaller, distressed, illiquid clients in the early stages of the program. Moreover, if these incentives vary across small and big banks, we should see differences between big and small banks in the distribution of small firms in the early versus late stages. Our analysis in this section is organized on these lines.

\section{A. Large Firms Gain Early PPP Access}

Table XI reports baseline data characteristics discussed in the previous sections for the 431 early and 231 late applicants under the PPP program. PPP loan amounts are greater for early applicants at mean (median) of $\$ 2.566$ (\$1.384) million compared to $\$ 1.912$ (\$0.70) million for later applicants. Firms requiring larger loans go earlier, which is one indicator of intermediary supply side effects at play in determining which firms get early PPP access.

Table XI also reports data on a number of financial characteristics of borrowers. A size effect is quite evident in the data patterns. Early applicants are larger in terms of book value of assets, the market value of assets, sales, and employment. Among other characteristics, we find that early borrowers are less likely to have negative book value, have higher Tobin's $Q$, are more likely to pay dividends, and have greater current ratios. These are traits of better quality firms. Once again, the patterns are not consistent with demand-side explanations under which the weaker, the more distressed, and the more constrained firms go early. The multivariate regressions reported in Table XII show similar patterns. Firm size has a positive and significant coefficient across all specifications.

We consider the possibility that larger firms may find it easier to navigate the application process early as they have better organized administrative capabilities. This is perhaps plausible in the larger universe of all PPP applicants, which include entities such as tiny corner stores or proprietorships. However, here too, we note that the PPP design deliberately simplifies the documentation needs to what should be fairly routine. In any event, the key point

is that the results in this section pertain to listed firms. These firms already comply with periodic disclosure requirements that are far more substantive than the PPP requirements. Thus, the results presented here are more consistent with intermediary incentives shaping PPP funds supply in the early stages of the program. We expand on this point further.

\section{B. Big Banks versus Small Banks}

The result that larger firms are more likely to receive early access to PPP is consistent with the idea that financial intermediaries matter - banks shape the delivery of PPP benefits. We now turn to the question of whether the bank effects exist in big and small banks. As 
our sample comprises small firms, any differences between big and small banks - or the lack thereof - speak to the role of the two types of banks in small business lending.

Research suggests that smaller firms benefit more from relationships with small banks as soft information matters in lending. For an early theory, see Stein (2002) and for empirical evidence, see Berger et al. (2005). The 2018 FDIC Small Business Lending Survey reports related findings. ${ }^{16}$ As the survey indicates, small banks define their lending trade areas locally, do not view nationalized banks as their rivals, are more flexible in understanding and qualifying small businesses for lending (e.g., owner characteristics and localness of business), and are relationship oriented. The strength of small banks is small business lending. ${ }^{17}$

In contrast, soft information can be "hardened" more for the larger firms, pushing them towards larger banks that rely on hard information lending technologies. Moreover, larger banks have other strengths such as the quantum of funds relative to firms' needs, one-stop shopping for many services, or local and international branches that are more relevant for larger firms. As the FDIC Small Business Lending Survey notes, large banks are perceived to be transactional and stress their broad networks and professional referrals as strengths.

We thus test the hypothesis that the tilt towards larger customers in the PPP is more pronounced in the big banks rather than the smaller ones. At times when banks have limited capacity and must prioritize their most valuable customers, big banks may favor larger clients more than small firms. If true, a small firm can be at a disadvantage being with a large bank as opposed to being with a small bank, particularly in disruptive times when bank capacity is stretched. This is different from - but complementary to - the soft information arguments for why small borrowers tend to stay with small banks. Whether we can detect this pattern in the data or not is the question we turn to.

Our tests need a definition of a big bank. Our classification is based on whether a bank belongs to the top 10 banks by asset size in the U.S. The big-10 banks provide $\$ 452$ million in PPP funding in our sample of public firms while $\$ 1.3$ billion comes from smaller (non-big-10) lenders. The smaller banks provide $\$ 971.4$ million in funding in PPP Round 1 (or $75.6 \%$ of PPP Round 1 funding of $\$ 1.28$ billion) and $\$ 346.1$ million in funding in PPP Round 2 (or $70.7 \%$ of PPP Round 2 funding of $\$ 489.5$ million). The smaller lenders serve a larger share of their publicly listed PPP customers early compared to big-10 banks. Smaller banks provide loans to $69.1 \%$ of their PPP customers in PPP Round 1, whereas big-10 banks provide loans to $52.9 \%$ of their PPP customers in PPP Round 1.

Table XIII reports the data for early versus late PPP borrowers cross-classified by lender

\footnotetext{
${ }^{16}$ See https://www.fdic.gov/bank/historical/sbls/full-survey.pdf.

${ }^{17}$ Petersen and Rajan (1994); Berger and Udell (1995) show that firms value bank relationships. Drucker and Puri (2005), Bharath, Dahiya, Saunders, and Srinivasan (2007), discuss their value to banks.
} 
type. There are significant differences in the average firm size (Panel A) and PPP loan size (Panel B) between the two PPP rounds for big-10 banks. The mean asset size of big-10 bank clients is $\$ 144.2$ million for early PPP borrowers versus $\$ 62.4$ million for late PPP borrowers. The difference is statistically significant at the $1 \%$ level. The results are not quite the same for the smaller banks, whose publicly listed customers are on average a little larger in the later round and the difference is no longer significant.

Similarly, the average size of PPP loans appears to be larger for PPP clients of big10 banks that borrow early compared to clients that borrow late, at $\$ 3.4$ million and $\$ 1.8$ million, respectively. Again, the difference is statistically significant at the $1 \%$ level. While these numbers for smaller bank clients, $\$ 2.5$ million versus $\$ 2.2$ million, point in the same direction as for big-10 banks, the difference is noticeably smaller than for big-10 banks. In Appendix B, Table B.1, we consider a more granular classification of lender types into four buckets and find that the disparity in size between early and late loans continue to be greater for the biggest banks. The patterns are robust across different measures of firm size, including the number of firms' employees (Internet Appendix, Table IA.A.1), and hold in regression settings (Internet Appendix, Table IA.A.2).

In our view, the early-late differences in average borrower size (or loan size) between big and small banks are best viewed as one implication of the differential prioritization of small customers across banks. We consider ways to strengthen the findings. One possibility is to look at the entire pool of all customers at the bank and test how the entire distribution of firm size across the two types of banks. A greater leftward shift in the density of PPP customers in the later period would indicate a greater propensity of banks to shift smaller customers towards later periods, or equivalently, the prioritization of large customers early.

Figure 13 depicts the densities of firm size for big-10 and smaller banks for the early and late periods. We observe a more significant shift in the density for big banks, consistent with supply effects being more prominent for these banks. The patterns are similar for the cumulative distributions (not reported). Two-sample Kolmogorov-Smirnov tests for the equality of distribution functions for the natural logarithm of firm assets between early and late PPP borrowers return the combined D statistic of 0.3248 for big-10 banks (exact $p$ value $<0.001$ ) and 0.1275 for smaller banks (exact $p$-value $=0.204$ ). These results indicate larger statistically significant differences in firm size distributions between the two PPP rounds for big-10 banks. For these larger banks, late PPP borrowers are more likely to include firms with smaller assets $(\mathrm{D}=0.3248$, $p$-value $<0.001)$ whereas early PPP borrowers are less likely to include firms with smaller assets $(\mathrm{D}=-0.0012, p$-value $=1.000)$. There are no discernible unidirectional differences in distributions for smaller banks based on the Kolmogorov-Smirnov test. 
Figure 14 depicts the densities for the loan (rather than firm) size. The differences appear as stark as for firm size, with a slight shift in PPP loan size between the two PPP rounds for small banks but a pronounced tilt toward larger PPP loans early in the PPP for the larger banks. We obtain similar results from Kolmogorov-Smirnov tests for the natural logarithm of PPP loan size. The combined D statistic is 0.3066 for big-10 banks (exact $p$-value $<0.001$ ) and 0.1574 for smaller banks (exact $p$-value $=0.017$ ). Consistently, the test shows evidence of some tilt toward larger borrowers early in PPP for both types of banks, but the tilt is more significant for big-10 banks. We obtain the same interpretation when we use a more granular classification of lender types (Appendix B, Figures B.1 and B.2).

We use multinomial logit models to examine the relative odds of larger firms (and loans) being prioritized early more by big-10 banks compared to smaller banks (Table XIV). The specification is fairly straightforward. The dependent variable $Y$ takes the values $0,1,2$, or 3 depending on whether the PPP loan is made by a small bank and late, small bank and early, big bank and late, or big bank and early. The independent variable is the size variable of interest, say the natural logarithm of loan size. We set the second outcome $Y=1$ as the base outcome, that is a small bank making a loan early. The estimates for the size variable in the equation for $Y=3$, that is, a big bank making a loan early, then reflects the propensity of the big bank to make larger loans early relative to the base, which is a small bank making a larger loan early. Table XIV reports the results.

We find that the coefficient of the firm size variable is positive and significant for $Y=3$ (i.e., early borrowers from big-10 banks), indicating that the tilt towards larger loans is greater for big-10 banks than for small banks (Panel A). We also note that the negative and statistically significant coefficient for $Y=2$ (i.e., late borrowers from big-10 banks) is larger in magnitude than the negative coefficient for $Y=0$ (i.e., late borrowers from smaller banks). This comparison suggests even a larger tilt than the coefficient for $Y=3$ alone would suggest. Using the natural logarithm of PPP loan amount rather than the natural logarithm of firm assets produces similar results (Panel B). Additional tests based on the number of firms' employees are reported in Internet Appendix, Figure IA.A.1 and Table IA.A.5. Collectively, the evidence suggests that the lender type matters in whether larger firms get early PPP access.

\section{Bank Relationships}

We now explore whether bank relationships could help mitigate the propensity to prioritize large borrowers early by banks. We match the PPP data to the DealScan bank-firm transaction database (e.g., Schwert (2018)). We use a customized crosswalk to adjust for 
the fact that PPP applications could be through subsidiaries and franchisees rather than the parents. We start with fuzzy matching followed by a case by case manual review of the results for both borrowers and lenders. The match involved 731 current names, approximately 770 former names, and over 7,300 subsidiary names of PPP borrowers in our dataset. We find 593 valid name matches pertaining to 252 public PPP borrowers. This is somewhat sparse relative to the universe of the public PPP borrowers. The ability to match is constrained by what DealScan covers, which is the set of larger firms. Our matched firms are thus larger than unmatched firms.

The tests require us to define bank-borrower relationships. We define a borrower as having a bank relationship if DeasScan records a deal in the 5 years prior to a PPP loan. Only $12.3 \%$ of the 252 PPP borrowers matched with DealScan data had a prior relationship with their PPP lender. Across all matched firms, the mean (median) PPP loan amount for early borrowers is slightly larger at $\$ 4.07$ (\$2.52) million compared to $\$ 3.86(\$ 1.95)$ million for late borrowers. The differences are not significant with a $p$-value of 0.23 . The insignificance extends to the indicators of firm size, with book value of assets and the number of employees that have mean (median) of $\$ 138.6$ (\$59.8) million and 408 (196), respectively, for early borrowers compared to $\$ 154.5$ (\$90.6) million and 452 (284) for late borrowers. The lack of significance reflects the loss of power due to a smaller sample size as the loss of the smaller firms because of the concentration of DealScan matches in larger firms. ${ }^{18}$

The key focus in this section is on bank relationships. For firms with a prior relationship with the PPP lender, the mean (median) PPP loan amount equals $\$ 9.45$ (\$10.00) million for early borrowers versus $\$ 6.44$ (\$6.80) million for late borrowers. The $p$-value for the difference is 0.15 , indicating that the differences are not significant. There is really no evidence that relationships help reverse the prioritization of larger loan amounts early. With the caveat on power due to the DealScan matched-sample limitations, the results are more consistent with intermediary fee incentives shaping who obtains early access to the PPP loans. The results on firm size are similar. The mean (median) firm assets are $\$ 416.0$ (\$397.0) million for early PPP borrowers versus $\$ 466.3$ (\$251.0) million for late borrowers, and the number of COMPUSTAT-disclosed employees is 822 (768) versus 788 (625).

It is informative to compare the patterns of relationship PPP-borrowers with those for PPP applicants who go with non-relationship banks. For these "transactional" PPP borrowers that we do not find going through their relationship banks, the early versus late borrowing amounts have mean (median) of $\$ 3.29$ million ( $\$ 2.20$ million) versus $\$ 3.50$ million (\$1.87 million), respectively, and the differences are not significant economically or statis-

\footnotetext{
${ }^{18}$ The Acharya and Steffen (2020) dataset on the dash for cash, which the authors kindly shared with us, is not useful for our study as it focuses on large firms with assets of at least $\$ 100$ million.
} 
tically. The sharper directional patterns with greater earlier amounts are not visible in this sample. For assets and number of employees, the early-late means (medians) of $\$ 104.9$ (\$53.7) million versus \$115.6 (\$72.0) million and 358 (182) versus 410 (233), respectively, display the same patterns with different directionality in the means and medians. One interpretation of the data is that the new clients applying in a less predictable fashion results in more heterogeneity in the early and late pools. On the other hand, relationship lenders who know their clients and have finite capacity, may have provided "concierge" services in the PPP application process to their most profitable PPP clients when a large number of them apply at essentially the same time. ${ }^{19}$ These patterns are consistent with other incentives (e.g., PPP fees, future business opportunities) also shaping PPP delivery by private lenders after conditioning on bank-borrower relationships. ${ }^{20}$

\section{SBA Private Borrowers Release}

We extend our analysis to the broader sample of all PPP borrowers released by the SBA. The release gives borrower and bank names, data on borrower type (e.g., proprietorship, corporation, LLC, partnership), and the NAICS industry code. The overall SBA sample is large but has limitations. We have no financial data on virtually all the firms, which are private. We also have no share prices, of course, nor do we have exact loan amounts if the loan is larger than $\$ 150,000$. We know only the broad buckets that the loan amounts fall into, which we work with. We are interested in the prioritization of larger borrowers early, which we can analyze using the buckets defining the loan bins rather than the exact amounts. As the data discloses bank names, the tests of bank size pose no new difficulty.

The data show that SBA overall disbursed $\$ 525$ billion in PPP funding to 5.2 million borrowers, about $79.7 \%$ of the PPP appropriation of $\$ 659$ billion. Of this, $\$ 342$ billion (65\%) is disbursed to 1.7 million (33\%) of the borrowers during the initial rush period from April 3, 2020 to April 16, 2020. Thus, the initial PPP disbursements are to larger borrowers. The SBA provides data on recipient types, which could be corporations (28.69\%), limited liability companies (28.07\%), sole proprietorships (15.75\%), Subchapter S corporations (13.64\%), self-employed individuals (4.61\%), and non-profit organizations (3.46\%). The recipients employed 50.92 million workers pre-Covid based on the data in the PPP applications. ${ }^{21}$

\footnotetext{
${ }^{19}$ Media reports provide anecdotal evidence of such "concierge treatment." E.g., see "Banks Gave Richest Clients 'Concierge Treatment' for Pandemic Aid", The New York Times, April 22, 2020 at https://www . nytimes.com/2020/04/22/business/sba-loans-ppp-coronavirus.html.

${ }^{20}$ Further analysis of these patterns is clearly of interest but requires more granular microdata on smallfirm bank relationships especially for the smaller firms and additional data on matching entities that applied at the SBA with their parents or franchisor entities that may be better matched with loan data.

${ }^{21}$ The exact fees are not reported. We estimate that lender fees range from $\$ 14.6$ billion to $\$ 24.9$ billion.
} 
Figure 15 shows the histogram of loan amounts in the early and late stages when the amounts are binned in the categories reported by the SBA. We find that across all banks, larger borrowers are more likely to get early access to PPP funding. The finding echoes what we find for the public firm sample. One issue is that the full SBA sample includes all types of entities applying for loans such as proprietorships or partnerships besides corporations. Certain types of the smallest firms (e.g., non-employers) were allowed to participate in PPP only toward the end of Round 1, which could result in a bias towards finding that small firms come late. We thus identify and focus on the subsample of firms that are incorporated as corporations.

Figure 16 contrasts the densities of early versus late PPP applicants in the SBA data that are corporations, for big-10 banks (Panel A) versus smaller banks (Panel B). We transform loan size bins into a discrete variable where values are the natural logarithm of bins' midpoints. $^{22}$ We see a shift towards smaller firms in the later periods for both types of banks. That is, intermediary effects matter for corporations in the larger SBA sample as well. We also see that the increase in the proportion of the smallest firms in the later period is more pronounced for the big bank sample. Again, the findings are consistent with what we find for the public firm sample: Big banks appear to cater to their largest clients and serve smaller customers later than do small banks. As above, the results are similar when we consider a more granular classification of lender types into four buckets (Appendix B, Figure B.3). As a different proxy for size in the SBA data, we consider the number of jobs supported by the PPP and find consistent results. ${ }^{23}$ Additional tests and robustness checks are reported in Internet Appendix, Figure IA.A.2 and Tables IA.A.3, IA.A.4, IA.B.7, and IA.B.8.

We turn to a multinomial logit model in Table XV to examine the relative odds of larger PPP loans being prioritized early more by big-10 banks compared to smaller banks. now for the overall sample of corporations in the SBA PPP data. Similarly to the tests based on our public PPP borrower sample, we set the dependent variable $Y$ equal to 0, 1, 2, or 3 depending on whether the PPP loan is made by a small bank and late, small bank and early, big bank and late, or big bank and early ( $Y=1$ is the base outcome). The independent variables are loan size bin dummies, where the smallest loan size category (PPP loans $<\$ 150 \mathrm{k}$ ) is omitted. Consistently with the results on public PPP recipients, we find that big-10 banks tilt their distributions of PPP clients toward larger PPP loans early in the PPP more than smaller banks do. The results are robust to excluding lenders with few PPP loans (Internet Appendix, Table IA.B.9). Additional results based on the number of jobs supported by PPP

\footnotetext{
${ }^{22}$ We do this transformation for the ease of exposition and for comparability with results on public firms.

${ }^{23}$ The number of firm's jobs reported in the SBA data may be lower than the number of firm's employees because firms may exclude certain employees from the PPP application due to PPP requirements (e.g., foreign employees) or because not all firm's affiliates are able to apply.
} 
are reported in Internet Appendix, Tables IA.A.6 and IA.B.10.

In sum, the section shows two results consistent with lender effects in how subsidized government funding flows to the targeted small businesses. First, the larger among the small firms are more likely to be funded in the early stages of the PPP. This result is less consistent with the hypothesis that firms with more immediate credit demands get funds first. It more likely reflects the role of bank intermediaries in putting the larger companies first. Second, the large versus small preference appears to be more pronounced for the big banks in our sample. The latter finding is consistent with the idea that small firms benefit from relationships with small banks but the rationale is novel as it obtains in a setting where differences in soft information and its processing are not relevant. Particularly in stressed times when banks must prioritize resources, smaller firms are less likely to be set back in the queue with a small bank. The benefits of small firms being with small banks may thus have a broader rationale than the traditional explanation where the main advantage of small firms being with small banks is the processing of soft information. Exploring this further in different settings is a profitable area for future research.

\section{Conclusion}

The Paycheck Protection Program (PPP), a fiscal stimulus program in the U.S., aims to help small businesses suffering from the economic fallout of the Covid-19 pandemic. At $\$ 669$ billion in fiscal commitments, the PPP is a significant portion of the $\$ 2$ trillion CARES Act package intended to help the country through the deep, sudden, and widespread economic contraction and job losses from the Covid-19 pandemic.

We study the PPP for small public firms. Our sample firms are in the lowest decile of market capitalization and are highly constrained even in normal times. The PPP is a very positive shock in the supply of financing for these firms. The funds are available immediately and at very attractive terms such as a concessional $1 \%$ interest rate and principal forgiveness.

We find that firms that take PPP funds experience positive valuation effects. The treatment effects indicate a positive bang for the buck on average especially for the larger and stronger firms. The treatment effect estimates represent progress on estimating the treatment effects of the PPP. An important empirical issue in this estimation is the confounding impact of the other elements of the $\$ 2$ trillion CARES Act package announced along with PPP. The staggering of the treatment dates in our experiment design mitigates some of these concerns. The valuation effects we estimate accrue when markets learn about PPP applications, which are disjoint from the program announcement dates and spread across firms. We can thus isolate the PPP-related effects more precisely. We make econometric 
adjustments of treatment effects for the fact that financial markets may partially anticipate and thus impound some of the effects ahead of the actual application dates.

Despite the attractiveness of the PPP funding, the small firms in our sample exhibit reluctance to take PPP funds. As the program unfolds, a sizable fraction of the firms who obtained program funds return the funds without using them. Interestingly, returning PPP funds results in positive announcement effects although giving up subsidized finance should decrease shareholder value. The findings suggest that although the direct costs of PPP funds are low, taking PPP funds imposes significant indirect costs on participants. The costs appear to be related to the possibility of ex-post investigations of PPP recipients. Of concern are the subjectivity in the audit process, the broad powers of the government to seek remedies, and especially an openly adversarial stance towards public firms articulated in its pronouncements. It does not seem surprising that firms choose to turn away from PPP funding. Firms stronger before the pandemic tend to do so, concentrating PPP funds among the financially weaker applicants.

From a policy viewpoint, our findings suggest that when taxpayer funding is involved, policymakers should focus on both objective standards for program eligibility and also specify with similar objectivity the conduct of the ex-post audits concerning funds use. For instance, delineating safe harbors to circumscribe litigation, a standard practice in securities law since the 1930s, may be an appropriate tool in designing government aid programs.

The second portion of our analysis notes that the PPP is also a shock in loan demand for banks making the PPP loans. The initial rush for PPP funding and the excess of the demand over the initial aggregate PPP allocation of $\$ 349$ billion forced banks to prioritize clients seeking the PPP funds. Observing their allocation patterns thus sheds light on how the intermediary supply effects impact the flow and distribution of the government funding.

From the viewpoint of loan demand, the smaller, more constrained and vulnerable firms need funding and thus should access PPP funding sooner. On the other hand, if the priorities of the intermediaries supplying PPP loans matter, the larger clients should gain access to PPP funds sooner as these firms offer greater revenues from the PPP transaction and in the future. Which of these effects dominate? We find robust support for the intermediary supply viewpoint: Large clients are more likely to obtain early PPP access. Using the available DealScan data on bank relationships, we find no evidence that relationships help undo the prioritization of larger clients. Moreover, the pattern of preference for larger clients is seen both in the listed firm sample and in the larger SBA sample of all corporations borrowing in the PPP program.

We also find that the pattern prioritizing large clients early in the PPP process is more pronounced in big banks. Thus, in big banks, small firms face negative externalities from 
the larger clients, a "small fish in a big pond" effect. The evidence suggests that besides the more intensive usage of soft information in small banks, there is another rationale for pairing small firms with small banks. When capacity constraints arise - as in the PPP but also in other shocks that can arise from time to time - small businesses face negative externalities when the larger clients are prioritized more. This effect matters less when small business lending is a mainstay of business as is the case for small banks. More generally, where small firms should domicile their bank relationships appears to be worthy of further research.

To summarize, the PPP, a large U.S. government stimulus program to aid small firms, has the hallmarks of a well designed program including transparent eligibility criteria and very attractive terms. While these features should make the program broadly accessible, we find that its delivery is shaped by the concerns and incentives of its key participants.

On the demand side, concerns about the subjectivity, the scope, and potential disruptions of ex-post government investigations appear to be a significant deterrent to uptake. Thus, it seems important to not only set objective standards for who can get PPP funding but also similarly objective and credible standards for actions after uptake including the audit process, adverse determinations, and any outcomes. On the the supply side, the incentives of the intermediaries charged to deliver funding matter. Understanding these demand and supply forces can help design better policies and also shed light on research issues such as the costs of being public and the nature of firm-bank relationships, especially for small firms. 


\section{REFERENCES}

Acharya, Sankarshan, 1988, A generalized econometric model and tests of a signalling hypothesis with two discrete signals, Journal of Finance 43, 413-429.

Acharya, Viral V., Robert Engle, and Sascha Steffen, 2020, What explains the crash of bank stock prices during COVID-19? The role of health, financial and oil price risks, Working paper, New York University and Frankfurt School of Finance and Management.

Acharya, Viral V, and Sascha Steffen, 2020, The risk of being a fallen angel and the corporate dash for cash in the midst of COVID, CEPR COVID Economics 10.

Alexander, Cindy R, 1999, On the nature of the reputational penalty for corporate crime: Evidence, Journal of Law and Economics 42, 489-526.

Altman, Edward I, 1968, Financial ratios, discriminant analysis and the prediction of corporate bankruptcy, Journal of Finance 23, 589-609.

Armour, John, Colin Mayer, and Andrea Polo, 2017, Regulatory sanctions and reputational damage in financial markets, Journal of Financial and Quantitative Analysis 52, 14291448.

Baker, Scott R, Nicholas Bloom, Steven J Davis, Kyle J Kost, Marco C Sammon, and Tasaneeya Viratyosin, 2020, The unprecedented stock market impact of COVID-19, Working paper, NBER, Northwestern University, Stanford University, University of Chicago, and University of Pennsylvania.

Banerjee, Abhijit V, and Esther Duflo, 2014, Do firms want to borrow more? Testing credit constraints using a directed lending program, Review of Economic Studies 81, 572-607.

Bartik, Alexander W, Zoe B Cullen, Edward L Glaeser, Michael Luca, Christopher T Stanton, and Adi Sunderam, 2020, The targeting and impact of Paycheck Protection Program loans to small businesses, Working paper, NBER, University of Illinois at UrbanaChampaign and Harvard University.

Bartlett, Robert P, and Adair Morse, 2020, Small business survival capabilities and policy effectiveness: Evidence from Oakland, Working paper, NBER, University of California, Berkeley.

Berger, Allen N, Nathan H Miller, Mitchell A Petersen, Raghuram G Rajan, and Jeremy C

Stein, 2005, Does function follow organizational form? Evidence from the lending practices of large and small banks, Journal of Financial Economics 76, 237-269.

Berger, Allen N, and Gregory F Udell, 1995, Relationship lending and lines of credit in small firm finance, Journal of Business 351-381. 
Berk, Jonathan B, Richard Stanton, and Josef Zechner, 2010, Human capital, bankruptcy, and capital structure, Journal of Finance 65, 891-926.

Bharath, Sreedhar, Sandeep Dahiya, Anthony Saunders, and Anand Srinivasan, 2007, So what do I get? The bank's view of lending relationships, Journal of Financial Economics 85, 368-419.

Bharath, Sreedhar T, and Tyler Shumway, 2008, Forecasting default with the Merton distance to default model, Review of Financial Studies 21, 1339-1369.

Billett, Matthew T, Mark J Flannery, and Jon A Garfinkel, 1995, The effect of lender identity on a borrowing firm's equity return, Journal of Finance 50, 699-718.

Chen, Shuyue, Steven Wei Ho, and Clark Liu, 2019, Bank loan announcement effects Evidence from a comprehensive 8-K sample, Working paper, Tsinghua University and Columbia University.

Chen, Yunsen, Song Zhu, and Yutao Wang, 2011, Corporate fraud and bank loans: Evidence from China, China Journal of Accounting Research 4, 155-165.

Chetty, Raj, John N Friedman, Nathaniel Hendren, Michael Stepner, et al., 2020, How did Covid-19 and stabilization policies affect spending and employment? A new real-time economic tracker based on private sector data, Working paper, NBER, Harvard University and Brown University.

Cororaton, Anna, and Samuel Rosen, 2020, Public firm borrowers of the US Paycheck Protection Program, Working paper, Southern Methodist University and Temple University.

De Vito, Antonio, and Juan-Pedro Gomez, 2020, Estimating the COVID-19 cash crunch: Global evidence and policy, Journal of Accounting and Public Policy 106741.

Ding, Wenzhi, Ross Levine, Chen Lin, and Wensi Xie, 2020, Corporate immunity to the COVID-19 pandemic, Working paper, NBER, University of Hong Kong, University of California at Berkeley, and Chinese University of Hong Kong.

Drucker, Steven, and Manju Puri, 2005, On the benefits of concurrent lending and underwriting, Journal of Finance 60, 2763-2799.

Duan, Jin-Chuan, Tao Wang, et al., 2012, Measuring distance-to-default for financial and non-financial firms, World Scientific Book Chapters 95-108.

Eckbo, B Espen, Vojislav Maksimovic, and Joseph Williams, 1990, Consistent estimation of cross-sectional models in event studies, Review of Financial Studies 3, 343-365.

Erel, Isil, and Jack Liebersohn, 2020, Does FinTech substitute for banks? Evidence from the Paycheck Protection Program, Working paper, NBER, Ohio State University and University of California Irvine. 
Fahlenbrach, Rüdiger, Kevin Rageth, and René M Stulz, 2020, How valuable is financial flexibility when revenue stops? Evidence from the Covid-19 crisis, Working paper, NBER, Swiss Finance Institute at EPFL and Ohio State University.

Faulkender, Michael, and Mitchell A Petersen, 2006, Does the source of capital affect capital structure?, Review of Financial Studies 19, 45-79.

Fich, Eliezer M, and Anil Shivdasani, 2007, Financial fraud, director reputation, and shareholder wealth, Journal of Financial Economics 86, 306-336.

Granja, João, Christos Makridis, Constantine Yannelis, and Eric Zwick, 2020, Did the Paycheck Protection Program hit the target?, Working paper, NBER, University of Chicago and Massachusetts Institute of Technology.

Hadlock, Charles J, and Joshua R Pierce, 2010, New evidence on measuring financial constraints: Moving beyond the KZ index, Review of Financial Studies 23, 1909-1940.

Hanson, Samuel, Jeremy Stein, Adi Sunderam, and Eric Zwick, 2020, Business continuity insurance and business continuity loans: Keeping America's lights on during the pandemic, Working paper, Harvard University and University of Chicago.

Haslem, Bruce, Irena Hutton, and Aimee Hoffmann Smith, 2017, How much do corporate defendants really lose? A new verdict on the reputation loss induced by corporate litigation, Financial Management 46, 323-358.

Hassan, Tarek Alexander, Stephan Hollander, Laurence van Lent, and Ahmed Tahoun, 2020, Firm-level exposure to epidemic diseases: Covid-19, SARS, and H1N1, Working paper, NBER, Boston University, Tillburg University, Frankfurt School of Finance and Management, and London Business School.

Heitz, Amanda, Ganapathi S Narayanamoorthy, and Morad Zekhnini, 2020, The disappearing earnings announcement premium, Working paper, Tulane University.

Hoberg, Gerard, and Vojislav Maksimovic, 2015, Redefining financial constraints: A textbased analysis, Review of Financial Studies 28, 1312-1352.

James, Christopher, 1987, Some evidence on the uniqueness of bank loans, Journal of Financial Economics 19, 217-235.

Jarrell, Gregg, and Sam Peltzman, 1985, The impact of product recalls on the wealth of sellers, Journal of Political Economy 93, 512-536.

Kaplan, Steven N, and Luigi Zingales, 1997, Do investment-cash flow sensitivities provide useful measures of financing constraints?, Quarterly Journal of Economics 112, 169-215.

Karpoff, Jonathan M, D Scott Lee, and Gerald S Martin, 2008, The cost to firms of cooking the books, Journal of Financial and Quantitative Analysis 43, 581-611. 
Khwaja, Asim Ijaz, and Atif Mian, 2008, Tracing the impact of bank liquidity shocks: Evidence from an emerging market, American Economic Review 98, 1413-42.

Kim, Dasol, 2020, Economic externalities of bank liquidity, Working paper, Office of Financial Research.

Korteweg, Arthur, 2010, The net benefits to leverage, Journal of Finance 65, 2137-2170.

Lin, Huidan, and Daniel Paravisini, 2011, What's bank reputation worth? The effect of fraud on financial contracts and investment, Working pape, IMF and LSE.

Loughran, Tim, and Bill McDonald, 2020, Management disclosure of risk factors and COVID-19, Working paper, University of Notre Dame.

Lummer, Scott L, and John J McConnell, 1989, Further evidence on the bank lending process and the capital-market response to bank loan agreements, Journal of Financial Economics $25,99-122$.

Murphy, Deborah L, Ronald E Shrieves, and Samuel L Tibbs, 2009, Understanding the penalties associated with corporate misconduct: An empirical examination of earnings and risk, Journal of Financial and Quantitative Analysis 55-83.

Petersen, Mitchell A, and Raghuram G Rajan, 1994, The benefits of lending relationships: Evidence from small business data, Journal of Finance 49, 3-37.

Prabhala, Nagpurnanand R, 1997, Conditional methods in event studies and an equilibrium justification for standard event-study procedures, Review of Financial Studies 10, 1-38.

Ramelli, Stefano, and Alexander F Wagner, 2020, Feverish stock price reactions to Covid-19, Working paper, CEPR, University of Zurich.

Schwert, Michael, 2018, Bank capital and lending relationships, Journal of Finance 73, 787830.

Seguin, Paul J, and Margaret Monroe Smoller, 1997, Share price and mortality: An empirical evaluation of newly listed Nasdaq stocks, Journal of Financial Economics 45, 333-363.

Slutzky, Pablo, 2020, The hidden costs of being public: Evidence from multinational firms operating in an emerging market, Journal of Financial Economics forthcoming.

Stein, Jeremy C, 2002, Information production and capital allocation: Decentralized versus hierarchical firms, Journal of Finance 57, 1891-1921.

Strebulaev, Ilya A, and Baozhong Yang, 2013, The mystery of zero-leverage firms, Journal of Financial Economics 109, 1-23.

Whited, Toni M, and Guojun Wu, 2006, Financial constraints risk, Review of Financial Studies 19, 531-559. 


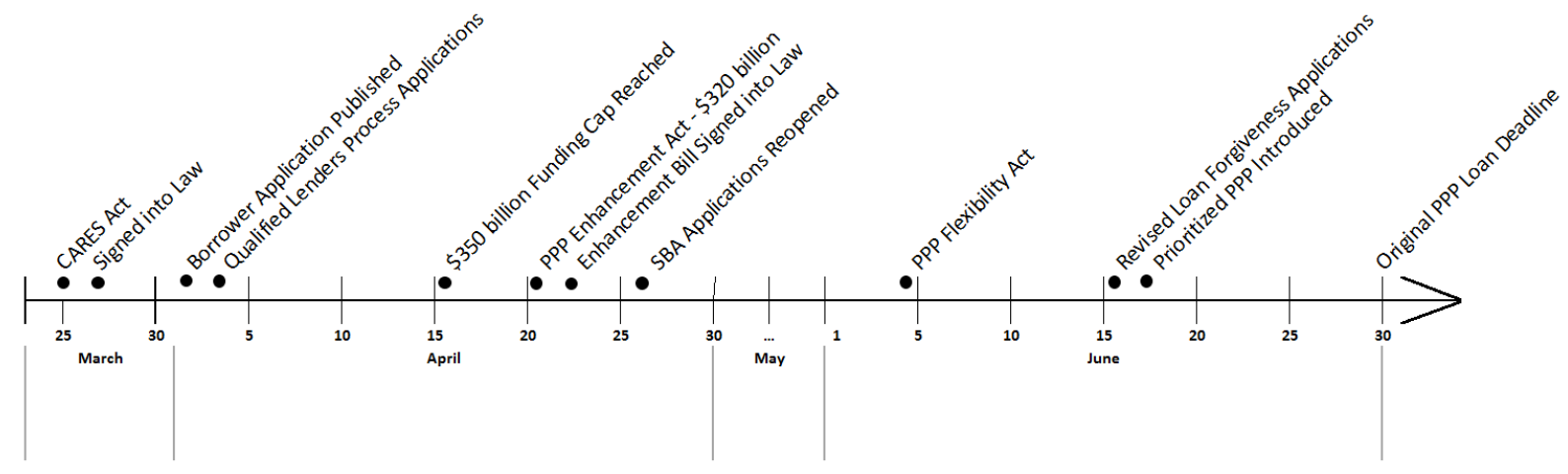

Figure 1. PPP timeline. This figure illustrates the timeline and key milestones of the Paycheck Protection Program (PPP).
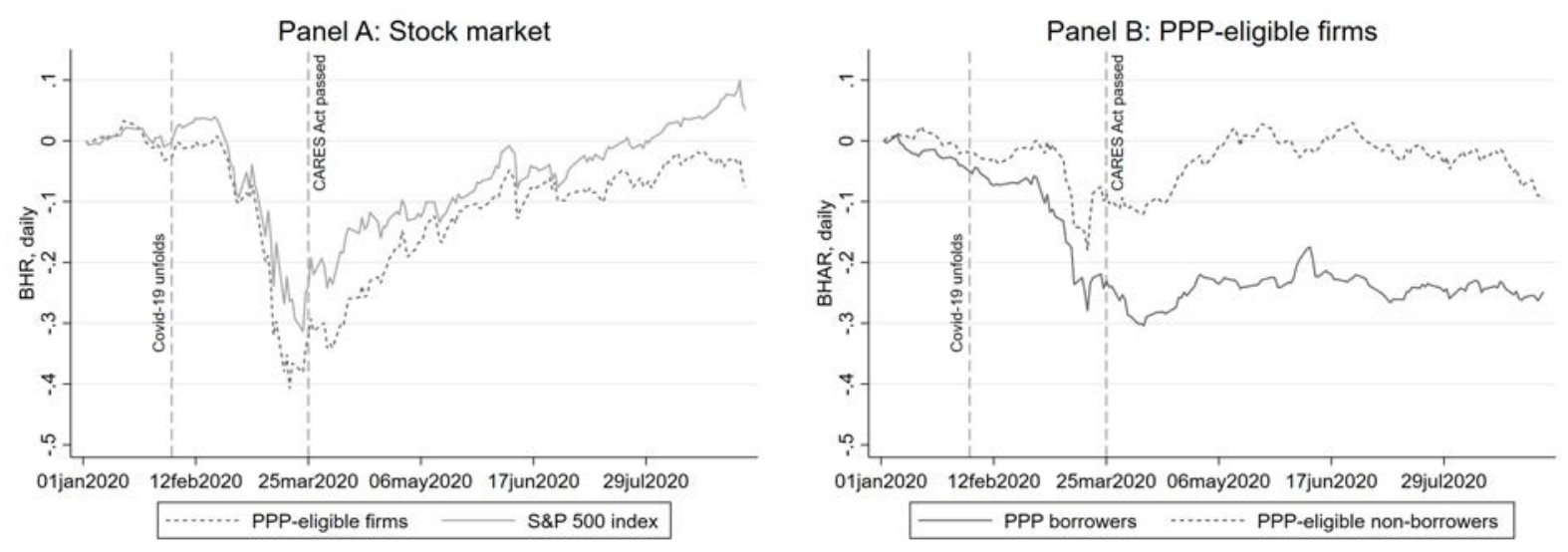

Figure 2. Evolution of PPP borrower returns: PPP applicants and control firms. This figure plots daily buy-and-hold average returns (BHRs) for PPP-eligible small public firms versus the S\&P 500 index (Panel A) and buy-and-hold average abnormal returns (BHARs) for PPP borrowers versus PPP-eligible non-borrowers (Panel B), from January to August 2020. We define the abnormal return as the stock return over the S\&P 500 return. We exclude penny stocks, which we define as stocks with an average share price of less than $\$ 5$ in December 2019, because of illiquidity. BHAR is set to zero for the first trading day of the year, which is January 2, 2020. 


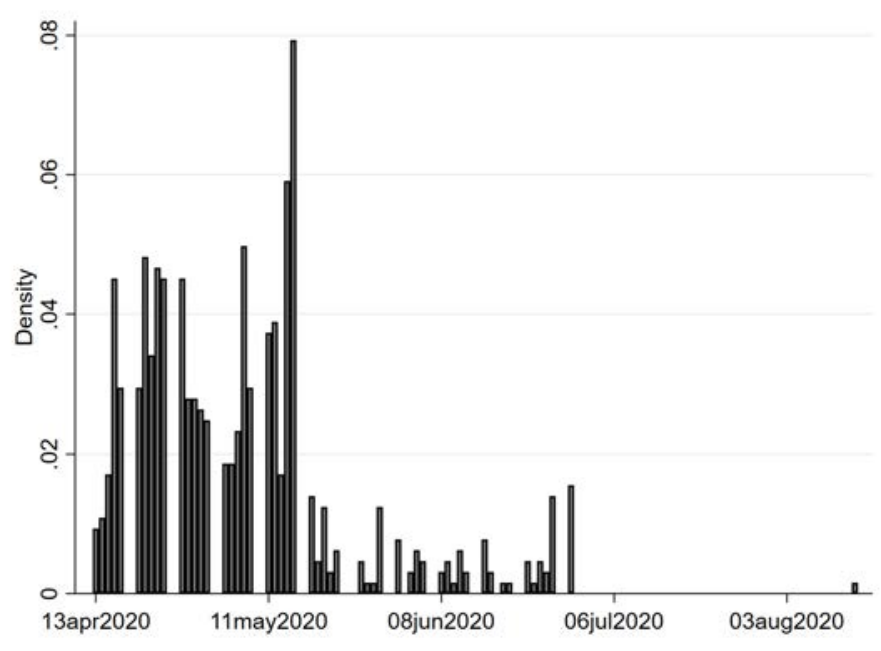

Figure 3. Density of PPP loan grant announcement dates. This figure plots the density of announcement dates for PPP loan grant announcements.

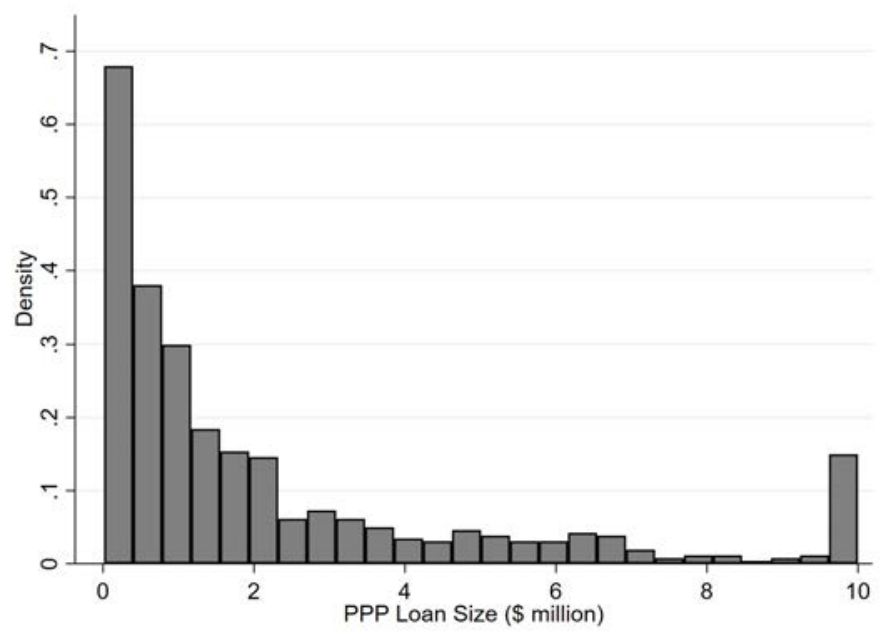

Figure 4. PPP loan size distribution. This figure plots the density of PPP loan size for all PPP applicants. We set PPP loan size equal to $\$ 10 \mathrm{M}$ for loans above $\$ 10 \mathrm{M}$, for the ease of exposition. 

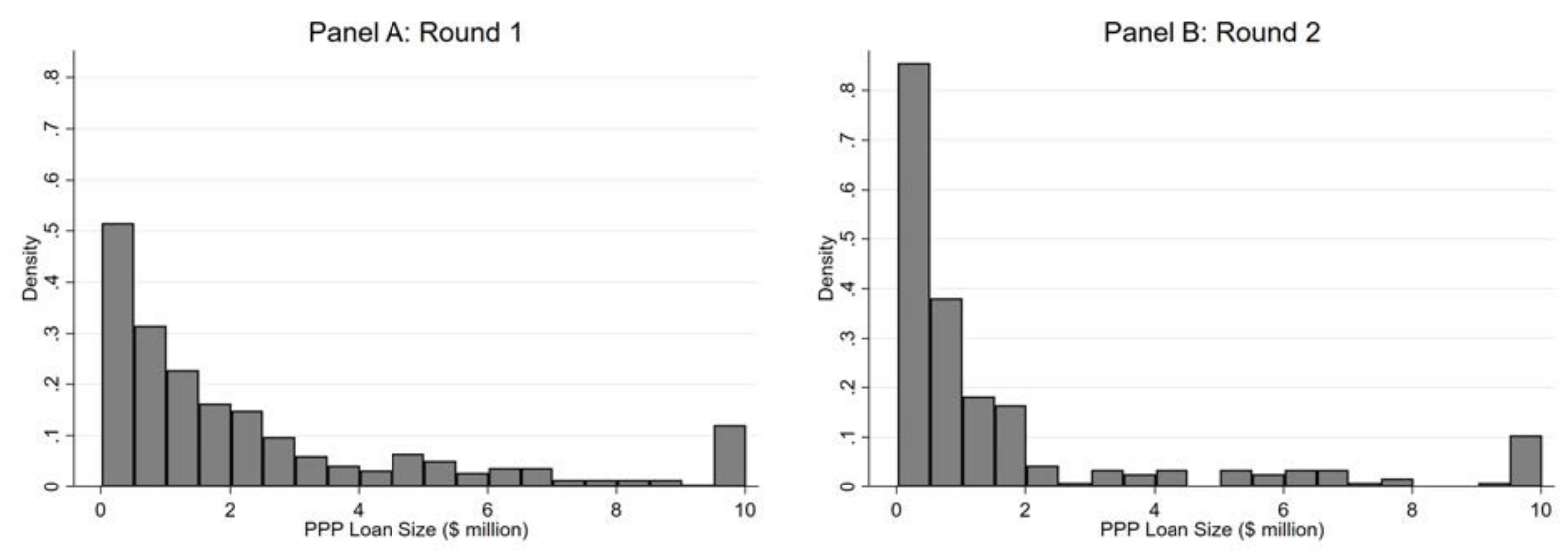

Figure 5. PPP loan size by PPP Round. This figure plots the density of PPP loan size for PPP Round 1 (before April 17, 2020) versus PPP Round 2 (after April 26, 2020). We set PPP loan size equal to $\$ 10 \mathrm{M}$ for loans above $\$ 10 \mathrm{M}$, for the ease of exposition.
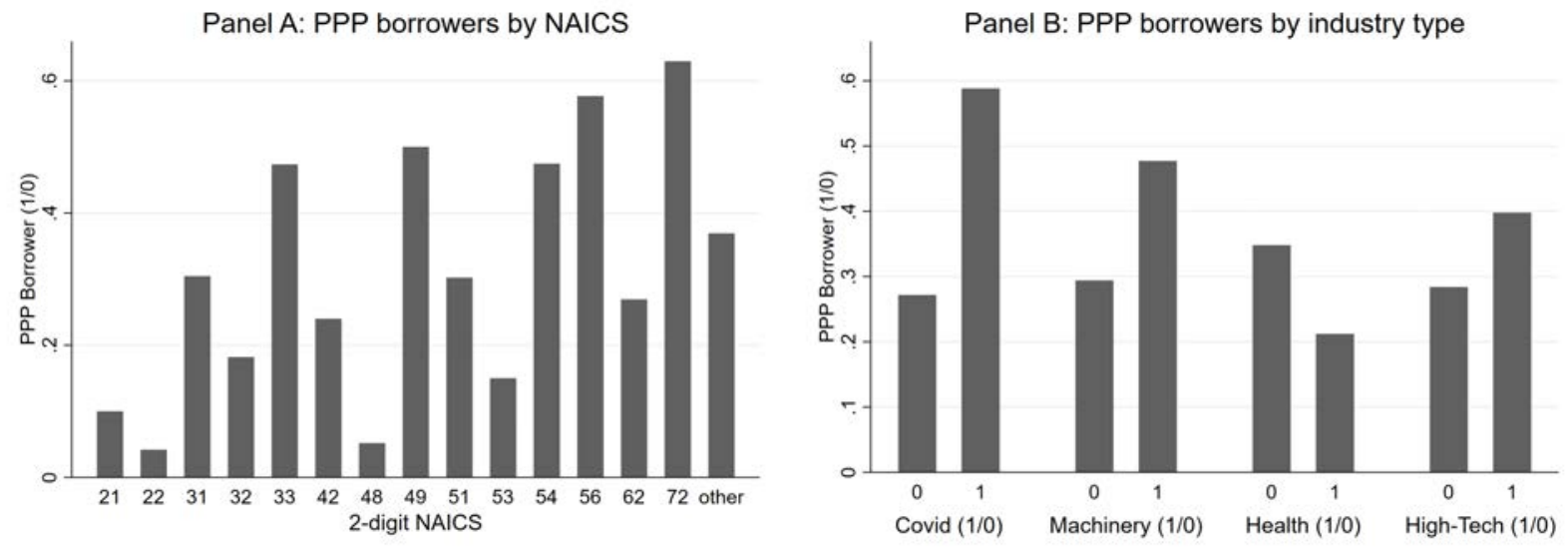

Figure 6. Public PPP borrowers by industry. This figure plots the share of PPP-eligible U.S. public companies that were granted a PPP loan, by NAICS (Panel A) and industry type (Panel B). We measure industry using 2-digit NAICS as follows: 21 = Mining, Quarrying, and Oil and Gas Extraction; $22=$ Utilities; 31-33= Manufacturing; $42=$ Wholesale Trade; $48=$ Transportation and Warehousing; 51 = Information; 53 = Real Estate and Rental and Leasing; $54=$ Professional, Scientific, and Technical Services; $56=$ Administrative and Support and Waste Management and Remediation Services; $62=$ Health Care and Social Assistance; $71=$ Arts, Entertainment, and Recreation; $72=$ Accommodation and Food Services; and other = Other (except Public Administration). 

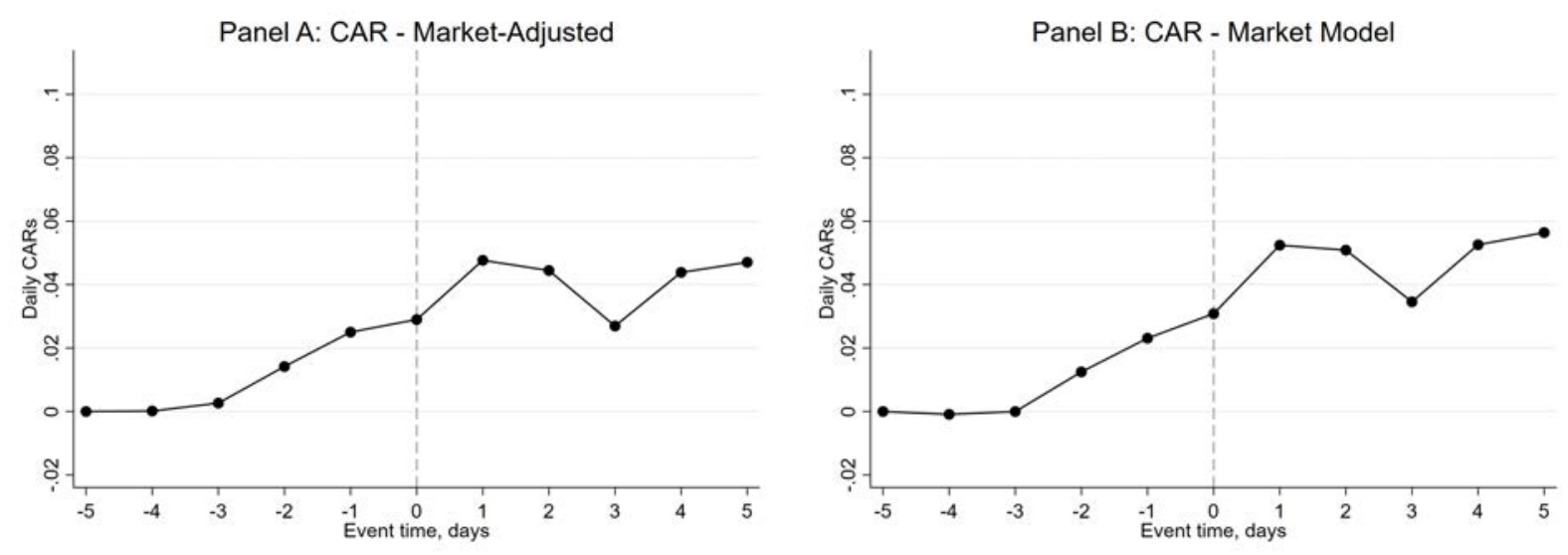

Figure 7. Cumulative abnormal returns (CARs) around PPP loan grant announcement dates. This figure plots daily CARs for PPP loan grant announcements. The abnormal return in Panel A is the stock return minus the $\mathrm{S} \& \mathrm{P} 500$ return, where the abnormal return is set to zero for Day -5. The abnormal return in Panel B is calculated using the market model based on S\&P 500 return, where the abnormal return is set to zero for Day -5 . The dots are the daily CARs and vertical error bars are the $90 \%$ confidence intervals. We exclude penny stocks, which we define as stocks with an average share price of less than $\$ 5$ in December 2019.

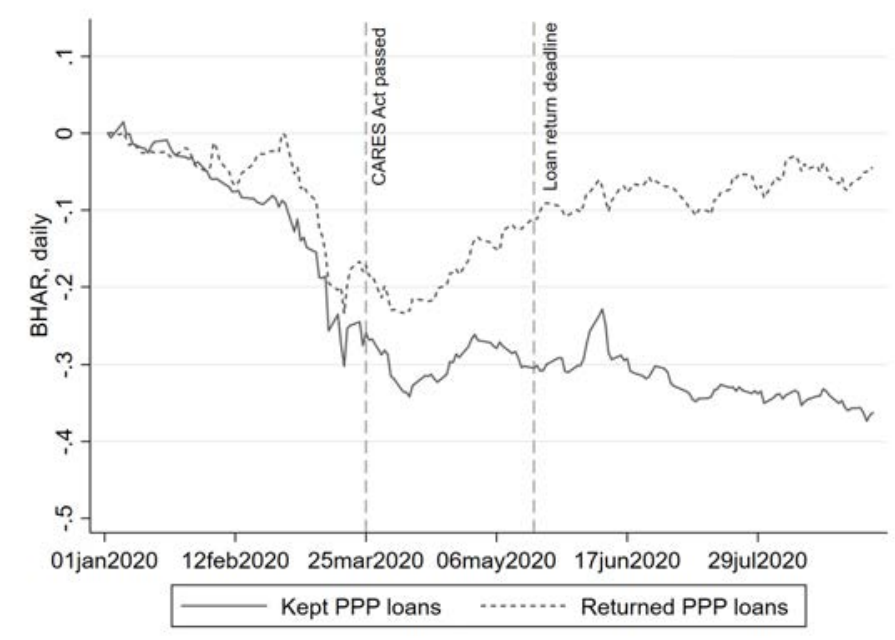

Figure 8. Evolution of PPP borrower returns: PPP returners and retainers. This figure plots daily buy-and-hold average abnormal returns (BHARs) for PPP returners versus retainers from January to August 2020, where the abnormal return is the stock return over the S\&P 500 return. We exclude penny stocks, which we define as stocks with an average share price of less than $\$ 5$ in December 2019, because of illiquidity. BHAR is set to zero for the first trading day of the year, which is January 2, 2020. 

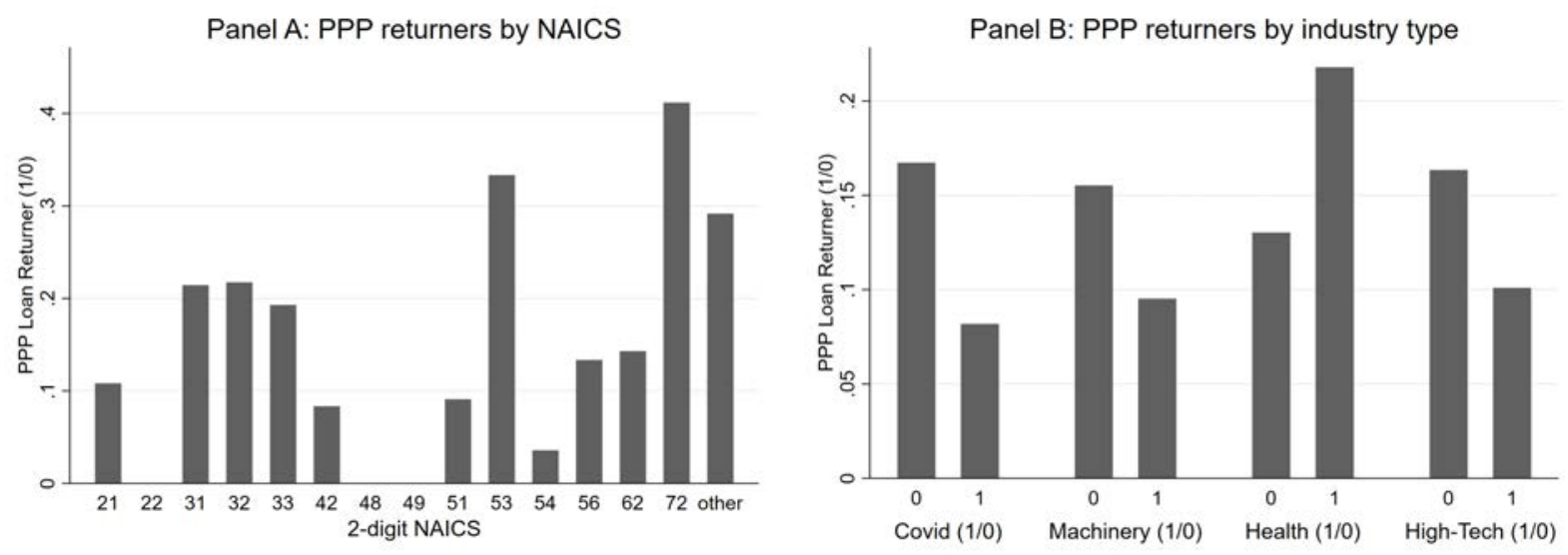

Figure 9. Firms that return PPP loans by industry. This figure plots the share of PPP borrowers that returned the PPP loans to the SBA, by NAICS (Panel A) and industry type (Panel B). See Fig. 6 for NAICS definitions.

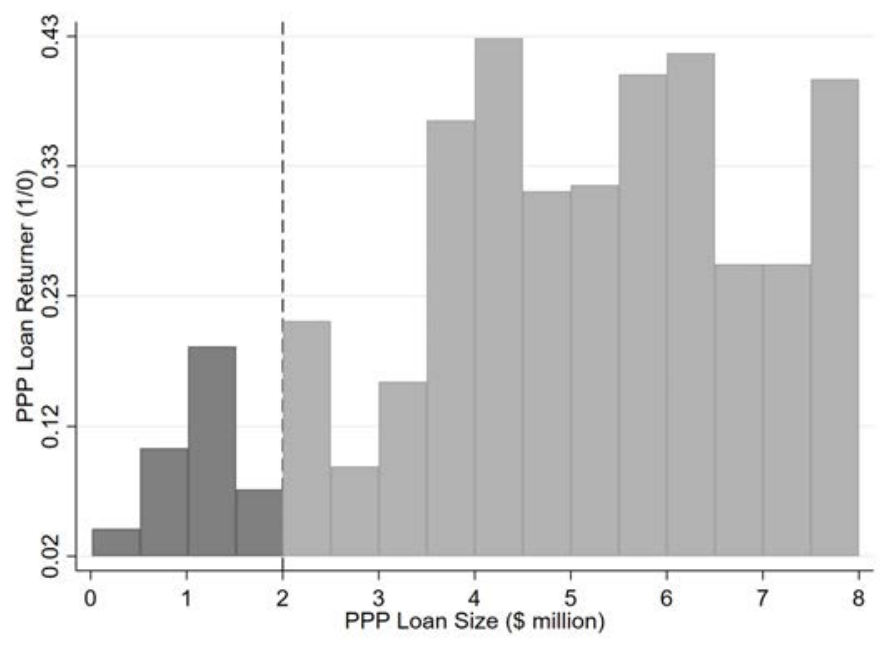

Figure 10. PPP loan repayment probability by loan size. This figure plots the probability of U.S. public borrowers returning PPP loans to the SBA, by PPP loan size bin. The vertical line is the loan amount of $\$ 2$ million. We set PPP loan size equal to $\$ 8 \mathrm{M}$ for loans above $\$ 8 \mathrm{M}$, for the ease of exposition. 


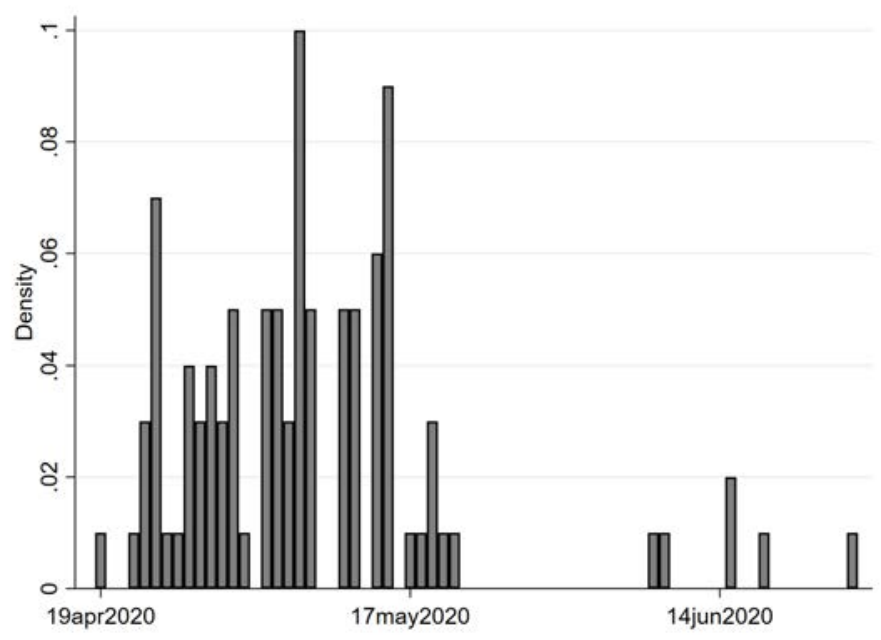

Figure 11. Density of PPP loan return announcement dates. This figure plots the density of announcement dates for PPP loan repayment announcements. We omit two announcement dates in August 2020, for the ease of exposition.
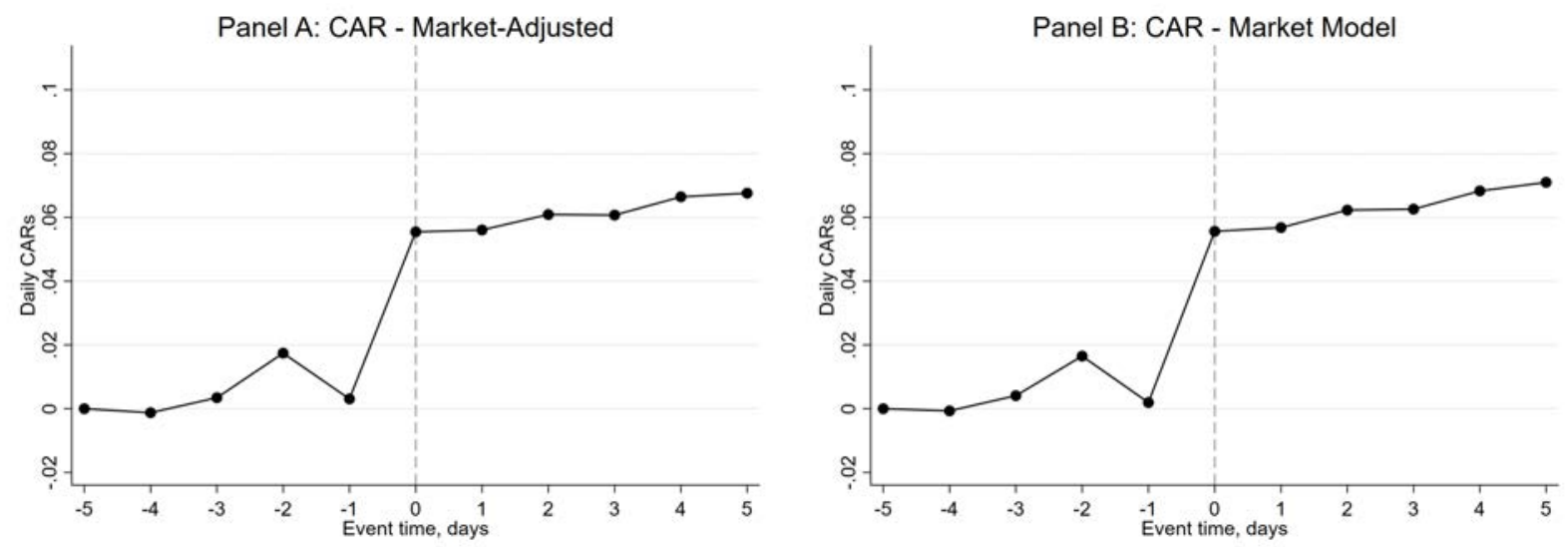

Figure 12. Cumulative abnormal returns (CARs) around PPP loan return announcement dates. This figure plots daily CARs for PPP loan return announcements. The abnormal return in Panel A is the stock return minus the $\mathrm{S} \& \mathrm{P} 500$ return, where the abnormal return is set to zero for Day -5. The abnormal return in Panel B is calculated using the market model based on S\&P 500 return, where the abnormal return is set to zero for Day -5 . The dots are the daily CARs and vertical error bars are the $90 \%$ confidence intervals. We exclude penny stocks, which we define as stocks with an average share price of less than $\$ 5$ in December 2019. 

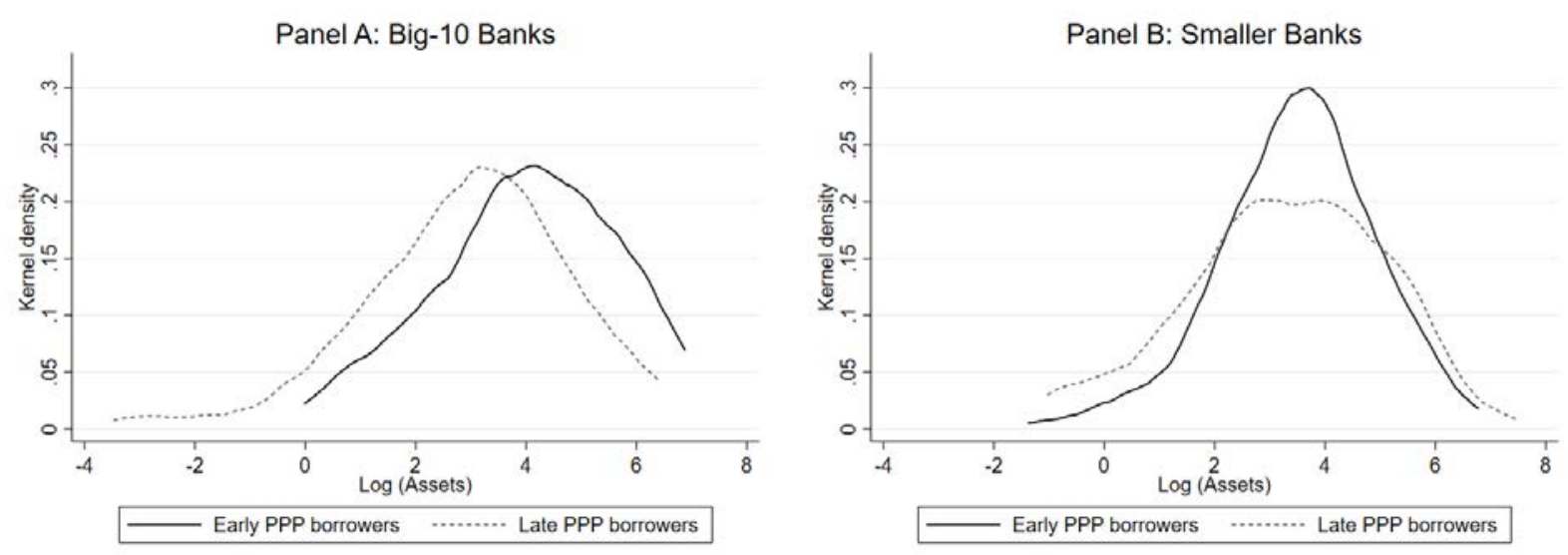

Figure 13. Early PPP borrowing and firm assets by big-10 versus smaller banks. This figure plots kernel densities of the natural logarithm of firm's assets for early versus late public PPP borrowers. Panel A reports the results for big-10 banks. Panel B reports the results for smaller (non-big-10) banks. Log (Assets) is winsorized at the $1^{\text {st }}$ and the $99^{\text {th }}$ percentiles.
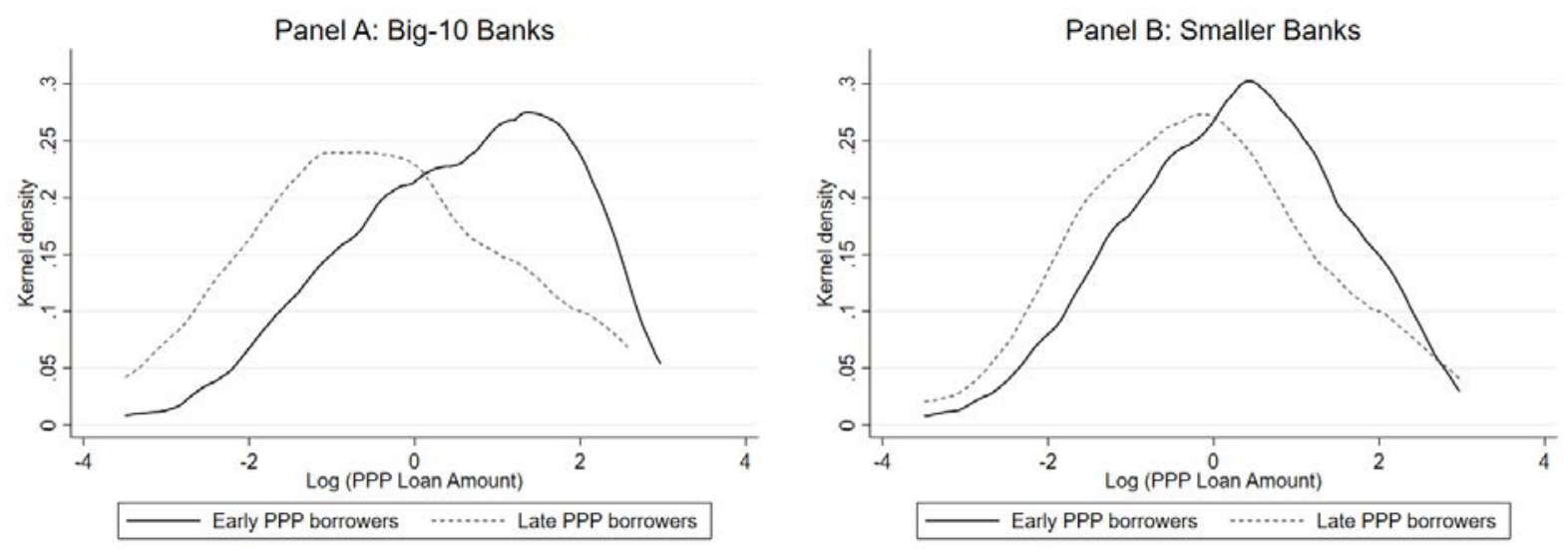

Figure 14. Early PPP borrowing and PPP loan size by big-10 versus smaller banks. This figure plots kernel densities of the natural logarithm of PPP loan amount for early versus late public PPP borrowers. Panel A reports the results for big-10 banks. Panel B reports the results for smaller (non-big-10) banks. Log (PPP Loan Amount) is winsorized at the $1^{\text {st }}$ and the $99^{\text {th }}$ percentiles. 

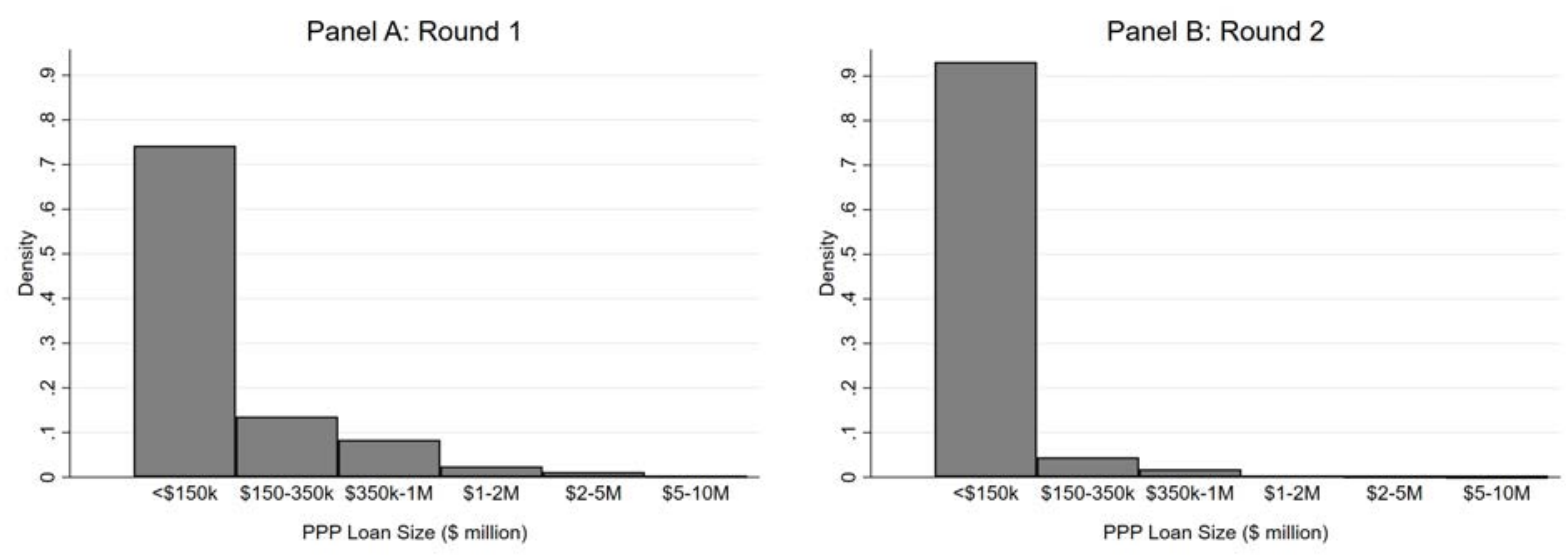

Figure 15. PPP loan size by PPP Round: SBA PPP data. This figure plots the density of PPP loan size for PPP Round 1 (before April 17, 2020) versus PPP Round 2 (after April 26, 2020). The sample is based on SBA PPP data and includes all PPP borrowers.
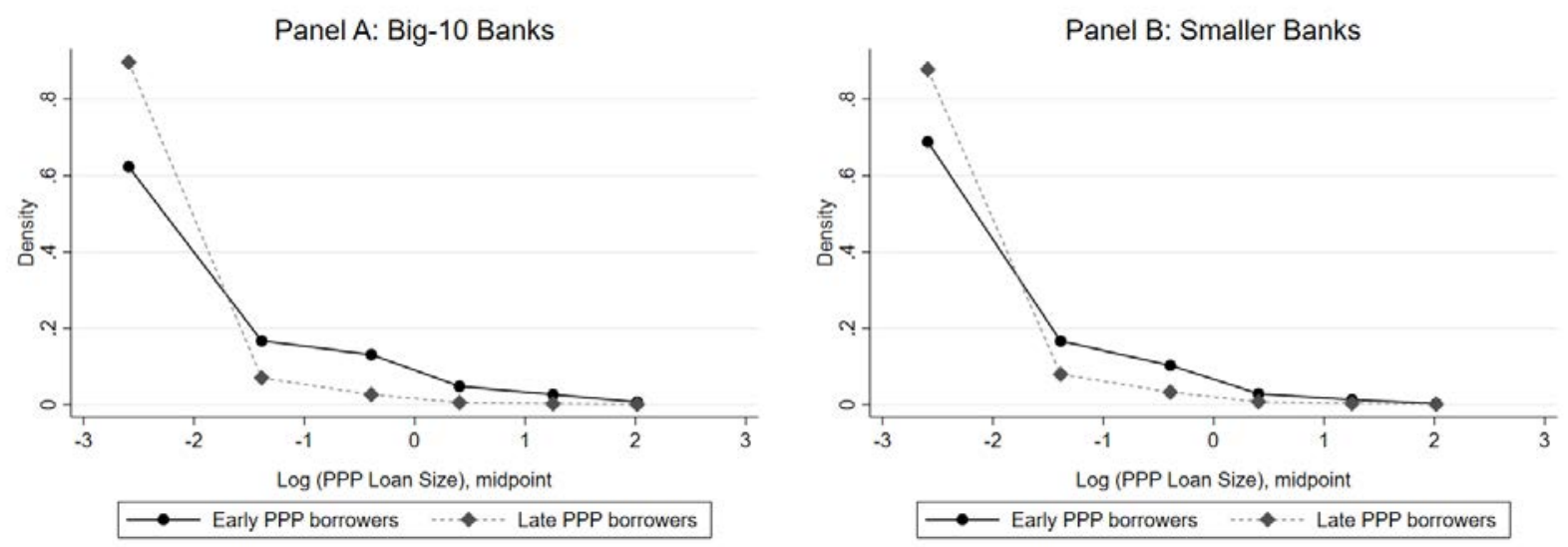

Figure 16. Early PPP borrowing by big-10 versus smaller banks: SBA PPP data. This figure plots densities of a discrete PPP loan size variable which values are the natural logarithm of midpoints of PPP loan size bins (as binned by SBA). The sample is based on SBA PPP data, which we restrict to corporations, for comparability. Panel A reports the results for big-10 banks. Panel B reports the results for smaller (non-big-10) banks, with this category including non-bank lenders. Excluding non-bank lenders or including other types of business does not affect the results. 


\section{Table I}

\section{PPP borrower sample}

Column (1) report the number of observations at each stage of PPP borrower sample construction. Column (2) reports the respective numbers for firms that subsequently returned PPP loans to SBA.

\begin{tabular}{lcc}
\hline & All PPP Borrowers & PPP Loan Returners \\
\cline { 2 - 3 } & $(1)$ & $(2)$ \\
\hline 1. Initial PPP borrower sample & 731 & 111 \\
2. Exclusions based on economic considerations: & 53 & 7 \\
Reason 1: Financial firm & 53 & 7 \\
Reason 2: Special purpose acquisition company (SPAC) & 0 & 0 \\
3. Final sample, including: & 678 & 104 \\
Matched to Compustat & 553 & 100 \\
Matched to Yahoo! Finance & 644 & 104 \\
Matched to SBA's July PPP disclosure & 541 & 13 \\
Matched to Lender RSSD IDs (e.g., FDIC, FFIEC, NCUA) & 620 & 84 \\
Matched to DealScan & 252 & 47 \\
4. PPP announcements, including: & 678 & 104 \\
PPP announcements from 8-K filings & 438 & 67 \\
PPP announcements from 10-Qs, 10-Ks, and other sources & 240 & 37 \\
\hline
\end{tabular}




\section{Table II}

\section{Summary statistics: Publicly listed PPP applicants and control firms}

Columns (1) to (3) report the mean, median, and standard deviation of several financial characteristics of firms that applied for PPP loans. Columns (4) to (6) report the same statistics for PPP-eligible COMPUSTAT firms that did not apply. Column (7) reports the number of observations and Column (8) reports p-values from a Wilcoxon rank sum test comparing applicants with non-applicants. In the case of discrete variables, the statistics are proportions and the p-values are for tests of the difference in proportions. Continuous variables are winsorized at the $1^{\text {st }}$ and the $99^{\text {th }}$ percentiles.

\begin{tabular}{|c|c|c|c|c|c|c|c|c|}
\hline & \multicolumn{3}{|c|}{$\begin{array}{l}\text { PPP borrowers } \\
\quad(\mathrm{N}=678)\end{array}$} & \multicolumn{3}{|c|}{$\begin{array}{l}\text { Non-applicants } \\
\quad(\mathrm{N}=1,600)\end{array}$} & \multicolumn{2}{|c|}{$\begin{array}{l}\text { Difference } \\
\text { tests }\end{array}$} \\
\hline & Mean & Median & $\mathrm{SD}$ & Mean & Median & $\mathrm{SD}$ & $\mathrm{N}$ & $\mathrm{p}$-value \\
\hline & (1) & $(2)$ & (3) & $(4)$ & (5) & (6) & (7) & (8) \\
\hline \multicolumn{9}{|c|}{ Panel A: Firm size } \\
\hline PPP Loan Amount (\$ million) & 2.354 & 1.064 & 3.098 & - & - & - & 678 & - \\
\hline Book Value of Assets ( $\$$ million) & 109.3 & 34.8 & 472.0 & 482.0 & 74.3 & $1,426.0$ & 2,153 & 0.000 \\
\hline Market Cap (\$ million) & 102.6 & 35.4 & 257.7 & 446.7 & 102.5 & 900.1 & 2,076 & 0.000 \\
\hline Sales (\$ million) & 81.0 & 23.2 & 187.5 & 113.1 & 11.8 & 286.4 & 2,153 & 0.000 \\
\hline \# Employees ('000) & 0.244 & 0.090 & 0.381 & 0.113 & 0.056 & 0.131 & 2,145 & 0.000 \\
\hline \multicolumn{9}{|c|}{ Panel B: Other financial characteristics } \\
\hline Firm Age (years) & 16.014 & 12.000 & 12.913 & 10.111 & 7.000 & 10.035 & 2,153 & 0.000 \\
\hline Book Equity <0 $(1 / 0)$ & $22.6 \%$ & - & - & $17.4 \%$ & - & - & 2,151 & 0.000 \\
\hline Tobin's Q & 1.669 & 1.135 & 2.194 & 2.599 & 1.315 & 4.114 & 2,153 & 0.000 \\
\hline Sales Growth & 0.544 & 0.023 & 3.030 & 0.691 & 0.039 & 3.231 & 1,652 & 0.728 \\
\hline Dividend Payer (1/0) & $14.3 \%$ & - & - & $13.9 \%$ & - & - & 2,153 & 0.619 \\
\hline Current Ratio & 2.562 & 1.616 & 3.745 & 4.874 & 2.344 & 7.143 & 2,134 & 0.000 \\
\hline Cash/Non-Cash Assets & 1.050 & 0.221 & 3.217 & 3.359 & 0.365 & 7.668 & 2,138 & 0.000 \\
\hline Free Cash Flow/Assets & 0.238 & 0.043 & 1.614 & 0.392 & 0.012 & 2.724 & 1,792 & 0.000 \\
\hline \multicolumn{9}{|c|}{ Panel C: Financial constraints } \\
\hline Has Credit Rating (1/0) & $2.2 \%$ & - & - & $5.4 \%$ & - & - & 2,278 & 0.000 \\
\hline WW Index $\geq \mathrm{p} 75(1 / 0)$ & $71.7 \%$ & - & - & $50.1 \%$ & - & - & 1,338 & 0.000 \\
\hline SA Index $\geq$ p $75(1 / 0)$ & $77.2 \%$ & - & - & $73.8 \%$ & - & - & 1,972 & 0.387 \\
\hline \multicolumn{9}{|c|}{ Panel D: Leverage and distress } \\
\hline Zero Debt $(1 / 0)$ & $9.8 \%$ & - & - & $15.3 \%$ & - & - & 2,150 & 0.000 \\
\hline Market Leverage & 0.259 & 0.178 & 0.254 & 0.229 & 0.104 & 0.270 & 1,787 & 0.000 \\
\hline Interest Coverage $<1.5(1 / 0)$ & $79.5 \%$ & - & - & $76.9 \%$ & - & - & 1,564 & 0.554 \\
\hline Altman Z-score $<1.81(1 / 0)$ & $69.6 \%$ & - & - & $61.0 \%$ & - & - & 1,739 & 0.018 \\
\hline Distance-to-Default & 2.649 & 2.216 & 2.097 & 3.589 & 3.033 & 2.426 & 1,013 & 0.000 \\
\hline Penny Stock (1/0) & $75.5 \%$ & - & - & $61.3 \%$ & - & - & 2,077 & 0.000 \\
\hline \multicolumn{9}{|c|}{ Panel E: Stock returns } \\
\hline Covid Period Return & -0.325 & -0.400 & 0.392 & -0.319 & -0.358 & 0.328 & 2,157 & 0.005 \\
\hline Stimulus Day Return & 0.056 & 0.039 & 0.115 & 0.058 & 0.048 & 0.102 & 2,170 & 0.079 \\
\hline
\end{tabular}




\section{Table III \\ PPP borrowing propensity}

This table reports the results from a linear probability (OLS) model where the dependent variable is an indicator for public company receiving a PPP loan and independent variables are company characteristics. Continuous variables are winsorized at the $1^{\text {st }}$ and the $99^{\text {th }}$ percentiles. Standard errors are clustered at the industry level, defined as 2-digit NAICS, where we combine industries with few PPP-eligible companies into one bucket. ${ }^{* * *},{ }^{* *}$, and ${ }^{*}$ denote statistical significance at the $1 \%, 5 \%$, and $10 \%$ levels, respectively. $t$-statistics are presented in parentheses.

\begin{tabular}{|c|c|c|c|}
\hline & \multicolumn{3}{|c|}{ Dependent variable $=$ PPP Borrower $(1 / 0)$} \\
\hline & (1) & $(2)$ & $(3)$ \\
\hline Log (Assets) & $\begin{array}{c}-0.0300^{* * *} \\
(-3.55)\end{array}$ & $\begin{array}{c}-0.0232^{* * *} \\
(-4.42)\end{array}$ & $\begin{array}{c}-0.0239 * * * \\
(-3.85)\end{array}$ \\
\hline Log (Age) & $\begin{array}{c}0.0673^{* * *} \\
(3.58)\end{array}$ & $\begin{array}{c}0.0654^{* *} \\
(2.85)\end{array}$ & $\begin{array}{c}0.0665^{* *} \\
(2.78)\end{array}$ \\
\hline Book Equity <0 (1/0) & $\begin{array}{c}-0.0689^{*} \\
(-1.94)\end{array}$ & $\begin{array}{c}-0.0655 \\
(-1.73)\end{array}$ & $\begin{array}{c}-0.0678 \\
(-1.64)\end{array}$ \\
\hline Tobin's Q & $\begin{array}{c}-0.0119^{* * *} \\
(-6.22)\end{array}$ & $\begin{array}{c}-0.0109^{* * *} \\
(-5.47)\end{array}$ & $\begin{array}{c}-0.0106^{* * *} \\
(-4.31)\end{array}$ \\
\hline Current Ratio & $\begin{array}{c}-0.00701^{* * *} \\
(-4.46)\end{array}$ & $\begin{array}{c}-0.00623^{* * *} \\
(-4.18)\end{array}$ & $\begin{array}{c}-0.00591 * * * \\
(-4.03)\end{array}$ \\
\hline Cash/Non-Cash Assets & $\begin{array}{c}-0.00468^{* * *} \\
(-3.11)\end{array}$ & $\begin{array}{c}-0.00459^{* *} \\
(-2.39)\end{array}$ & $\begin{array}{c}-0.00455^{* *} \\
(-2.25)\end{array}$ \\
\hline Penny Stock $(1 / 0)$ & $\begin{array}{c}0.00219 \\
(0.05)\end{array}$ & $\begin{array}{c}0.00890 \\
(0.27)\end{array}$ & $\begin{array}{r}0.0647 \\
(1.48)\end{array}$ \\
\hline Covid Industry (1/0) & & $\begin{array}{c}0.274^{* *} \\
(2.68)\end{array}$ & $\begin{array}{c}0.276^{* *} \\
(2.64)\end{array}$ \\
\hline Machinery Industry $(1 / 0)$ & & $\begin{array}{l}0.163 \\
(1.60)\end{array}$ & $\begin{array}{l}0.168 \\
(1.45)\end{array}$ \\
\hline Health Industry $(1 / 0)$ & & $\begin{array}{c}0.0266 \\
(0.29)\end{array}$ & $\begin{array}{r}0.0317 \\
(0.33)\end{array}$ \\
\hline High-Tech Industry $(1 / 0)$ & & $\begin{array}{l}0.109 \\
(1.02)\end{array}$ & $\begin{array}{l}0.119 \\
(1.15)\end{array}$ \\
\hline Covid Period Return & & & $\begin{array}{c}-0.138^{*} \\
(-2.10)\end{array}$ \\
\hline Covid Period Return $\times$ Penny Stock $(1 / 0)$ & & & $\begin{array}{l}0.123^{*} \\
(1.90)\end{array}$ \\
\hline Stimulus Day Return & & & $\begin{array}{l}0.179 \\
(0.47)\end{array}$ \\
\hline Stimulus Day Return $\times$ Penny Stock $(1 / 0)$ & & & $\begin{array}{l}0.0315 \\
(0.08)\end{array}$ \\
\hline \# obs. & 1,917 & 1,917 & 1,877 \\
\hline Adjusted $\mathrm{R}^{2}$ & 0.0730 & 0.0968 & 0.100 \\
\hline
\end{tabular}




\section{Table IV \\ Financial constraints, solvency, and PPP borrowing}

This table reports the results from a linear probability (OLS) model where the dependent variable is an indicator for public company receiving a PPP loan and independent variables are financial constraints and solvency indexes. Continuous variables are winsorized at the $1^{\text {st }}$ and the $99^{\text {th }}$ percentiles. Standard errors are clustered at the industry level, defined as 2-digit NAICS, where we combine industries with few PPP-eligible companies into one bucket. ${ }^{* * *}$, **, and $*$ denote statistical significance at the $1 \%, 5 \%$, and $10 \%$ levels, respectively. $t$-statistics are presented in parentheses.

\begin{tabular}{|c|c|c|c|c|c|c|c|c|c|}
\hline & \multicolumn{9}{|c|}{ Dependent variable $=\mathrm{PPP}$ Borrower $(1 / 0)$} \\
\hline & (1) & $(2)$ & $(3)$ & $(4)$ & $(5)$ & (6) & (7) & $(8)$ & (9) \\
\hline WW Index $\geq$ p75 (1/0) & $\begin{array}{l}0.149^{* * *} \\
(3.77)\end{array}$ & $\begin{array}{l}0.147^{* * *} \\
(5.28)\end{array}$ & $\begin{array}{l}0.146^{* * *} \\
(4.48)\end{array}$ & & & & & & \\
\hline SA Index $\geq$ p75 (1/0) & & & & $\begin{array}{c}0.00421 \\
(0.09)\end{array}$ & $\begin{array}{c}0.0132 \\
(0.36)\end{array}$ & $\begin{array}{c}0.00766 \\
(0.22)\end{array}$ & & & \\
\hline Altman Z-score $<1.81(1 / 0)$ & & & & & & & $\begin{array}{c}0.0350 \\
(1.36)\end{array}$ & $\begin{array}{c}0.0390 \\
(1.32)\end{array}$ & $\begin{array}{l}0.0368 \\
(1.30)\end{array}$ \\
\hline Penny Stock Dummy & Yes & Yes & Yes & Yes & Yes & Yes & Yes & Yes & Yes \\
\hline Industry Dummies & - & Yes & Yes & - & Yes & Yes & - & Yes & Yes \\
\hline Returns Controls & - & - & Yes & - & - & Yes & - & - & Yes \\
\hline \# obs. & 1,287 & 1,287 & 1,258 & 1,904 & 1,904 & 1,867 & 1,739 & 1,739 & 1,703 \\
\hline Adjusted $R^{2}$ & 0.0496 & 0.0810 & 0.0915 & 0.0195 & 0.0590 & 0.0645 & 0.0136 & 0.0565 & 0.0644 \\
\hline
\end{tabular}




\section{Table V \\ PPP loan grant announcement effects}

This table reports the results from a event study analysis where the dependent variable is the company's stock return measured as stock return minus S\&P 500 return (Panel A) or abnormal stock return calculated using the market model based on S\&P 500 return (Panel B). The key independent variable Day is an indicator for the treading day relative to the PPP loan grant announcement date, Day 0 (e.g., 8-K filing, press release). The time period is from Day -60 to Day +1 . The estimation window for the market model is Day -270 to Day -61 . The day count excludes non-trading days (e.g., weekends, holidays). Continuous variables are winsorized at the $1^{\text {st }}$ and the $99^{\text {th }}$ percentiles. Standard errors are clustered at the trading day level. ***,**, and * denote statistical significance at the $1 \%, 5 \%$, and $10 \%$ levels, respectively. $t$-statistics are presented in parentheses.

\begin{tabular}{|c|c|c|c|c|c|c|}
\hline & \multicolumn{3}{|c|}{ Panel A: Market-adjusted } & \multicolumn{3}{|c|}{ Panel B: Market model } \\
\hline & Day -1 & Day 0 & Day +1 & Day -1 & Day 0 & Day +1 \\
\hline & (1) & $(2)$ & $(3)$ & $(4)$ & $(5)$ & (6) \\
\hline \multicolumn{7}{|c|}{ Panel A: All observations } \\
\hline \multicolumn{7}{|l|}{ Across firms: } \\
\hline $\begin{array}{l}\text { Abnormal return } \\
\text { t-statistic }\end{array}$ & $\begin{array}{c}0.0106^{* *} \\
(2.59)\end{array}$ & $\begin{array}{c}0.00386 \\
(0.85)\end{array}$ & $\begin{array}{c}0.000889 \\
(0.19)\end{array}$ & $\begin{array}{c}0.0108^{* * *} \\
(2.94)\end{array}$ & $\begin{array}{c}0.00577 \\
(1.30)\end{array}$ & $\begin{array}{c}0.00396 \\
(0.96)\end{array}$ \\
\hline \multicolumn{7}{|l|}{ Within firms: } \\
\hline $\begin{array}{l}\text { Abnormal return } \\
\text { t-statistic }\end{array}$ & $\begin{array}{c}0.0107^{* *} \\
(2.54)\end{array}$ & $\begin{array}{c}0.00387 \\
(0.84)\end{array}$ & $\begin{array}{l}0.000898 \\
(0.19)\end{array}$ & $\begin{array}{c}0.0108^{* * *} \\
(2.90)\end{array}$ & $\begin{array}{c}0.00579 \\
(1.28)\end{array}$ & $\begin{array}{c}0.00398 \\
(0.95)\end{array}$ \\
\hline \multicolumn{7}{|c|}{ Panel B: Only 8-K filings } \\
\hline \multicolumn{7}{|l|}{ Across firms: } \\
\hline $\begin{array}{l}\text { Abnormal return } \\
\text { t-statistic }\end{array}$ & $\begin{array}{c}0.0154^{* * *} \\
(3.58)\end{array}$ & $\begin{array}{c}0.00567 \\
(0.96)\end{array}$ & $\begin{array}{c}0.00684 \\
(1.30)\end{array}$ & $\begin{array}{c}0.0152^{* * *} \\
(3.77)\end{array}$ & $\begin{array}{c}0.00777 \\
(1.33)\end{array}$ & $\begin{array}{c}0.00849^{*} \\
(1.69)\end{array}$ \\
\hline \multicolumn{7}{|l|}{ Within firms: } \\
\hline $\begin{array}{l}\text { Abnormal return } \\
\text { t-statistic }\end{array}$ & $\begin{array}{c}0.0154^{* * *} \\
(3.59)\end{array}$ & $\begin{array}{c}0.00569 \\
(0.94)\end{array}$ & $\begin{array}{c}0.00686 \\
(1.31)\end{array}$ & $\begin{array}{l}0.0152^{* * *} \\
\quad(3.78)\end{array}$ & $\begin{array}{c}0.00780 \\
(1.32)\end{array}$ & $\begin{array}{c}0.00852^{*} \\
(1.72)\end{array}$ \\
\hline \multicolumn{7}{|c|}{ Panel C: Only 8-K filings \& non-penny stocks } \\
\hline \multicolumn{7}{|l|}{ Across firms: } \\
\hline $\begin{array}{l}\text { Abnormal return } \\
\text { t-statistic }\end{array}$ & $\begin{array}{c}0.0164^{* * *} \\
(2.90)\end{array}$ & $\begin{array}{c}0.00665 \\
(0.86)\end{array}$ & $\begin{array}{c}0.00875 \\
(1.18)\end{array}$ & $\begin{array}{c}0.0151^{* *} \\
(2.57)\end{array}$ & $\begin{array}{c}0.00997 \\
(1.16)\end{array}$ & $\begin{array}{c}0.0103 \\
(1.35)\end{array}$ \\
\hline \multicolumn{7}{|l|}{ Within firms: } \\
\hline $\begin{array}{l}\text { Abnormal return } \\
\text { t-statistic }\end{array}$ & $\begin{array}{c}0.0164^{* * *} \\
(2.89)\end{array}$ & $\begin{array}{c}0.00666 \\
(0.87)\end{array}$ & $\begin{array}{c}0.00876 \\
(1.14)\end{array}$ & $\begin{array}{c}0.0152^{* * *} \\
(2.63)\end{array}$ & $\begin{array}{c}0.0100 \\
(1.15)\end{array}$ & $\begin{array}{c}0.0103 \\
(1.31)\end{array}$ \\
\hline
\end{tabular}




\section{Table VI \\ Public PPP returners versus retainers}

Columns (1) to (3) report the mean, median, and standard deviation of several financial characteristics of firms that returned PPP loans to SBA. Columns (4) to (6) report the same statistics for firms that retained PPP loans. Column (7) reports the number of observations and Column (8) reports p-values from a Wilcoxon rank sum test comparing returners with retainers. In the case of discrete variables, the statistics are proportions and the p-values are for tests of the difference in proportions. Continuous variables are winsorized at the $1^{\text {st }}$ and the $99^{\text {th }}$ percentiles.

\begin{tabular}{|c|c|c|c|c|c|c|c|c|}
\hline & \multicolumn{3}{|c|}{$\begin{array}{l}\text { Returned PPP loan } \\
\qquad(\mathrm{N}=104)\end{array}$} & \multicolumn{3}{|c|}{$\begin{array}{l}\text { Retained PPP loan } \\
\qquad(\mathrm{N}=574)\end{array}$} & \multicolumn{2}{|c|}{$\begin{array}{l}\text { Difference } \\
\text { tests }\end{array}$} \\
\hline & Mean & Median & $\mathrm{SD}$ & Mean & Median & $\mathrm{SD}$ & $\mathrm{N}$ & p-value \\
\hline & (1) & $(2)$ & $(3)$ & $(4)$ & $(5)$ & (6) & $(7)$ & $(8)$ \\
\hline \multicolumn{9}{|c|}{ Panel A: Firm size } \\
\hline PPP Loan Amount ( $\$$ million) & 4.581 & 3.541 & 4.235 & 1.950 & 0.900 & 2.655 & 678 & 0.000 \\
\hline Book Value of Assets ( $\$$ million) & 299.2 & 87.0 & $1,069.0$ & 67.4 & 28.4 & 109.9 & 553 & 0.000 \\
\hline Market Cap (\$ million) & 258.4 & 118.0 & 517.3 & 68.2 & 27.4 & 126.6 & 548 & 0.000 \\
\hline Sales (\$ million) & 165.3 & 53.1 & 333.8 & 62.4 & 19.3 & 128.9 & 553 & 0.000 \\
\hline \# Employees ('000) & 0.404 & 0.224 & 0.481 & 0.209 & 0.076 & 0.346 & 545 & 0.000 \\
\hline \multicolumn{9}{|c|}{ Panel B: Other financial characteristics } \\
\hline Firm Age (years) & 18.030 & 13.500 & 14.875 & 15.570 & 12.000 & 12.413 & 553 & 0.361 \\
\hline Book Equity <0 (1/0) & $9.0 \%$ & - & - & $25.7 \%$ & - & - & 552 & 0.000 \\
\hline Tobin's Q & 2.175 & 1.474 & 2.791 & 1.558 & 1.051 & 2.026 & 553 & 0.000 \\
\hline Sales Growth & 0.491 & 0.071 & 2.847 & 0.556 & 0.013 & 3.074 & 496 & 0.029 \\
\hline Dividend Payer (1/0) & $23.0 \%$ & - & - & $12.4 \%$ & - & - & 553 & 0.000 \\
\hline Current Ratio & 3.785 & 2.238 & 5.051 & 2.290 & 1.427 & 3.336 & 551 & 0.000 \\
\hline Cash/Non-Cash Assets & 1.063 & 0.446 & 1.644 & 1.047 & 0.169 & 3.471 & 553 & 0.001 \\
\hline Free Cash Flow/Assets & 0.140 & 0.018 & 1.161 & 0.258 & 0.055 & 1.694 & 465 & 0.051 \\
\hline \multicolumn{9}{|c|}{ Panel C: Financial constraints } \\
\hline Has Credit Rating (1/0) & $6.7 \%$ & - & 一 & $1.4 \%$ & - & - & 678 & 0.000 \\
\hline WW Index $\geq$ p75 (1/0) & $50.7 \%$ & - & - & $76.3 \%$ & - & - & 389 & 0.001 \\
\hline SA Index $\geq$ p75 (1/0) & $61.5 \%$ & - & - & $80.7 \%$ & - & - & 501 & 0.012 \\
\hline \multicolumn{9}{|c|}{ Panel D: Leverage and distress } \\
\hline Zero Debt $(1 / 0)$ & $11.0 \%$ & - & - & $9.5 \%$ & - & - & 553 & 0.205 \\
\hline Market Leverage & 0.192 & 0.116 & 0.204 & 0.273 & 0.198 & 0.261 & 495 & 0.006 \\
\hline Interest Coverage $<1.5(1 / 0)$ & $62.9 \%$ & - & - & $82.8 \%$ & - & - & 430 & 0.022 \\
\hline Altman Z-score $<1.81(1 / 0)$ & $49.4 \%$ & - & - & $74.0 \%$ & - & - & 471 & 0.000 \\
\hline Distance-to-Default & 3.747 & 2.990 & 2.362 & 2.339 & 1.951 & 1.909 & 391 & 0.000 \\
\hline Penny Stock $(1 / 0)$ & $52.5 \%$ & - & - & $80.6 \%$ & - & - & 548 & 0.000 \\
\hline \multicolumn{9}{|c|}{ Panel E: Stock returns } \\
\hline Covid Period Return & -0.359 & -0.418 & 0.328 & -0.318 & -0.399 & 0.403 & 629 & 0.648 \\
\hline Stimulus Day Return & 0.071 & 0.062 & 0.095 & 0.053 & 0.035 & 0.119 & 633 & 0.029 \\
\hline PPP Grant Abnormal Return & 0.032 & 0.019 & 0.107 & 0.023 & 0.001 & 0.141 & 634 & 0.134 \\
\hline
\end{tabular}




\section{Table VII \\ PPP loan repayment propensity}

This table reports the results from a linear probability (OLS) model where the dependent variable is an indicator for public company returning a PPP loan to the SBA and independent variables are company characteristics. Continuous variables are winsorized at the $1^{\text {st }}$ and the $99^{\text {th }}$ percentiles. Standard errors are clustered at the industry level, defined as 2-digit NAICS, where we combine industries with few PPP-eligible companies into one bucket. ***, **, and $*$ denote statistical significance at the $1 \%, 5 \%$, and $10 \%$ levels, respectively. $t$-statistics are presented in parentheses.

\begin{tabular}{|c|c|c|c|}
\hline & \multicolumn{3}{|c|}{ Dependent variable $=$ PPP Loan Returner $(1 / 0)$} \\
\hline & (1) & $(2)$ & $(3)$ \\
\hline Log (Assets) & $\begin{array}{c}0.0518^{* * * *} \\
(3.23)\end{array}$ & $\begin{array}{c}0.0492^{* * *} \\
(3.28)\end{array}$ & $\begin{array}{c}0.0509^{* * *} \\
(3.09)\end{array}$ \\
\hline Log (Age) & $\begin{array}{c}-0.0176 \\
(-1.14)\end{array}$ & $\begin{array}{c}-0.00894 \\
(-0.61)\end{array}$ & $\begin{array}{c}-0.0113 \\
(-0.78)\end{array}$ \\
\hline Book Equity <0 (1/0) & $\begin{array}{c}0.0166 \\
(0.29)\end{array}$ & $\begin{array}{c}0.00630 \\
(0.13)\end{array}$ & $\begin{array}{c}0.00670 \\
(0.16)\end{array}$ \\
\hline Tobin's Q & $\begin{array}{c}0.0124^{* *} \\
(2.81)\end{array}$ & $\begin{array}{c}0.00806^{*} \\
(1.93)\end{array}$ & $\begin{array}{c}0.00583 \\
(1.23)\end{array}$ \\
\hline Current Ratio & $\begin{array}{c}0.0115^{* * *} \\
(6.31)\end{array}$ & $\begin{array}{c}0.0106^{* * *} \\
(5.44)\end{array}$ & $\begin{array}{c}0.0105^{* * *} \\
(6.35)\end{array}$ \\
\hline Cash/Non-Cash Assets & $\begin{array}{c}-0.000614 \\
(-0.28)\end{array}$ & $\begin{array}{c}-0.00171 \\
(-0.73)\end{array}$ & $\begin{array}{c}-0.00133 \\
(-0.57)\end{array}$ \\
\hline Penny Stock $(1 / 0)$ & $\begin{array}{c}-0.120^{* *} \\
(-2.66)\end{array}$ & $\begin{array}{c}-0.128^{* * *} \\
(-3.12)\end{array}$ & $\begin{array}{c}-0.268^{* *} \\
(-2.75)\end{array}$ \\
\hline Covid Industry (1/0) & & $\begin{array}{c}-0.0543^{*} \\
(-2.08)\end{array}$ & $\begin{array}{c}-0.0630^{* *} \\
(-2.33)\end{array}$ \\
\hline Machinery Industry $(1 / 0)$ & & $\begin{array}{c}-0.0781^{* * *} \\
(-3.43)\end{array}$ & $\begin{array}{c}-0.0983^{* * *} \\
(-3.81)\end{array}$ \\
\hline Health Industry (1/0) & & $\begin{array}{c}0.0859^{* *} \\
(2.34)\end{array}$ & $\begin{array}{c}0.0787^{* *} \\
(2.29)\end{array}$ \\
\hline High-Tech Industry $(1 / 0)$ & & $\begin{array}{c}-0.0412 \\
(-1.31)\end{array}$ & $\begin{array}{c}-0.0478 \\
(-1.38)\end{array}$ \\
\hline Covid Period Return & & & $\begin{array}{c}0.379^{* *} \\
(2.56)\end{array}$ \\
\hline Covid Period Return $\times$ Penny Stock $(1 / 0)$ & & & $\begin{array}{c}-0.348^{*} \\
(-2.01)\end{array}$ \\
\hline Stimulus Day Return & & & $\begin{array}{l}0.146 \\
(0.48)\end{array}$ \\
\hline Stimulus Day Return × Penny Stock (1/0) & & & $\begin{array}{l}-0.145 \\
(-0.56)\end{array}$ \\
\hline PPP Grant Abnormal Return & & & $\begin{array}{l}0.165 \\
(0.47)\end{array}$ \\
\hline PPP Grant Abnormal Return $\times$ Penny Stock $(1 / 0)$ & & & $\begin{array}{c}-0.0323 \\
(-0.08)\end{array}$ \\
\hline \# obs. & 530 & 530 & 522 \\
\hline Adjusted $\mathrm{R}^{2}$ & 0.105 & 0.116 & 0.120 \\
\hline
\end{tabular}




\section{Table VIII \\ Financial constraints, solvency, and PPP loan repayment}

This table reports the results from a linear probability (OLS) model where the dependent variable is an indicator for public company returning a PPP loan to the SBA and independent variables are financial constraints and solvency indexes. Continuous variables are winsorized at the $1^{\text {st }}$ and the $99^{\text {th }}$ percentiles. Standard errors are clustered at the industry level, defined as 2-digit NAICS, where we combine industries with few PPP-eligible companies into one bucket. ***, **, and * denote statistical significance at the $1 \%, 5 \%$, and $10 \%$ levels, respectively. $t$-statistics are presented in parentheses.

\begin{tabular}{|c|c|c|c|c|c|c|c|c|c|}
\hline & \multicolumn{9}{|c|}{ Dependent variable $=$ PPP Loan Returner $(1 / 0)$} \\
\hline $\begin{array}{l}\text { WW Index } \\
\quad \geq \text { p75 }(1 / 0)\end{array}$ & $\begin{array}{c}-0.132^{* * *} \\
(-3.76)\end{array}$ & $\begin{array}{c}-0.129^{* * *} \\
(-3.95)\end{array}$ & $\begin{array}{c}-0.125^{* * *} \\
(-3.48)\end{array}$ & & & & & & \\
\hline $\begin{array}{l}\text { SA Index } \\
\qquad \geq \mathrm{p} 75(1 / 0)\end{array}$ & & & & $\begin{array}{c}-0.109^{* * *} \\
(-3.34)\end{array}$ & $\begin{array}{c}-0.123^{* * *} \\
(-3.03)\end{array}$ & $\begin{array}{c}-0.113^{* *} \\
(-2.75)\end{array}$ & & & \\
\hline $\begin{array}{c}\text { Altman Z-score } \\
<1.81(1 / 0)\end{array}$ & & & & & & & $\begin{array}{c}-0.0786^{* *} \\
(-2.31)\end{array}$ & $\begin{array}{c}-0.0939^{* *} \\
(-2.67)\end{array}$ & $\begin{array}{c}-0.0954^{* *} \\
(-2.96)\end{array}$ \\
\hline Industry Dummies & - & Yes & Yes & - & Yes & Yes & - & Yes & Yes \\
\hline Returns Controls & - & - & Yes & - & - & Yes & - & - & Yes \\
\hline \# obs. & 386 & 386 & 378 & 496 & 496 & 488 & 471 & 471 & 465 \\
\hline Adjusted $\mathrm{R}^{2}$ & 0.0743 & 0.102 & 0.101 & 0.0585 & 0.0813 & 0.0854 & 0.0732 & 0.103 & 0.102 \\
\hline
\end{tabular}




\section{Table IX \\ Regression discontinuity (RD) analysis of PPP loan repayment}

This table reports the results from an RD analysis of PPP loan repayment decision based on loan size threshold of $\$ 2$ million, controlling for the distance from the threshold. Panel A reports the results of regressions without controls. Panel B includes the full set of controls. Panel C reports the results of local RD analysis. Continuous variables are winsorized at the $1^{\text {st }}$ and the $99^{\text {th }}$ percentiles. Standard errors are clustered at the industry level, defined as 2-digit NAICS, where we combine industries with few PPP-eligible companies into one bucket. ***, **, and ${ }^{*}$ denote statistical significance at the $1 \%, 5 \%$, and $10 \%$ levels, respectively. $t$-statistics are presented in parentheses.

\begin{tabular}{|c|c|c|c|c|}
\hline & \multicolumn{4}{|c|}{ Dependent variable $=$ PPP Loan Returner $(1 / 0)$} \\
\hline & $(1)$ & $(2)$ & $(3)$ & $(4)$ \\
\hline \multicolumn{5}{|c|}{ Panel A: All loans } \\
\hline Above $\$ 2 \mathrm{M}(1 / 0)$ & $\begin{array}{c}0.119^{* * *} \\
(3.56)\end{array}$ & $\begin{array}{c}0.0845 \\
(1.73)\end{array}$ & $\begin{array}{c}0.0941^{*} \\
(1.90)\end{array}$ & $\begin{array}{c}0.149^{* *} \\
(2.64)\end{array}$ \\
\hline Distance & $\begin{array}{c}0.0135^{* * *} \\
(4.24)\end{array}$ & $\begin{array}{c}0.0216^{* *} \\
(2.43)\end{array}$ & $\begin{array}{c}0.0349 \\
(1.15)\end{array}$ & $\begin{array}{c}-0.176^{* * *} \\
(-3.15)\end{array}$ \\
\hline Above $\$ 2 \mathrm{M}(1 / 0) \times$ Distance & & & $\begin{array}{c}-0.0217 \\
(-0.70)\end{array}$ & $\begin{array}{c}0.197^{* * *} \\
(3.40)\end{array}$ \\
\hline Distance $^{2}$ & & $\begin{array}{c}-0.000150 \\
(-1.34)\end{array}$ & & $\begin{array}{c}-0.0995^{* * *} \\
\quad(-5.92)\end{array}$ \\
\hline Above $\$ 2 \mathrm{M}(1 / 0) \times$ Distance $^{2}$ & & & & $\begin{array}{c}0.0994^{* * *} \\
(5.91)\end{array}$ \\
\hline \# obs. & 553 & 553 & 553 & 553 \\
\hline Adjusted $\mathrm{R}^{2}$ & 0.0732 & 0.0737 & 0.0721 & 0.0741 \\
\hline \multicolumn{5}{|c|}{ Panel B: All loans + controls } \\
\hline Above $\$ 2 \mathrm{M}(1 / 0)$ & $\begin{array}{c}0.0614^{*} \\
(2.05)\end{array}$ & $\begin{array}{c}0.0258 \\
(0.74)\end{array}$ & $\begin{array}{c}0.0770 \\
(1.47)\end{array}$ & $\begin{array}{l}0.0985^{* *} \\
(2.21)\end{array}$ \\
\hline Distance & $\begin{array}{l}0.0121^{* * *} \\
\quad(3.31)\end{array}$ & $\begin{array}{l}0.0223^{* *} \\
(2.95)\end{array}$ & $\begin{array}{c}-0.00666 \\
(-0.15)\end{array}$ & $\begin{array}{l}-0.143 \\
(-1.52)\end{array}$ \\
\hline Above $\$ 2 \mathrm{M}(1 / 0) \times$ Distance & & & $\begin{array}{r}0.0186 \\
(0.44)\end{array}$ & $\begin{array}{l}0.166 \\
(1.76)\end{array}$ \\
\hline Distance $^{2}$ & & $\begin{array}{c}-0.000179 * \\
(-1.95)\end{array}$ & & $\begin{array}{c}-0.0684 \\
(-1.66)\end{array}$ \\
\hline Above $\$ 2 \mathrm{M}(1 / 0) \times$ Distance $^{2}$ & & & & $\begin{array}{c}0.0682 \\
(1.65)\end{array}$ \\
\hline Firm Characteristics & Yes & Yes & Yes & Yes \\
\hline Penny Stock Dummy & Yes & Yes & Yes & Yes \\
\hline Industry Dummies & Yes & Yes & Yes & Yes \\
\hline Returns Controls & Yes & Yes & Yes & Yes \\
\hline \# obs. & 522 & 522 & 522 & 522 \\
\hline Adjusted $\mathrm{R}^{2}$ & 0.138 & 0.139 & 0.136 & 0.138 \\
\hline \multicolumn{5}{|c|}{ Panel C: Loans of $\$ 1 \mathrm{M}$ to $\$ 3 \mathrm{M}$} \\
\hline Above $\$ 2 \mathrm{M}(1 / 0)$ & $\begin{array}{c}0.156^{* *} \\
(2.59)\end{array}$ & $\begin{array}{c}0.159^{* *} \\
(2.60)\end{array}$ & $\begin{array}{c}0.157^{* *} \\
(2.55)\end{array}$ & $\begin{array}{l}0.194 \\
(1.10)\end{array}$ \\
\hline Distance & $\begin{array}{c}-0.133^{* * *} \\
(-3.84)\end{array}$ & $\begin{array}{c}-0.137^{* * *} \\
(-4.57)\end{array}$ & $\begin{array}{c}-0.131^{* *} \\
(-2.38)\end{array}$ & $\begin{array}{l}-0.303 \\
(-1.46)\end{array}$ \\
\hline Above $\$ 2 \mathrm{M}(1 / 0)$ x Distance & & & $\begin{array}{c}-0.00770 \\
(-0.09)\end{array}$ & $\begin{array}{l}0.104 \\
(0.17)\end{array}$ \\
\hline Distance $^{2}$ & & $\begin{array}{c}-0.0106 \\
(-0.23)\end{array}$ & & $\begin{array}{l}-0.167 \\
(-0.96)\end{array}$ \\
\hline Above $\$ 2 \mathrm{M}(1 / 0) \times$ Distance $^{2}$ & & & & $\begin{array}{l}0.228 \\
(0.26)\end{array}$ \\
\hline \# obs. & 176 & 176 & 176 & 176 \\
\hline Adjusted $\mathrm{R}^{2}$ & 0.00291 & -0.00281 & -0.00288 & -0.0136 \\
\hline
\end{tabular}




\section{Table X \\ PPP loan repayment announcement effects}

This table reports the results from a event study analysis where the dependent variable is the company's stock return measured as stock return minus S\&P 500 return (Panel A) or abnormal stock return calculated using the market model based on S\&P 500 return (Panel B). The key independent variable Day is an indicator for the treading day relative to the PPP loan return announcement date, Day 0 (e.g., 8-K filing, press release). The time period is from Day -60 to Day 1. The estimation window for the market model is Day -270 to Day -61 . The day count excludes non-trading days (e.g., weekends, holidays). Continuous variables are winsorized at the $1^{\text {st }}$ and the $99^{\text {th }}$ percentiles. Standard errors are clustered at the trading day level. $* * *, * *$, and $*$ denote statistical significance at the $1 \%, 5 \%$, and $10 \%$ levels, respectively. $t$-statistics are presented in parentheses.

\begin{tabular}{|c|c|c|c|c|c|c|}
\hline & \multicolumn{3}{|c|}{ Panel A: Market-adjusted } & \multicolumn{3}{|c|}{ Panel B: Market model } \\
\hline & Day -1 & Day 0 & Day +1 & Day -1 & Day 0 & Day +1 \\
\hline & $(1)$ & $(2)$ & $(3)$ & $(4)$ & $(5)$ & $(6)$ \\
\hline \multicolumn{7}{|c|}{ Panel A: All observations } \\
\hline \multicolumn{7}{|l|}{ Across firms: } \\
\hline $\begin{array}{l}\text { Abnormal return } \\
\text { t-statistic }\end{array}$ & $\begin{array}{c}-0.00769 \\
(-1.15)\end{array}$ & $\begin{array}{c}0.0250^{* * *} \\
(3.14)\end{array}$ & $\begin{array}{c}0.000436 \\
(0.06)\end{array}$ & $\begin{array}{c}-0.00864 \\
(-1.22)\end{array}$ & $\begin{array}{c}0.0259^{* * *} \\
(3.14)\end{array}$ & $\begin{array}{c}-0.000251 \\
(-0.03)\end{array}$ \\
\hline \multicolumn{7}{|l|}{ Within firms: } \\
\hline $\begin{array}{l}\text { Abnormal return } \\
\text { t-statistic }\end{array}$ & $\begin{array}{c}-0.00766 \\
(-1.12)\end{array}$ & $\begin{array}{c}0.0250^{* * *} \\
(3.21)\end{array}$ & $\begin{array}{c}-0.000648 \\
(-0.09)\end{array}$ & $\begin{array}{c}-0.00862 \\
(-1.19)\end{array}$ & $\begin{array}{c}0.0259^{* * *} \\
(3.24)\end{array}$ & $\begin{array}{c}-0.000236 \\
(-0.03)\end{array}$ \\
\hline \multicolumn{7}{|c|}{ Panel B: Only 8-K filings } \\
\hline \multicolumn{7}{|l|}{ Across firms: } \\
\hline $\begin{array}{l}\text { Abnormal return } \\
\text { t-statistic }\end{array}$ & $\begin{array}{c}-0.00970 \\
(-1.25)\end{array}$ & $\begin{array}{l}0.0290^{* * *} \\
(2.94)\end{array}$ & $\begin{array}{c}0.00407 \\
(0.51)\end{array}$ & $\begin{array}{r}-0.0117 \\
(-1.44)\end{array}$ & $\begin{array}{l}0.0305^{* * *} \\
\quad(3.00)\end{array}$ & $\begin{array}{c}0.00320 \\
(0.37)\end{array}$ \\
\hline \multicolumn{7}{|l|}{ Within firms: } \\
\hline $\begin{array}{l}\text { Abnormal return } \\
\text { t-statistic }\end{array}$ & $\begin{array}{c}-0.00970 \\
(-1.22) \\
\end{array}$ & $\begin{array}{c}0.0290^{* * *} \\
(3.08) \\
\end{array}$ & $\begin{array}{c}0.00407 \\
(0.50) \\
\end{array}$ & $\begin{array}{r}-0.0117 \\
(-1.41) \\
\end{array}$ & $\begin{array}{c}0.0305^{* * *} \\
(3.18) \\
\end{array}$ & $\begin{array}{c}0.00320 \\
(0.37) \\
\end{array}$ \\
\hline \multicolumn{7}{|c|}{ Panel C: Only 8-K filings \& non-penny stocks } \\
\hline \multicolumn{7}{|l|}{ Across firms: } \\
\hline $\begin{array}{l}\text { Abnormal return } \\
\text { t-statistic }\end{array}$ & $\begin{array}{c}-0.0109 \\
(-1.35)\end{array}$ & $\begin{array}{c}0.0281^{* * *} \\
(2.68)\end{array}$ & $\begin{array}{c}0.00460 \\
(0.35)\end{array}$ & $\begin{array}{c}-0.0132 \\
(-1.47)\end{array}$ & $\begin{array}{l}0.0300^{* * *} \\
(2.68)\end{array}$ & $\begin{array}{l}0.00386 \\
(0.28)\end{array}$ \\
\hline \multicolumn{7}{|l|}{ Within firms: } \\
\hline $\begin{array}{l}\text { Abnormal return } \\
\text { t-statistic }\end{array}$ & $\begin{array}{c}-0.0109 \\
(-1.28)\end{array}$ & $\begin{array}{c}0.0281^{* * *} \\
(2.73)\end{array}$ & $\begin{array}{c}0.00460 \\
(0.36)\end{array}$ & $\begin{array}{c}-0.0132 \\
(-1.43)\end{array}$ & $\begin{array}{l}0.0300^{* * *} \\
(2.71)\end{array}$ & $\begin{array}{c}0.00386 \\
(0.29)\end{array}$ \\
\hline
\end{tabular}




\section{Table XI \\ Public PPP borrowers by PPP round}

Columns (1) to (3) report the mean, median, and standard deviation of several financial characteristics of firms that obtained PPP loans in PPP Round 1. Columns (4) to (6) report the same statistics for firms that obtained PPP loans in PPP Round 2. Column (7) reports the number of observations and Column (8) reports p-values from a Wilcoxon rank sum test comparing early borrowers with late borrowers. In the case of discrete variables, the statistics are proportions and the p-values are for tests of the difference in proportions. Continuous variables are winsorized at the $1^{\text {st }}$ and the $99^{\text {th }}$ percentiles.

\begin{tabular}{|c|c|c|c|c|c|c|c|c|}
\hline & \multicolumn{3}{|c|}{$\begin{array}{l}\text { Early PPP borrowers } \\
(\mathrm{N}=431)\end{array}$} & \multicolumn{3}{|c|}{$\begin{array}{l}\text { Late PPP borrowers } \\
\qquad(\mathrm{N}=231)\end{array}$} & \multicolumn{2}{|c|}{$\begin{array}{l}\text { Difference } \\
\text { tests }\end{array}$} \\
\hline & Mean & Median & $\mathrm{SD}$ & Mean & Median & $\mathrm{SD}$ & $\mathrm{N}$ & $\mathrm{p}$-value \\
\hline & (1) & $(2)$ & (3) & (4) & (5) & (6) & $(7)$ & (8) \\
\hline \multicolumn{9}{|c|}{ Panel A: Firm size } \\
\hline PPP Loan Amount (\$ million) & 2.566 & 1.384 & 3.025 & 1.912 & 0.700 & 3.095 & 662 & 0.000 \\
\hline Book Value of Assets (\$ million) & 88.9 & 38.9 & 135.3 & 74.5 & 23.9 & 167.3 & 543 & 0.000 \\
\hline Market Cap (\$ million) & 99.4 & 40.1 & 176.4 & 76.5 & 23.8 & 161.7 & 539 & 0.000 \\
\hline Sales (\$ million) & 73.7 & 26.5 & 132.2 & 82.2 & 12.0 & 217.6 & 543 & 0.002 \\
\hline \# Employees ('000) & 0.252 & 0.105 & 0.382 & 0.223 & 0.059 & 0.373 & 536 & 0.003 \\
\hline \multicolumn{9}{|c|}{ Panel B: Other financial characteristics } \\
\hline Firm Age (years) & 16.014 & 13.000 & 12.693 & 15.685 & 12.000 & 12.876 & 543 & 0.769 \\
\hline Book Equity $<0(1 / 0)$ & $18.0 \%$ & - & - & $31.5 \%$ & - & - & 542 & 0.000 \\
\hline Tobin's Q & 1.777 & 1.200 & 2.224 & 1.465 & 0.981 & 2.129 & 543 & 0.001 \\
\hline Sales Growth & 0.611 & 0.032 & 3.315 & 0.443 & 0.017 & 2.408 & 488 & 0.819 \\
\hline Dividend Payer $(1 / 0)$ & $14.9 \%$ & - & - & $12.2 \%$ & - & - & 543 & 0.021 \\
\hline Current Ratio & 2.535 & 1.780 & 2.807 & 2.437 & 1.359 & 4.233 & 541 & 0.002 \\
\hline Cash/Non-Cash Assets & 1.035 & 0.232 & 3.448 & 1.060 & 0.162 & 2.756 & 543 & 0.415 \\
\hline Free Cash Flow/Assets & 0.149 & 0.033 & 0.945 & 0.416 & 0.052 & 2.431 & 457 & 0.201 \\
\hline \multicolumn{9}{|c|}{ Panel C: Financial constraints } \\
\hline Has Credit Rating $(1 / 0)$ & $1.9 \%$ & - & - & $2.2 \%$ & - & - & 662 & 0.067 \\
\hline WW Index $\geq$ p75 $(1 / 0)$ & $72.8 \%$ & - & - & $69.6 \%$ & - & - & 382 & 0.682 \\
\hline SA Index $\geq$ p75 (1/0) & $76.6 \%$ & - & - & $79.6 \%$ & - & - & 491 & 0.688 \\
\hline \multicolumn{9}{|c|}{ Panel D: Leverage and distress } \\
\hline Zero Debt $(1 / 0)$ & $8.8 \%$ & - & - & $11.0 \%$ & - & - & 543 & 0.020 \\
\hline Market Leverage & 0.234 & 0.165 & 0.225 & 0.306 & 0.196 & 0.299 & 488 & 0.070 \\
\hline Interest Coverage $<1.5(1 / 0)$ & $77.9 \%$ & - & - & $82.6 \%$ & - & - & 424 & 0.565 \\
\hline Altman Z-score $<1.81(1 / 0)$ & $68.8 \%$ & - & - & $72.4 \%$ & - & - & 464 & 0.607 \\
\hline Distance-to-Default & 2.698 & 2.359 & 2.026 & 2.446 & 1.794 & 2.138 & 384 & 0.052 \\
\hline Penny Stock $(1 / 0)$ & $72.8 \%$ & - & - & $83.2 \%$ & - & - & 539 & 0.153 \\
\hline \multicolumn{9}{|c|}{ Panel E: Stock returns } \\
\hline Covid Period Return & -0.325 & -0.394 & 0.393 & -0.328 & -0.416 & 0.393 & 617 & 0.698 \\
\hline Stimulus Day Return & 0.056 & 0.044 & 0.111 & 0.053 & 0.030 & 0.120 & 621 & 0.294 \\
\hline
\end{tabular}




\section{Table XII}

\section{Propensity to borrow early under PPP}

This table reports the results from a linear probability (OLS) model where the dependent variable is an indicator for public company receiving a PPP loan before April 17, 2020 when the PPP funds ran out and independent variables are company characteristics. Continuous variables are winsorized at the $1^{\text {st }}$ and the $99^{\text {th }}$ percentiles. Standard errors are clustered at the industry level, defined as 2-digit NAICS, where we combine industries with few PPP-eligible companies into one bucket. ${ }^{* *}, * *$, and $*$ denote statistical significance at the $1 \%, 5 \%$, and $10 \%$ levels, respectively. $t$-statistics are presented in parentheses.

\begin{tabular}{|c|c|c|c|}
\hline & \multicolumn{3}{|c|}{ Dependent variable $=$ Early PPP Borrower $(1 / 0)$} \\
\hline & (1) & $(2)$ & (3) \\
\hline Log (Assets) & $\begin{array}{c}0.0330 * * \\
(2.33)\end{array}$ & $\begin{array}{c}0.0319^{* *} \\
(2.20)\end{array}$ & $\begin{array}{c}0.0378^{* *} \\
(2.37)\end{array}$ \\
\hline Log (Age) & $\begin{array}{c}-0.00187 \\
(-0.05)\end{array}$ & $\begin{array}{c}0.00102 \\
(0.03)\end{array}$ & $\begin{array}{c}0.00357 \\
(0.11)\end{array}$ \\
\hline Book Equity <0 (1/0) & $\begin{array}{c}-0.112^{* *} \\
(-2.50)\end{array}$ & $\begin{array}{c}-0.114^{* *} \\
(-2.58)\end{array}$ & $\begin{array}{c}-0.105^{* *} \\
(-2.38)\end{array}$ \\
\hline Tobin's Q & $\begin{array}{c}0.00134 \\
(0.08)\end{array}$ & $\begin{array}{c}0.00104 \\
(0.06)\end{array}$ & $\begin{array}{c}0.00546 \\
(0.31)\end{array}$ \\
\hline Current Ratio & $\begin{array}{c}-0.00487 \\
(-0.56)\end{array}$ & $\begin{array}{c}-0.00466 \\
(-0.53)\end{array}$ & $\begin{array}{c}-0.00467 \\
(-0.52)\end{array}$ \\
\hline Cash/Non-Cash Assets & $\begin{array}{c}0.00247 \\
(0.75)\end{array}$ & $\begin{array}{c}0.00177 \\
(0.52)\end{array}$ & $\begin{array}{c}0.00237 \\
(0.72)\end{array}$ \\
\hline Penny Stock $(1 / 0)$ & $\begin{array}{r}-0.0687 \\
(-0.99)\end{array}$ & $\begin{array}{r}-0.0727 \\
(-1.03)\end{array}$ & $\begin{array}{l}-0.126 \\
(-1.60)\end{array}$ \\
\hline Covid Industry $(1 / 0)$ & & $\begin{array}{c}0.0198 \\
(0.25)\end{array}$ & $\begin{array}{c}0.0332 \\
(0.40)\end{array}$ \\
\hline Machinery Industry $(1 / 0)$ & & $\begin{array}{c}0.0210 \\
(0.23)\end{array}$ & $\begin{array}{l}0.0324 \\
(0.37)\end{array}$ \\
\hline Health Industry $(1 / 0)$ & & $\begin{array}{c}0.0146 \\
(0.41)\end{array}$ & $\begin{array}{c}0.00537 \\
(0.15)\end{array}$ \\
\hline High-Tech Industry $(1 / 0)$ & & $\begin{array}{c}-0.0345 \\
(-0.92)\end{array}$ & $\begin{array}{c}-0.0309 \\
(-0.80)\end{array}$ \\
\hline Covid Period Return & & & $\begin{array}{c}0.00513 \\
(0.04)\end{array}$ \\
\hline Covid Period Return $\times$ Penny Stock $(1 / 0)$ & & & $\begin{array}{c}0.0209 \\
(0.16)\end{array}$ \\
\hline Stimulus Day Return & & & $\begin{array}{l}-0.726 \\
(-1.64)\end{array}$ \\
\hline Stimulus Day Return × Penny Stock $(1 / 0)$ & & & $\begin{array}{l}0.623 \\
(1.50)\end{array}$ \\
\hline \# obs. & 521 & 521 & 513 \\
\hline Adjusted $\mathrm{R}^{2}$ & 0.0298 & 0.0236 & 0.0244 \\
\hline
\end{tabular}




\section{Table XIII}

\section{Early versus late PPP borrowers and big-10 banks}

This table compares the size of early versus late PPP borrowers that obtained a PPP loan through one of big-10 banks (Big-10 Bank) versus other banks (Smaller Bank). The size variable is Book Value of Assets in Panel A and PPP Loan Amount in Panel B. We classify the following banks as big-10 banks: JPMorgan Chase Bank, Wells Fargo Bank, Bank of America, Citibank, U.S. Bank, Truist Bank, PNC Bank, Bank of New York, State Street Corporation, and TD Bank. Columns (1) to (2) report the mean of the size variable for firms that obtained PPP loans in PPP Round 1 (i.e., early PPP borrowers) and PPP Round 2 (i.e., late PPP borrowers), respectively. Column (3) reports the number of observations and Column (4) reports p-values from a Wilcoxon rank sum test comparing early borrowers with late borrowers. Continuous variables are winsorized at the $1^{\text {st }}$ and the $99^{\text {th }}$ percentiles.

\begin{tabular}{|c|c|c|c|c|}
\hline & \multicolumn{2}{|c|}{ Mean Size Variable } & \multicolumn{2}{|c|}{ Difference tests } \\
\hline & Early PPP borrowers & Late PPP borrowers & $\mathrm{N}$ & p-value \\
\hline & $(1)$ & $(2)$ & $(3)$ & $(4)$ \\
\hline \multicolumn{5}{|c|}{ Panel B: Size Variable = Book Value of Assets ( $\$$ million $)$} \\
\hline Big-10 Banks & 144.227 & 62.444 & 151 & 0.000 \\
\hline Smaller Banks & 76.042 & 94.298 & 357 & 0.485 \\
\hline \multicolumn{5}{|c|}{ Panel A: Size Variable = PPP Loan Amount $(\$$ million $)$} \\
\hline Big-10 Banks & 3.389 & 1.794 & 187 & 0.000 \\
\hline Smaller Banks & 2.538 & 2.248 & 470 & 0.004 \\
\hline
\end{tabular}




\section{Table XIV \\ Early PPP borrowers and lender effects}

This table reports the results from a multinomial logit model for public PPP recipients where the dependent variable is a categorical variable for the intersection between a bank type (big-10 bank versus smaller bank) and borrower type (early versus late PPP borrower). The independent variable is the PPP loan size (Panel A) or firm size (Panel B). The dependent variable Bank Type-Borrower Type Category $(Y)$ takes the value of 3 for big-10 bank and early PPP borrower, 2 for big-10 bank and late PPP borrower, 1 for smaller bank and early PPP borrower, and 0 for smaller bank and late PPP borrower. We classify the following banks as big-10 banks: JPMorgan Chase Bank, Wells Fargo Bank, Bank of America, Citibank, U.S. Bank, Truist Bank, PNC Bank, Bank of New York, State Street Corporation, and TD Bank. An early borrower is a public company receiving a PPP loan before April 17, 2020. Continuous variables are winsorized at the $1^{\text {st }}$ and the $99^{\text {th }}$ percentiles. Standard errors are clustered at the industry level, defined as 2-digit NAICS, where we combine industries with few PPP-eligible companies into one bucket. ***, **, and ${ }^{*}$ denote statistical significance at the $1 \%, 5 \%$, and $10 \%$ levels, respectively. $z$-statistics are presented in parentheses.

\begin{tabular}{|c|c|c|c|}
\hline & \multicolumn{3}{|c|}{ Dependent variable $=$ Bank Type-Borrower Type Category $(\mathrm{Y})$} \\
\hline & Predictor & Coefficient & z-statistic \\
\hline & $(1)$ & $(2)$ & $(3)$ \\
\hline \multicolumn{4}{|c|}{ Panel A: PPP loan size } \\
\hline $\begin{array}{l}\mathrm{Y}=3: \text { Big-10 Bank-Early PPP Borrower } \\
\mathrm{Y}=2: \text { Big-10 Bank-Late PPP Borrower } \\
\mathrm{Y}=1: \text { Smaller Bank-Early PPP Borrower } \\
\mathrm{Y}=0: \text { Smaller Bank-Late PPP Borrower }\end{array}$ & $\begin{array}{l}\text { Log (PPP Loan Amount) } \\
\text { Log (PPP Loan Amount) } \\
\text { [Base outcome] } \\
\text { Log (PPP Loan Amount) }\end{array}$ & $\begin{array}{c}0.272^{* * *} \\
-0.306^{* * *} \\
-0.115\end{array}$ & $\begin{array}{c}(2.86) \\
(-4.52) \\
- \\
(-0.96)\end{array}$ \\
\hline $\begin{array}{l}\text { \# obs. } \\
\text { Pseudo- } R^{2} \\
\text { Log-likelihood }\end{array}$ & $\begin{array}{l}508 \\
0.0172 \\
-607.1\end{array}$ & & \\
\hline \multicolumn{4}{|c|}{ Panel B: Firm size } \\
\hline $\begin{array}{l}\mathrm{Y}=3: \text { Big-10 Bank-Early PPP Borrower } \\
\mathrm{Y}=2: \text { Big-10 Bank-Late PPP Borrower } \\
\mathrm{Y}=1: \text { Smaller Bank-Early PPP Borrower } \\
\mathrm{Y}=0: \text { Smaller Bank-Late PPP Borrower }\end{array}$ & $\begin{array}{l}\text { Log (Assets) } \\
\text { Log (Assets) } \\
\text { [Base outcome] } \\
\text { Log (Assets) }\end{array}$ & $\begin{array}{c}0.229^{* * *} \\
-0.217^{* * *} \\
- \\
-0.0888\end{array}$ & $\begin{array}{c}(3.57) \\
(-4.36) \\
- \\
(-1.21)\end{array}$ \\
\hline $\begin{array}{l}\text { \# obs. } \\
\text { Pseudo- } R^{2} \\
\text { Log-likelihood }\end{array}$ & $\begin{array}{l}508 \\
0.0159 \\
-607.9\end{array}$ & & \\
\hline
\end{tabular}




\section{Table XV \\ Early PPP borrowers and lender effects: SBA PPP data}

This table reports the results from a multinomial logit model based on SBA PPP data where the dependent variable is a categorical variable for the intersection between a bank type (big-10 bank versus smaller bank) and borrower type (early versus late PPP borrower). The independent variables are the PPP loan size bin dummies (as binned by SBA). The dependent variable Bank Type-Borrower Type Category $(Y)$ takes the value of 3 for big-10 bank and early PPP borrower, 2 for big-10 bank and late PPP borrower, 1 for smaller bank and early PPP borrower, and 0 for smaller bank and late PPP borrower. We classify the following banks as big-10 banks: JPMorgan Chase Bank, Wells Fargo Bank, Bank of America, Citibank, U.S. Bank, Truist Bank, PNC Bank, Bank of New York, State Street Corporation, and TD Bank. An early borrower is a public company receiving a PPP loan before April 17, 2020. Continuous variables are winsorized at the $1^{\text {st }}$ and the $99^{\text {th }}$ percentiles. Standard errors are clustered at the industry level, defined as 2-digit NAICS, where we combine industries with few PPP-eligible companies into one bucket. ***, **, and * denote statistical significance at the 1\%,5\%, and $10 \%$ levels, respectively. $z$-statistics are presented in parentheses.

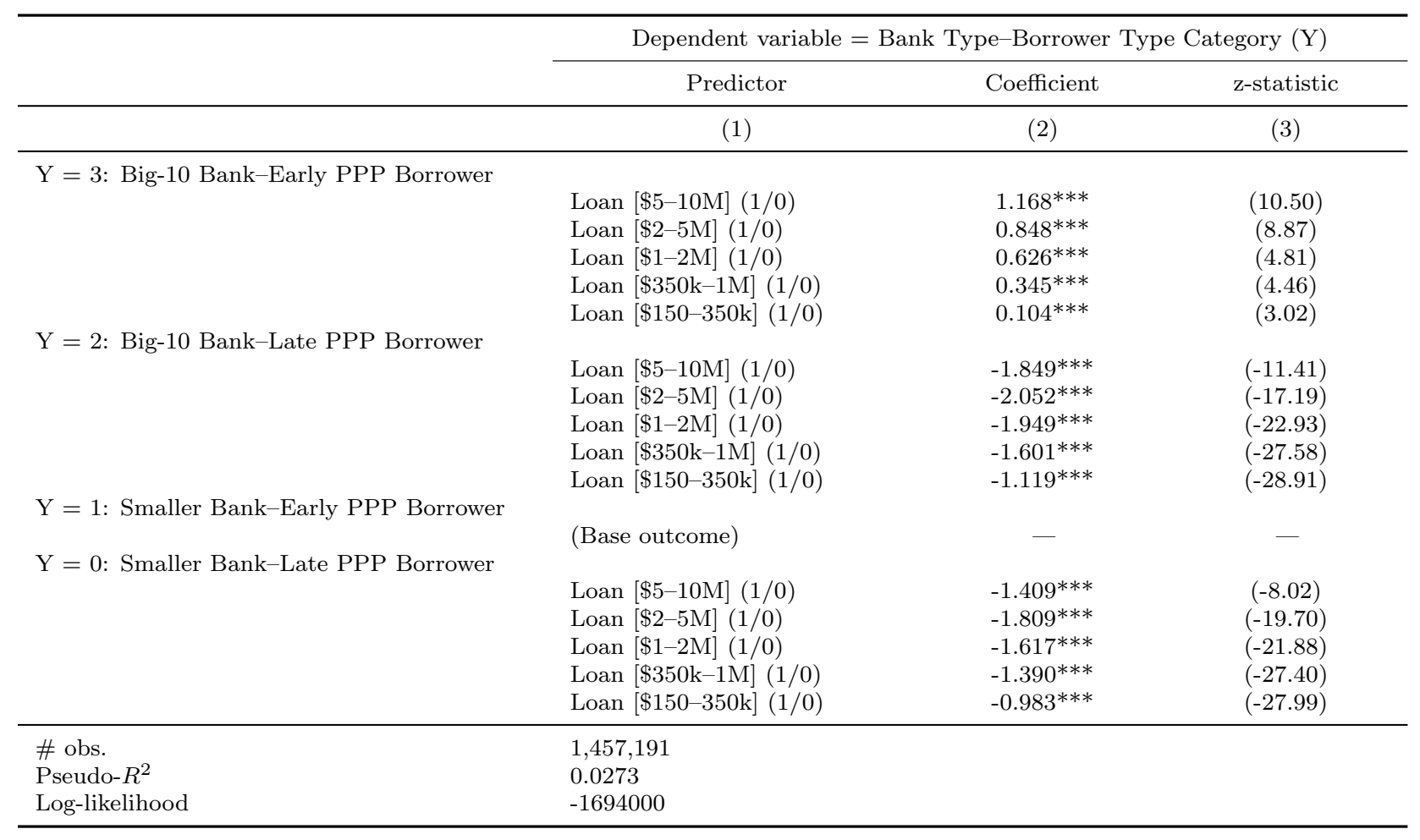




\section{Appendix A. Definitions of Variables}

\begin{tabular}{|c|c|c|c|}
\hline Variable & Definition & Source & Formula \\
\hline \multicolumn{4}{|l|}{ PPP borrowing } \\
\hline PPP Borrower (1/0) & $\begin{array}{l}\text { Dummy for PPP borrower vs. public } \\
\text { PPP-eligible non-borrower }\end{array}$ & EDGAR & $=1$ if borrower, $0 \mathrm{o} / \mathrm{w}$ \\
\hline PPP Loan Returner $(1 / 0)$ & $\begin{array}{l}\text { Dummy for PPP loan returner versus PPP } \\
\text { loan retainer }\end{array}$ & EDGAR & $=1$ if loan returned, $0 \mathrm{o} / \mathrm{w}$ \\
\hline Early PPP Borrower (1/0) & $\begin{array}{l}\text { Dummy for early PPP borrower vs. late } \\
\text { borrower, defined based on SBA approval } \\
\text { date, loan grant date, or contract date (in } \\
\text { that order) }\end{array}$ & $\begin{array}{l}\text { EDGAR, } \\
\text { SBA }\end{array}$ & $\begin{array}{l}=1 \text { if approved or borrowed } \\
\text { before April } 27,2020,0 \mathrm{o} / \mathrm{w}\end{array}$ \\
\hline PPP Loan Amount (\$ million) & $\begin{array}{l}\text { Aggregate PPP loan amount per EDGAR } \\
\text { filer, measured in } \$ \text { million }\end{array}$ & EDGAR & $=$ ppp_size \\
\hline Above $\$ 2 \mathrm{M}(1 / 0)$ & $\begin{array}{l}\text { Dummy for PPP loan size of } \$ 2 \text { million or } \\
\text { above }\end{array}$ & EDGAR & $=($ ppp_size $\geq 2)$ \\
\hline Distance (\$ million) & $\begin{array}{l}\text { Difference between PPP loan amount and } \$ 2 \\
\text { million }\end{array}$ & EDGAR & $=$ ppp_size- 2 \\
\hline Loan $[\dagger](1 / 0)$ & $\begin{array}{l}\text { PPP loan size bin, where } \dagger \text { defines the bin; } \\
\text { loan amounts } \geq 150,000 \text { are binned by SBA } \\
\text { and loans of }<150,000 \text { grouped into a } \\
\text { separate bin }\end{array}$ & $\begin{array}{l}\text { SBA PPP } \\
\text { data (Aug) }\end{array}$ & $=$ loanrange \\
\hline Big-10 Bank (1/0) & $\begin{array}{l}\text { Dummy for PPP lender being JPMorgan } \\
\text { Chase Bank, Wells Fargo Bank, Bank of } \\
\text { America, Citibank, U.S. Bank, Truist Bank, } \\
\text { PNC Bank, Bank of New York, State Street } \\
\text { Corporation, or TD Bank }\end{array}$ & Call reports & $=1$ if big_bank $=1,0 \mathrm{o} / \mathrm{w}$ \\
\hline $\begin{array}{l}\text { Bank Type-Borrower Type } \\
\text { Category }\end{array}$ & $\begin{array}{l}\text { Categorical variable for the intersection } \\
\text { between a bank type (big- } 10 \text { bank versus } \\
\text { smaller bank) and borrower type (early } \\
\text { versus late PPP borrower) }\end{array}$ & $\begin{array}{l}\text { EDGAR, } \\
\text { Call reports }\end{array}$ & $\begin{array}{l}=3 \text { if big_bank }=1 \& \text { early }=1 ; \\
2 \text { if big_bank }=1 \& \text { early }=0 ; 1 \text { if } \\
\text { big_bank }=0 \& \text { early }=1 ; 0 \text { if } \\
\text { big_bank }=0 \& \text { early }=0\end{array}$ \\
\hline \multicolumn{4}{|l|}{ Firm size } \\
\hline Book Value of Assets ( $\$$ million) & Assets, measured in $\$$ million & Compustat & $=a t$ \\
\hline Log (Assets) & Ln of Assets & Compustat & $=\log (\mathrm{at})$ \\
\hline Market Cap (\$ million) & Market Capitalization, measured in $\$$ million & Compustat & $=$ prcc $_{-} f^{*} \operatorname{csho}$ \\
\hline Sales (\$ million) & Sales, measured in $\$$ million & Compustat & $=$ sale \\
\hline \# Employees ('000) & Employees, measured in thousand & Compustat & $=\mathrm{emp}$, set to 2018 if $\mathrm{N} / \mathrm{A}$ \\
\hline \multicolumn{4}{|l|}{ Other financial characteristics } \\
\hline Firm Age (years) & Years since IPO, capped at 37 years & Compustat & $\begin{array}{l}=\text { fyear-min }(\text { fyear }) \text { if prcc } f !=., \\
0 \text { if missing }\end{array}$ \\
\hline Log (Age) & Ln of Years since IPO, capped at 37 years & Compustat & $\begin{array}{l}=\log (\text { fyear-min }(\text { fyear })) \text { if } \\
\text { prcc_f } !=., 0 \text { if missing }\end{array}$ \\
\hline Book Equity <0 & $\begin{array}{l}\text { Dummy for negative Book Equity defined as } \\
\text { in Fama-French: BE = book value of } \\
\text { stockholders' equity, plus balance sheet } \\
\text { deferred taxes and investment tax credit (if } \\
\text { available), minus the book value of preferred } \\
\text { stock }\end{array}$ & Compustat & $\begin{array}{l}=(\text { seq OR ceq }+ \text { pstk OR at-lt, } \\
\text { in that order })+(\text { txditc OR } \\
\text { txdb+itcb, where each is set to } \\
0 \text { if missing OR } 0, \text { in that } \\
\text { order })+(\text { pstkrv OR pstkl OR } \\
\text { pstk, in that order })\end{array}$ \\
\hline Tobin's Q & Market Value of Assets/Assets & Compustat & $\begin{array}{l}=\left(\text { at }+ \text { prcc_f }^{*}{ }^{*} \text { csho-ceq }\right) / \text { at, set } \\
\text { to } 0 \text { if } \text { ceq }<0 \text { or if missing }\end{array}$ \\
\hline Sales Growth & Year-on-year sales growth & Compustat & $=\left(\right.$ sale-sale $\left.\left[\_n-1\right]\right) /$ sale $\left[\_n-1\right]$ \\
\hline Dividend Payer (1/0) & Dummy for dividend payer & Compustat & $=(\mathrm{dv}>0)$ if $\mathrm{dv} !=$ \\
\hline Current Ratio & Current Assets/Current Liabilities & Compustat & $=\mathrm{act} / \mathrm{lct}$ \\
\hline Cash/Non-Cash Assets & Cash/(Assets-Cash) & Compustat & $\begin{array}{l}=\text { che } /(\text { at-che }), \text { where at is in } \\
\text { thousands }\end{array}$ \\
\hline Free Cash Flow/Assets & $\begin{array}{l}\text { (Operating Cash Flow - Extraordinary Items } \\
\text { + Interest Paid - Interest Expense*((Pretax } \\
\text { Income - Net Income)/Pretax Income) - } \\
\text { CapEx)/Assets }\end{array}$ & Compustat & $\begin{array}{l}=(\text { oancf-xidoc }+ \text { intpn-xint } *((p i- \\
\text { ni }) / \text { pi })- \text { capx }) / \text { at }\end{array}$ \\
\hline \multicolumn{4}{|l|}{ Financial constraints } \\
\hline Has Credit Rating (1/0) & $\begin{array}{l}\text { Dummy for company having a long-term } \mathrm{S} \& \mathrm{P} \\
\text { credit rating or a Mergent rating for an issue } \\
\text { with maturity of at least three years }\end{array}$ & $\begin{array}{l}\text { S\&P, } \\
\text { Mergent }\end{array}$ & $=1$ if rated, $0 \mathrm{o} / \mathrm{w}$ \\
\hline
\end{tabular}




\begin{tabular}{|c|c|c|c|}
\hline WW Index $\geq$ p75 (1/0) & $\begin{array}{l}\text { Dummy for WW Index in } 4 \text { th (upper) } \\
\text { quartile, where WW (Whited and Wu) Index } \\
\text { is calculated as }-0.737^{*} \text { Ln of } \\
\text { Min(Assets, } 4500)+0.043^{*} \text { Squared Ln of } \\
\text { Min(Assets, } 4500)-0.040^{*} \text { Min(Years since } \\
\text { IPO,37) } \\
\text { Dummy for SA Index in } 4 \text { th (upper) quartile, } \\
\text { where SA (Hadlock and Pierce) Index is } \\
\left.\text { calculated as }-0.737^{*} \text { Ln of Min(Assets, } 4500\right) \\
\left.+0.043^{*} \text { Squared Ln of Min(Assets, } 4500\right)- \\
0.040^{*} \text { Min(Years since IPO,37) }\end{array}$ & Compustat & $\begin{array}{l}=(\text { WW_quart }==4) \text { if } \\
\text { WW_quart! }=., \text { using xtile, } \\
\text { where } \\
\text { WW=-0.737* } \log (\min (\text { at }, 4500)) \\
+0.043^{*}(\log (\min (\text { at }, 4500)))^{2} \\
-0.040^{*} \min (\text { age, } 37) \\
=(\text { SA_quart==4 }) \text { if } \\
\text { SA_quart! }=., \text { using xtile, where } \\
\text { SA=-0.737* } \log (\min (\text { at, }, 4500)) \\
+0.043^{*}(\log (\min (\text { at }, 4500)))^{2} \\
-0.040^{*} \min (\text { age, } 37)\end{array}$ \\
\hline Variable & Definition & & \\
\hline \multicolumn{4}{|l|}{ Leverage and distress } \\
\hline Zero Debt $(1 / 0)$ & Dummy for zero debt & Compustat & $\begin{array}{l}=1 \text { if } \mathrm{dlc}+\mathrm{dltt}=0 \text { or }(\mathrm{dltt}=. \& \\
\mathrm{dlc}=0), 0 \mathrm{o} / \mathrm{w}\end{array}$ \\
\hline Market Leverage & $\begin{array}{l}\text { (Short-Term Debt + Long-Term Debt)/(Debt } \\
+ \text { Market Cap) }\end{array}$ & Compustat & $\begin{array}{l}=(\text { dlc }+ \text { dltt }) / \\
\left(\text { dlc }+ \text { dltt }+ \text { prcc_f } f^{*} \operatorname{csho}\right)\end{array}$ \\
\hline Interest Coverage $<1.5(1 / 0)$ & $\begin{array}{l}\text { Dummy for } 1+\text { Pretax Income/Interest } \\
\text { Expense }<1.5\end{array}$ & Compustat & $\begin{array}{l}=((1+\text { pi } / \text { xint })<1.5) \text { if } \\
(1+\text { pi } / \text { xint }) !=\end{array}$ \\
\hline Altman Z-score $<1.81(1 / 0)$ & $\begin{array}{l}\text { Dummy for Altman Z-score }<1.81 \text {, wehere } \\
\text { Z-score is calculated as } 1.2^{*} \text { Working } \\
\text { Capital/Assets }+1.4^{*} \text { Retained } \\
\text { Earnings/Assets }+3.3^{*} \text { EBIT/Assets }+ \\
0.6^{*} \text { Market Cap/Liabilities }+ \\
0.999^{*} \text { Sales/Assets }\end{array}$ & Compustat & $\begin{array}{l}=1 \text { if } Z \text {-score }<1.81,0 \mathrm{o} / \mathrm{w} \\
\text { where } \mathrm{Z} \text {-score }= \\
1.2^{*}(\text { act-lct }) / \mathrm{at}+1.4^{*} \mathrm{re} / \mathrm{at} \\
+3.3^{*}(\mathrm{pi}+\mathrm{xint}+\mathrm{dp}- \\
\mathrm{dp}) / \mathrm{at}+.6^{*} \text { prcc_f* } \mathrm{csho} / \mathrm{lt} \\
+.999^{*} \text { sale/at }\end{array}$ \\
\hline Distance-to-Default & $\begin{array}{l}\text { Distance-to-default from NUS RMI Credit } \\
\text { Research Initiative }\end{array}$ & NUS RMI & $=\mathrm{dtd}$ \\
\hline Penny Stock $(1 / 0)$ & $\begin{array}{l}\text { Dummy for company's stock price below } \$ 5 \\
\text { based on (1) closing stock price as of fiscal } \\
\text { year-end for cross-sectional tests or }(2) \\
\text { average stock price in December } 2019 \text { for } \\
\text { event study analysis }\end{array}$ & Compustat & 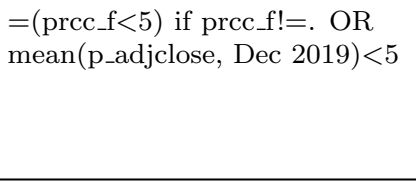 \\
\hline \multicolumn{4}{|l|}{ Industry composition } \\
\hline Covid Industry $(1 / 0)$ & Dummy for Covid-19 Affected Industry & Compustat & $\begin{array}{l}=1 \text { if sic corresponds to } \\
\text { Covid-19 industry, } 0 \mathrm{o} / \mathrm{w}\end{array}$ \\
\hline Machinery Industry $(1 / 0)$ & Dummy for Machinery Industry & Compustat & $\begin{array}{l}=1 \text { if sic corresponds to } \\
\mathrm{FF} 49==21,0 \mathrm{o} / \mathrm{w}\end{array}$ \\
\hline Health Industry $(1 / 0)$ & $\begin{array}{l}\text { Dummy for Health, Pharma, and Biotech } \\
\text { Industry }\end{array}$ & Compustat & $\begin{array}{l}=1 \text { if sic corresponds to } \\
\text { FF } 49==11,12,13,0 \text { o } / \mathrm{w}\end{array}$ \\
\hline High-Tech industry $(1 / 0)$ & $\begin{array}{l}\text { Dummy for Business Equipment - } \\
\text { Computers, Software, and Electronic } \\
\text { Equipment Industry }\end{array}$ & Compustat & $\begin{array}{l}=1 \text { if sic corresponds to } \\
\text { FF } 49==35,36,37,0 \text { o/w }\end{array}$ \\
\hline \multicolumn{4}{|l|}{ Returns and event study variables } \\
\hline Buy-and-Hold Abnormal Return & $\begin{array}{l}\text { Cumulative return on the stock over the S\&P } \\
500 \text { return from January } 1,2020 \text { to August } \\
15,2020 \text {, adjusted for stock splits and } \\
\text { dividends }\end{array}$ & $\begin{array}{l}\text { Yahoo! } \\
\text { Finance }\end{array}$ & $\begin{array}{l}=\text { cumulative (R_adjclose }-\mathrm{S} \& \mathrm{P} \\
500 \text { R_adjclose) }\end{array}$ \\
\hline Covid Period Return & $\begin{array}{l}\text { Cumulative stock return from February } 2, \\
2020 \text { to March } 23,2020 \text {, adjusted for stock } \\
\text { splits and dividends }\end{array}$ & $\begin{array}{l}\text { Yahoo! } \\
\text { Finance }\end{array}$ & $\begin{array}{l}=\text { cumulative } R_{\_} \text {adjclose, Covid } \\
\text { period }\end{array}$ \\
\hline Stimulus Day Return & $\begin{array}{l}\text { Stock return on March } 24,2020 \text {, adjusted for } \\
\text { stock splits and dividends }\end{array}$ & $\begin{array}{l}\text { Yahoo! } \\
\text { Finance }\end{array}$ & $=\mathrm{R} \_$adjclose, Mar 24, 2020 \\
\hline Abnormal Return & $\begin{array}{l}\text { Company's (1) market-adjusted return (stock } \\
\text { return minus S\&P } 500 \text { return) or (2) market } \\
\text { model return (based on S\&P 500), adjusted } \\
\text { for stock splits and dividends }\end{array}$ & $\begin{array}{l}\text { Yahoo! } \\
\text { Finance }\end{array}$ & $\begin{array}{l}=R \_ \text {adjclose }-\mathrm{S} \& \mathrm{P} 500 \\
\mathrm{R} \_ \text {adjclose OR Abnormal } \\
\text { R_adjclose }\end{array}$ \\
\hline Day $-1(1 / 0)$ & $\begin{array}{l}\text { Trading day preceding (1) PPP loan grant } \\
\text { announcement day or (2) PPP loan return } \\
\text { announcement day, as appropriate }\end{array}$ & EDGAR & $\begin{array}{l}=(\text { evday }==-1) \text { OR } \\
(\text { evday } 1==-1)\end{array}$ \\
\hline Day $0(1 / 0)$ & $\begin{array}{l}\text { Trading day of (1) PPP loan grant } \\
\text { announcement or (2) PPP loan return } \\
\text { announcement, as appropriate }\end{array}$ & EDGAR & $\begin{array}{l}=(\text { evday }==0) \text { OR } \\
(\text { evday } 1==0)\end{array}$ \\
\hline Day $+1(1 / 0)$ & $\begin{array}{l}\text { Trading day following (1) PPP loan grant } \\
\text { announcement day or (2) PPP loan return } \\
\text { announcement day, as appropriate }\end{array}$ & EDGAR & $\begin{array}{l}=(\text { evday }==1) \text { OR } \\
(\text { evday } 1==1)\end{array}$ \\
\hline
\end{tabular}




\section{Appendix B. Supplementary Results}

In this Appendix, we present several additional results on the size differences between early versus late PPP borrowers by lender type where we use a more granular definition of bank size. ${ }^{24}$ We classify PPP lenders into four bank size categories, which are at least $\$ 50$ billion in assets, $\$ 10$ billion to $\$ 50$ billion in assets, $\$ 1$ billion to $\$ 10$ billion in assets, and $<\$ 1$ billion in assets, in line with SBA's classification in PPP reports. ${ }^{25}$ We find that the disparities in firm and PPP loan size between early and late PPP clients are greater for the category of banks with largest assets (i.e., $\$ 50$ billion and more). On the other hand, community banks with less than $\$ 1$ billion in assets serve smaller clients first (significant at the $10 \%$ level). These findings corroborate our results on big-10 versus smaller banks.

Table B.1

\section{Early versus late borrowers and lender types PPP loan amount}

This table compares the size of early versus late PPP borrowers that obtained a PPP loan through banks of different size, as measured by bank total assets. The size variable is Book Value of Assets in Panel A and PPP Loan Amount in Panel B. We classify the following banks into four size categories: Banks with at least $\$ 50$ billion in assets, banks with $\$ 10$ billion to $\$ 50$ billion in assets, banks with $\$ 1$ billion to $\$ 10$ billion in assets, and banks with $<\$ 1$ billion in assets. Columns (1) to (2) report the mean of the size variable for firms that obtained PPP loans in PPP Round 1 (i.e., early PPP borrowers) and PPP Round 2 (i.e., late PPP borrowers), respectively. Column (3) reports the number of observations and Column (4) reports p-values from a Wilcoxon rank sum test comparing early borrowers with late borrowers. Continuous variables are winsorized at the $1^{s t}$ and the $99^{t h}$ percentiles.

\begin{tabular}{|c|c|c|c|c|}
\hline & \multicolumn{2}{|c|}{ Mean Size Variable } & \multicolumn{2}{|c|}{ Difference tests } \\
\hline & Early PPP borrowers & Late PPP borrowers & $\mathrm{N}$ & p-value \\
\hline & $(1)$ & $(2)$ & $(3)$ & $(4)$ \\
\hline \multicolumn{5}{|c|}{ Panel A: Size Variable = Book Value of Assets $(\$$ million $)$} \\
\hline Bank with $\$ 50 \mathrm{~B}+$ in Assets & 110.495 & 65.056 & 288 & 0.000 \\
\hline Bank with $\$ 10 \mathrm{~B}$ to $\$ 50 \mathrm{~B}$ in Assets & 85.602 & 67.727 & 95 & 0.021 \\
\hline Bank with $\$ 1 \mathrm{~B}$ to $\$ 10 \mathrm{~B}$ in Assets & 58.887 & 85.973 & 60 & 0.394 \\
\hline Bank with $<\$ 1 \mathrm{~B}$ in Assets & 58.563 & 169.433 & 65 & 0.096 \\
\hline \multicolumn{5}{|c|}{ Panel B: Size Variable = PPP Loan Amount $(\$$ million $)$} \\
\hline Banks with $\$ 50 \mathrm{~B}+$ in Assets & 3.047 & 2.051 & 360 & 0.000 \\
\hline Banks with $\$ 10 \mathrm{~B}$ to $\$ 50 \mathrm{~B}$ in Assets & 2.803 & 1.249 & 120 & 0.002 \\
\hline Banks with $\$ 1 \mathrm{~B}$ to $\$ 10 \mathrm{~B}$ in Assets & 2.213 & 2.005 & 89 & 0.075 \\
\hline Banks with $<\$ 1 \mathrm{~B}$ in Assets & 1.918 & 2.885 & 88 & 0.996 \\
\hline
\end{tabular}

\footnotetext{
${ }^{24}$ We use data sets maintained by the Federal Deposit Insurance Corporation (FDIC), Federal Financial Institutions Examination Council (FFIEC), and National Credit Union Administration (NCUA), including bank Call reports, to match lender names to RSSD IDs and obtain data on bank total assets.

${ }^{25}$ We discard the three non-bank lenders which provide five PPP loans in our sample from this analysis due to missing data on these lenders' assets.
} 

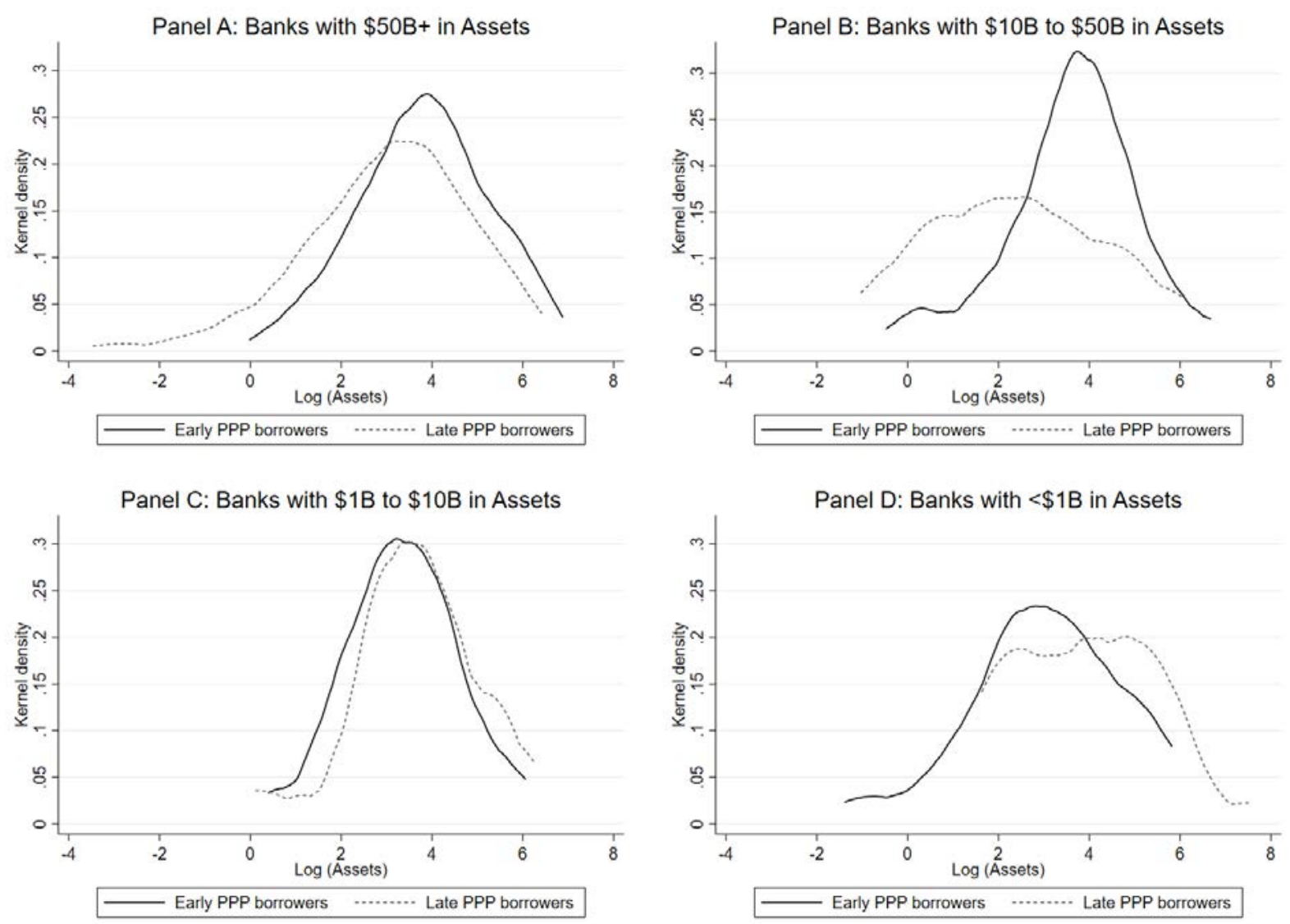

Figure B.1. PPP early borrowing and firm assets by bank size. This figure plots kernel densities of the natural logarithm of firm's assets for early versus late public PPP borrowers. Panel A reports the results for banks with $\$ 50 \mathrm{~B}+$ in assets. Panel B reports the results for banks with $\$ 10 \mathrm{~B}$ to $\$ 50 \mathrm{~B}$ in assets. Panel C reports the results for banks with $\$ 1 \mathrm{~B}$ to $\$ 10 \mathrm{~B}$ in assets. Panel D reports the results for banks with $<\$ 1 \mathrm{~B}$ in assets. Log (Assets) is winsorized at the $1^{\text {st }}$ and the $99^{t h}$ percentiles. 

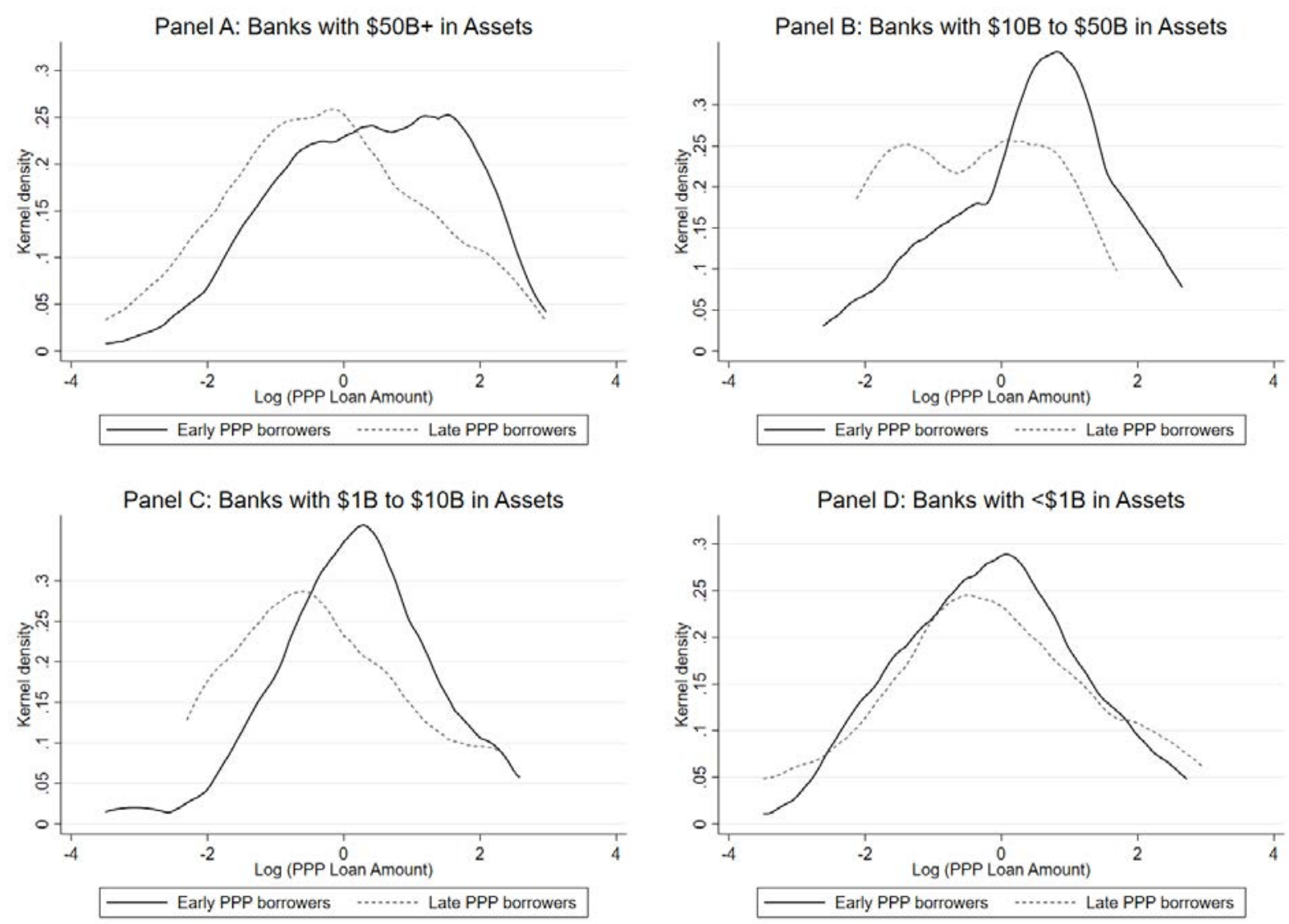

Figure B.2. PPP early borrowing and PPP loan size by bank size. This figure plots kernel densities of the natural logarithm of PPP loan amount for early versus late public PPP borrowers. Panel A reports the results for banks with $\$ 50 \mathrm{~B}+$ in assets. Panel B reports the results for banks with $\$ 10 \mathrm{~B}$ to $\$ 50 \mathrm{~B}$ in assets. Panel $\mathrm{C}$ reports the results for banks with $\$ 1 \mathrm{~B}$ to $\$ 10 \mathrm{~B}$ in assets. Panel D reports the results for banks with $<\$ 1 \mathrm{~B}$ in assets. Log (PPP Loan Amount) is winsorized at the $1^{\text {st }}$ and the $99^{\text {th }}$ percentiles. 

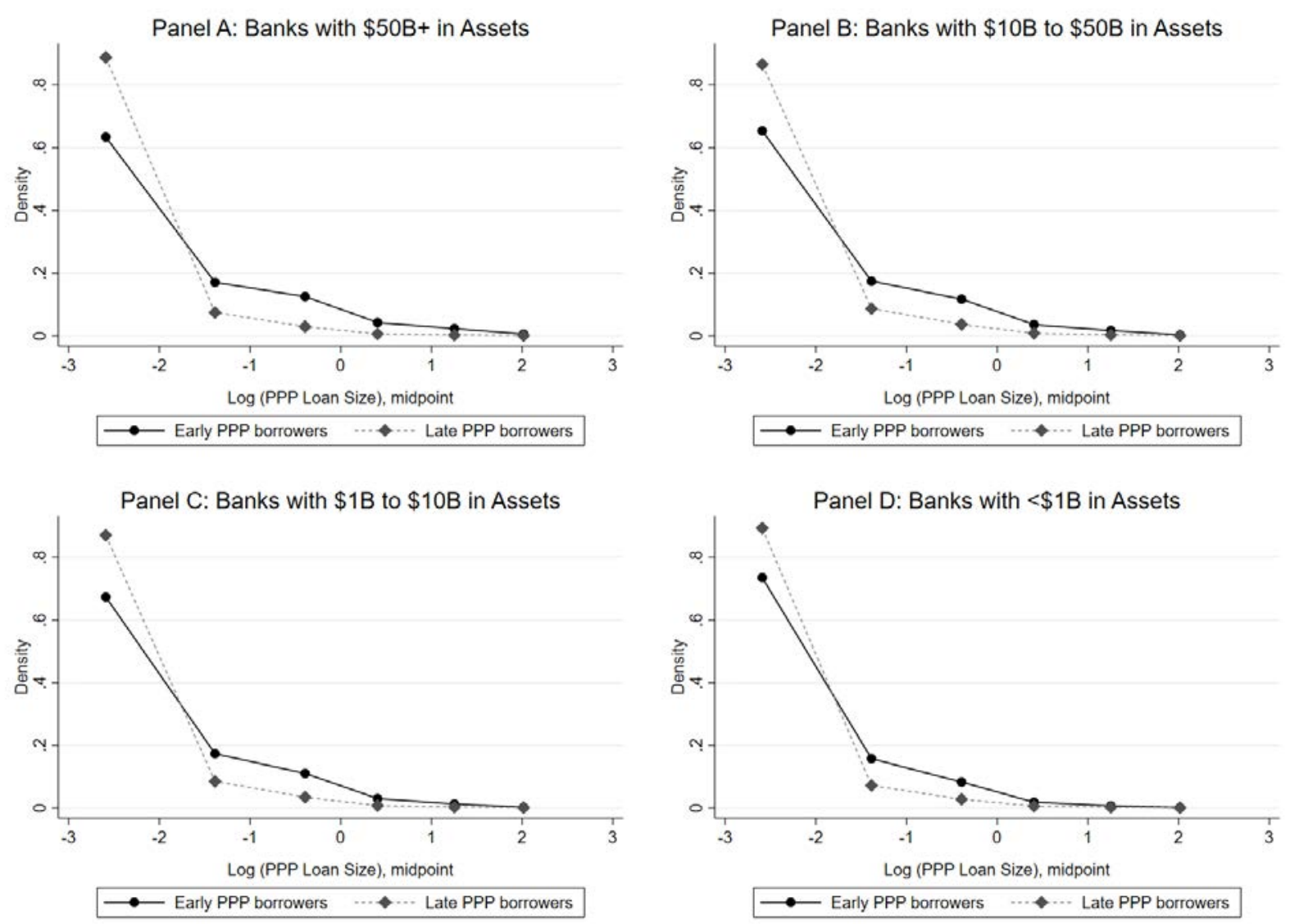

Figure B.3. PPP early borrowing and PPP loan size by bank size: SBA PPP data. This figure plots densities of a discrete PPP loan size variable which values are the natural logarithm of midpoints of PPP loan size bins (as binned by SBA). The sample is based on SBA PPP data, which we restrict to corporations, for comparability. Panel A reports the results for big-10 banks. Panel A reports the results for banks with $\$ 50 \mathrm{~B}+$ in assets. Panel B reports the results for banks with $\$ 10 \mathrm{~B}$ to $\$ 50 \mathrm{~B}$ in assets. Panel $\mathrm{C}$ reports the results for banks with $\$ 1 \mathrm{~B}$ to $\$ 10 \mathrm{~B}$ in assets. Panel D reports the results for banks with $<\$ 1 \mathrm{~B}$ in assets. Including other types of business does not affect the results. 


\title{
Internet Appendix to \\ "On the costs of being public and government aid:" Evidence from the Paycheck Protection Program"
}

Tetyana Balyuk, Nagpurnanand Prabhala, and Manju Puri

\author{
NOT FOR PUBLICATION
}

\section{Section IA.A: Additional Graphs and Tables}
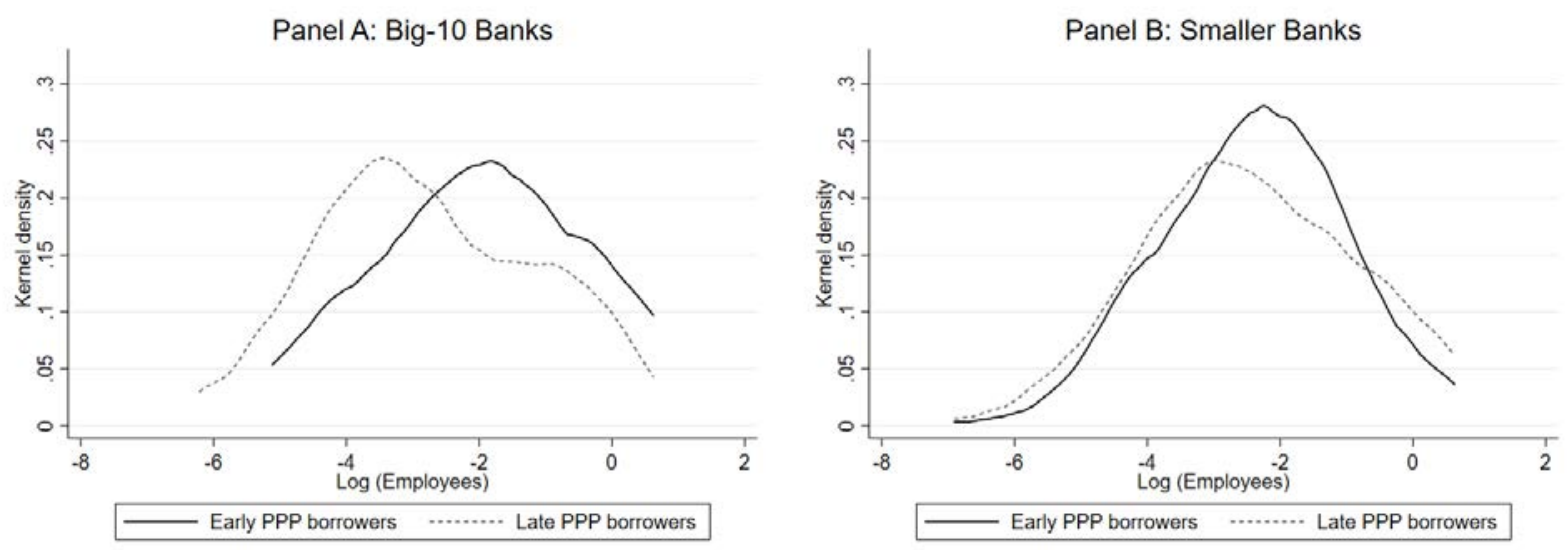

Figure IA.A.1. PPP early borrowing and firm employees by big-10 versus smaller banks. This figure plots kernel densities of the natural logarithm of the number of firm's employees for early versus late public PPP borrowers. Panel A reports the results for big-10 banks. Panel B reports the results for smaller (non-big-10) banks. Log (Employees) is winsorized at the $1^{\text {st }}$ and the $99^{\text {th }}$ percentiles. 

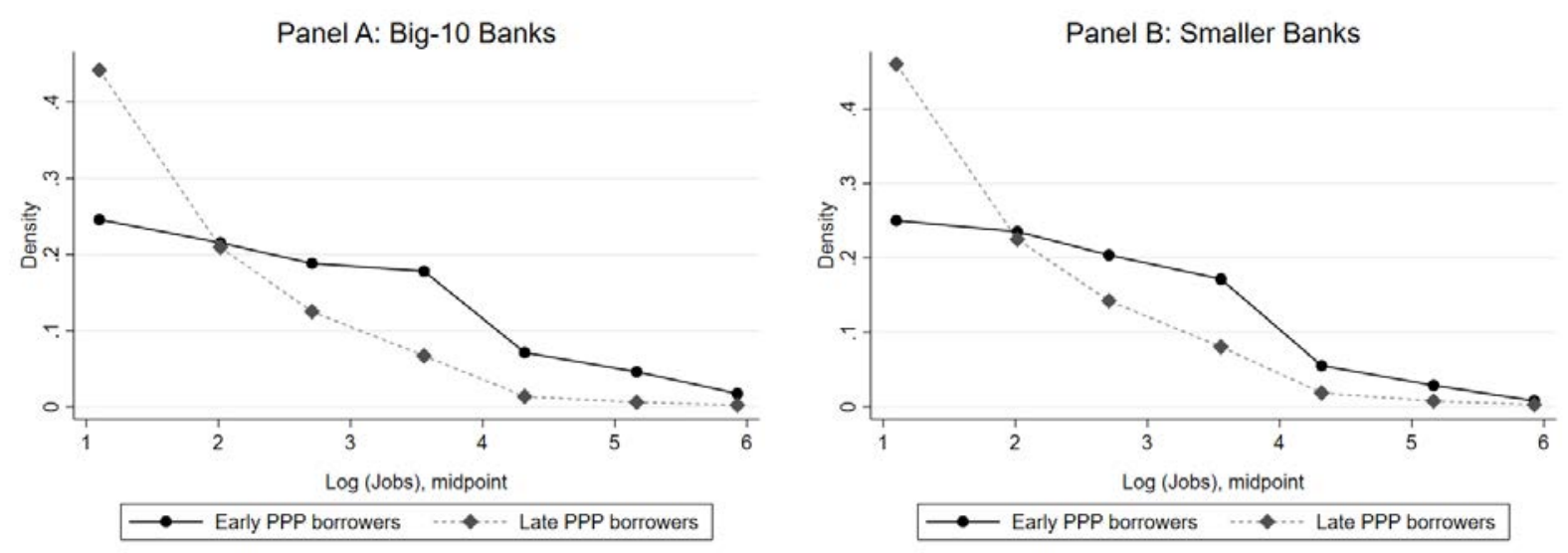

Figure IA.A.2. Early PPP borrowing and jobs by big-10 versus smaller banks: SBA PPP data. This figure plots densities of a discrete PPP loan size variable which values are the natural logarithm of midpoints of firm size class as measured by the number of jobs supported by PPP (binned as per BLS classification). We group the jobs variable into buckets using firm size classification by the Bureau of Labor Statistics (BLS) because the distribution of this variable is highly skewed even after log-transformation. The sample is based on SBA PPP data, which we restrict to corporations, for comparability. Panel A reports the results for big-10 banks. Panel B reports the results for smaller (non-big-10) banks, with this category including non-bank lenders. Excluding non-bank lenders or including other types of business does not affect the results. 
Table IA.A.1

\section{Early versus late borrowers and lender size Number of employees}

Columns (1) to (2) report the mean \# Employees for firms that obtained PPP loans in PPP Round 1 and PPP Round 2, respectively. Column (3) reports the number of observations and Column (4) reports p-values from a Wilcoxon rank sum test. Panel A compares big-10 banks (Big-10 Bank) to other banks (Smaller Bank). Panel B compares banks of different size, as measured by bank total assets. Book Value of Assets is winsorized at the $1^{\text {st }}$ and the $99^{\text {th }}$ percentiles.

\begin{tabular}{|c|c|c|c|c|}
\hline & \multicolumn{2}{|c|}{ Mean \# Employees ('000) } & \multicolumn{2}{|c|}{ Difference tests } \\
\hline & Early PPP borrowers & Late PPP borrowers & $\mathrm{N}$ & p-value \\
\hline & $(1)$ & $(2)$ & $(3)$ & $(4)$ \\
\hline \multicolumn{5}{|c|}{ Panel A: Big-10 Banks } \\
\hline Big-10 Banks & 0.376 & 0.196 & 153 & 0.002 \\
\hline Smaller Banks & 0.215 & 0.264 & 349 & 0.721 \\
\hline \multicolumn{5}{|c|}{ Panel B: Banks by Size } \\
\hline Banks with $\$ 50 \mathrm{~B}+$ in Assets & 0.274 & 0.194 & 287 & 0.012 \\
\hline Banks with $\$ 10 \mathrm{~B}$ to $\$ 50 \mathrm{~B}$ in Assets & 0.270 & 0.291 & 96 & 0.401 \\
\hline Banks with $\$ 1 \mathrm{~B}$ to $\$ 10 \mathrm{~B}$ in Assets & 0.197 & 0.403 & 55 & 0.784 \\
\hline Banks with $<\$ 1 \mathrm{~B}(1 / 0)$ in Assets & 0.192 & 0.269 & 64 & 0.307 \\
\hline
\end{tabular}




\section{Table IA.A.2 \\ Propensity to borrow early and big-10 banks}

This table reports the results from a linear probability (OLS) model where the dependent variable is an indicator for public company receiving a PPP loan before April 17, 2020 and the key independent variables are interactions between firm size and lender type dummies. Panel A reports the results for big-10 banks, which are JPMorgan Chase Bank, Wells Fargo Bank, Bank of America, Citibank, U.S. Bank, Truist Bank, PNC Bank, Bank of New York, State Street Corporation, and TD Bank (Big10 Bank), versus other banks (Smaller Bank, which is the excluded category). Panel B compares banks of different size, as measured by bank total assets (where Bank $[<\$ 1 B](1 / 0)$ is the excluded category). Continuous variables are winsorized at the $1^{\text {st }}$ and the $99^{\text {th }}$ percentiles. Standard errors are clustered at the industry level, defined as 2-digit NAICS, where we combine industries with few PPP-eligible companies into one bucket. ${ }^{* *}, * *$, and * denote statistical significance at the $1 \%$, $5 \%$, and $10 \%$ levels, respectively. $t$-statistics are presented in parentheses.

\begin{tabular}{|c|c|c|c|}
\hline & \multicolumn{3}{|c|}{ Dependent variable $=$ Early PPP Borrower $(1 / 0)$} \\
\hline & (1) & $(2)$ & $(3)$ \\
\hline \multicolumn{4}{|c|}{ Panel A: PPP loan size } \\
\hline Log (PPP Loan Amount) × Big-10 Bank (1/0) & $\begin{array}{c}0.110^{* * *} \\
(4.84)\end{array}$ & $\begin{array}{c}0.112^{* * *} \\
(4.91)\end{array}$ & $\begin{array}{c}0.114^{* * *} \\
(4.98)\end{array}$ \\
\hline Big-10 Bank (1/0) & $\begin{array}{c}-0.265^{* * *} \\
(-4.79)\end{array}$ & $\begin{array}{c}-0.265^{* * *} \\
(-4.90)\end{array}$ & $\begin{array}{c}-0.256 * * * \\
(-4.52)\end{array}$ \\
\hline Log (PPP Loan Amount) & $\begin{array}{c}-0.00321 \\
(-0.13)\end{array}$ & $\begin{array}{c}-0.00461 \\
(-0.17)\end{array}$ & $\begin{array}{c}0.00274 \\
(0.11)\end{array}$ \\
\hline Firm Characteristics & Yes & Yes & Yes \\
\hline Penny Stock Dummy & Yes & Yes & Yes \\
\hline Industry Dummies & - & Yes & Yes \\
\hline Returns Controls & - & - & Yes \\
\hline \# obs. & 483 & 483 & 475 \\
\hline Adjusted $\mathrm{R}^{2}$ & 0.0878 & 0.0827 & 0.0806 \\
\hline \multicolumn{4}{|c|}{ Panel B: Book value of assets } \\
\hline Log (Assets) $\times$ Big-10 Bank (1/0) & $\begin{array}{l}0.0740^{* * *} \\
(3.51)\end{array}$ & $\begin{array}{c}0.0743^{* * *} \\
(3.49)\end{array}$ & $\begin{array}{c}0.0716^{* * *} \\
(3.42)\end{array}$ \\
\hline Big-10 Bank (1/0) & $\begin{array}{c}-0.485^{* * *} \\
(-6.30)\end{array}$ & $\begin{array}{l}-0.486^{* * *} \\
(-6.25)\end{array}$ & $\begin{array}{c}-0.467^{* * *} \\
(-6.14)\end{array}$ \\
\hline Log (Assets) & $\begin{array}{c}-0.00866 \\
(-0.46)\end{array}$ & $\begin{array}{c}-0.00983 \\
(-0.51)\end{array}$ & $\begin{array}{c}-0.00361 \\
(-0.19)\end{array}$ \\
\hline Firm Characteristics & Yes & Yes & Yes \\
\hline Penny Stock Dummy & Yes & Yes & Yes \\
\hline Industry Dummies & - & Yes & Yes \\
\hline Returns Controls & - & - & Yes \\
\hline \# obs. & 483 & 483 & 475 \\
\hline Adjusted $\mathrm{R}^{2}$ & 0.0777 & 0.0713 & 0.0646 \\
\hline \multicolumn{4}{|c|}{ Panel C: Number of employees } \\
\hline Log (Employees) x Big-10 Bank (1/0) & $\begin{array}{l}0.0862^{* * *} \\
(4.46)\end{array}$ & $\begin{array}{c}0.0867 * * * \\
(4.45)\end{array}$ & $\begin{array}{l}0.0922^{* * *} \\
\quad(4.71)\end{array}$ \\
\hline Big-10 Bank (1/0) & $\begin{array}{c}-0.0219 \\
(-0.26)\end{array}$ & $\begin{array}{c}-0.0210 \\
(-0.26)\end{array}$ & $\begin{array}{c}0.000411 \\
(0.00)\end{array}$ \\
\hline Log (Employees) & $\begin{array}{r}-0.0227 \\
(-0.98)\end{array}$ & $\begin{array}{c}-0.0223 \\
(-0.93)\end{array}$ & $\begin{array}{c}-0.0187 \\
(-0.81)\end{array}$ \\
\hline Firm Characteristics & Yes & Yes & Yes \\
\hline Penny Stock Dummy & Yes & Yes & Yes \\
\hline Industry Dummies & - & Yes & Yes \\
\hline Returns Controls & - & - & Yes \\
\hline No. obs. & 478 & 478 & 470 \\
\hline Adjusted $R^{2}$ & 0.0783 & 0.0725 & 0.0690 \\
\hline
\end{tabular}




\section{Table IA.A.3 \\ Propensity to borrow early and big-10 banks: SBA PPP data PPP loan size}

This table reports the results from a linear probability (OLS) model based on SBA PPP data where the dependent variable is a dummy for an early PPP borrower. The key independent variables are interactions between PPP loan size bin dummies (as binned by SBA) and a dummy for a big-10 bank, Big-10 Bank. We classify the following banks as big-10 banks: JPMorgan Chase Bank, Wells Fargo Bank, Bank of America, Citibank, U.S. Bank, Truist Bank, PNC Bank, Bank of New York, State Street Corporation, and TD Bank. Continuous variables are winsorized at the $1^{\text {st }}$ and the $99^{\text {th }}$ percentiles. Standard errors are clustered at the industry level, defined as 2-digit NAICS. ***, $* *$, and $*$ denote statistical significance at the $1 \%, 5 \%$, and $10 \%$ levels, respectively. $t$-statistics are presented in parentheses.

\begin{tabular}{|c|c|c|c|c|}
\hline & \multicolumn{4}{|c|}{ Dependent variable $=$ Early PPP Borrower $(1 / 0)$} \\
\hline & \multicolumn{2}{|c|}{ All Firms } & \multicolumn{2}{|c|}{ Only Corporations } \\
\hline & $(1)$ & $(2)$ & $(3)$ & $(4)$ \\
\hline Big-10 Bank $(1 / 0) \times$ Loan $[\$ 5-10 \mathrm{M}](1 / 0)$ & $\begin{array}{c}0.151^{* * *} \\
(10.34)\end{array}$ & $\begin{array}{c}0.191^{* * *} \\
(15.57)\end{array}$ & $\begin{array}{c}0.161 * * * \\
(5.82)\end{array}$ & $\begin{array}{c}0.183^{* * *} \\
(8.69)\end{array}$ \\
\hline $\operatorname{Big}-10 \operatorname{Bank}(1 / 0) \quad \times$ Loan $[\$ 2-5 \mathrm{M}](1 / 0)$ & $\begin{array}{l}0.104^{* * *} \\
(6.70)\end{array}$ & $\begin{array}{c}0.137^{* * *} \\
(8.53)\end{array}$ & $\begin{array}{l}0.0825^{* * *} \\
(6.19)\end{array}$ & $\begin{array}{c}0.123^{* * *} \\
(10.28)\end{array}$ \\
\hline Big-10 Bank $(1 / 0) \quad \times$ Loan $[\$ 1-2 \mathrm{M}](1 / 0)$ & $\begin{array}{l}0.0651^{* * *} \\
\quad(3.09)\end{array}$ & $\begin{array}{l}0.0986^{* * *} \\
(4.33)\end{array}$ & $\begin{array}{c}0.0382^{*} \\
(1.82)\end{array}$ & $\begin{array}{l}0.0761^{* * *} \\
\quad(3.53)\end{array}$ \\
\hline Big-10 Bank $(1 / 0) \times$ Loan $[\$ 350 \mathrm{k}-1 \mathrm{M}](1 / 0)$ & $\begin{array}{c}-0.0340^{*} \\
(-1.96)\end{array}$ & $\begin{array}{l}-0.000544 \\
(-0.03)\end{array}$ & $\begin{array}{l}-0.0529^{* * *} \\
(-4.64)\end{array}$ & $\begin{array}{c}-0.0121 \\
(-0.99)\end{array}$ \\
\hline $\operatorname{Big}-10 \operatorname{Bank}(1 / 0) \times$ Loan $[\$ 150-350 \mathrm{k}](1 / 0)$ & $\begin{array}{c}-0.113^{* * *} \\
(-10.44)\end{array}$ & $\begin{array}{c}-0.0841^{* * *} \\
(-9.36)\end{array}$ & $\begin{array}{c}-0.103^{* * *} \\
(-13.66)\end{array}$ & $\begin{array}{c}-0.0678^{* * *} \\
(-11.62)\end{array}$ \\
\hline Loan $[\$ 5-10 \mathrm{M}](1 / 0)$ & $\begin{array}{c}0.366^{* * *} \\
(10.87)\end{array}$ & $\begin{array}{c}0.306^{* * *} \\
(10.71)\end{array}$ & $\begin{array}{l}0.329^{* * *} \\
(9.28)\end{array}$ & $\begin{array}{c}0.281^{* * *} \\
(10.34)\end{array}$ \\
\hline Loan $[\$ 2-5 \mathrm{M}](1 / 0)$ & $\begin{array}{c}0.418^{* * *} \\
(19.62)\end{array}$ & $\begin{array}{c}0.351^{* * *} \\
(19.15)\end{array}$ & $\begin{array}{c}0.391^{* * *} \\
(23.33)\end{array}$ & $\begin{array}{c}0.323^{* * *} \\
(23.20)\end{array}$ \\
\hline Loan $[\$ 1-2 \mathrm{M}](1 / 0)$ & $\begin{array}{c}0.384^{* * *} \\
(18.31)\end{array}$ & $\begin{array}{c}0.318^{* * *} \\
(17.82)\end{array}$ & $\begin{array}{c}0.364^{* * *} \\
(24.58)\end{array}$ & $\begin{array}{c}0.295^{* * *} \\
(24.83)\end{array}$ \\
\hline Loan $[\$ 350 \mathrm{k}-1 \mathrm{M}](1 / 0)$ & $\begin{array}{c}0.344^{* * *} \\
(25.35)\end{array}$ & $\begin{array}{c}0.283^{* * *} \\
(24.34)\end{array}$ & $\begin{array}{c}0.317^{* * *} \\
(30.76)\end{array}$ & $\begin{array}{c}0.252^{* * *} \\
(31.23)\end{array}$ \\
\hline Loan $[\$ 150-350 \mathrm{k}](1 / 0)$ & $\begin{array}{c}0.265^{* * *} \\
(28.57)\end{array}$ & $\begin{array}{c}0.215^{* * *} \\
(25.06)\end{array}$ & $\begin{array}{c}0.232^{* * * *} \\
(30.48)\end{array}$ & $\begin{array}{c}0.179^{* * *} \\
(27.61)\end{array}$ \\
\hline Big-10 Bank (1/0) & $\begin{array}{c}-0.199 * * * \\
(-29.66)\end{array}$ & & $\begin{array}{c}-0.254^{* * *} \\
(-44.23) \\
\end{array}$ & \\
\hline NAICS-2 \& ZIP-5 FE & Yes & Yes & Yes & Yes \\
\hline Business Type FE & Yes & Yes & - & - \\
\hline Lender FE & - & Yes & - & Yes \\
\hline \# obs. & $5,072,295$ & $5,072,272$ & $1,452,292$ & $1,452,147$ \\
\hline Adjusted $\mathrm{R}^{2}$ & 0.233 & 0.360 & 0.257 & 0.394 \\
\hline
\end{tabular}




\section{Table IA.A.4 \\ Propensity to borrow early and big-10 banks: SBA PPP data Jobs supported by PPP}

This table reports the results from a linear probability (OLS) model based on SBA PPP data where the dependent variable is a dummy for an early PPP borrower. The key independent variables are interactions between the number of jobs supported by PPP (binned as per BLS classification) and a dummy for a big-10 bank, Big-10 Bank. We group the jobs variable into buckets using firm size classification by the Bureau of Labor Statistics (BLS) because the distribution of this variable is highly skewed even after log-transformation. Continuous variables are winsorized at the $1^{\text {st }}$ and the $99^{\text {th }}$ percentiles. Standard errors are clustered at the industry level, defined as 2-digit NAICS. ***, $* *$, and $*$ denote statistical significance at the $1 \%, 5 \%$, and $10 \%$ levels, respectively. $t$-statistics are presented in parentheses.

\begin{tabular}{|c|c|c|c|c|c|}
\hline & & \multicolumn{4}{|c|}{ Dependent variable $=$ Early PPP Borrower $(1 / 0)$} \\
\hline & & \multicolumn{2}{|c|}{ All Firms } & \multicolumn{2}{|c|}{ Only Corporations } \\
\hline & & $(1)$ & $(2)$ & $(3)$ & (4) \\
\hline Big-10 Bank (1/0) & $\times$ Jobs $[250+](1 / 0)$ & $\begin{array}{c}0.0351^{* *} \\
(2.23)\end{array}$ & $\begin{array}{l}0.0104 \\
(0.55)\end{array}$ & $\begin{array}{c}0.00215 \\
(0.10)\end{array}$ & $\begin{array}{c}-0.00477 \\
(-0.23)\end{array}$ \\
\hline Big-10 Bank (1/0) & $\times$ Jobs [100-249] $(1 / 0)$ & $\begin{array}{c}0.00821 \\
(0.40)\end{array}$ & $\begin{array}{c}-0.0109 \\
(-0.47)\end{array}$ & $\begin{array}{c}-0.0293 \\
(-1.43)\end{array}$ & $\begin{array}{c}-0.0374 \\
(-1.62)\end{array}$ \\
\hline Big-10 Bank (1/0) & $\times$ Jobs [50-99] $(1 / 0)$ & $\begin{array}{c}-0.0541^{* *} \\
(-2.34)\end{array}$ & $\begin{array}{c}-0.0715^{* * *} \\
(-3.00)\end{array}$ & $\begin{array}{c}-0.0719^{* * *} \\
(-3.67)\end{array}$ & $\begin{array}{c}-0.0763^{* * *} \\
(-3.87)\end{array}$ \\
\hline Big-10 Bank (1/0) & $\times$ Jobs $[20-49](1 / 0)$ & $\begin{array}{c}-0.133^{* * *} \\
(-9.82)\end{array}$ & $\begin{array}{c}-0.137^{* * *} \\
(-11.48)\end{array}$ & $\begin{array}{c}-0.136^{* * *} \\
(-11.04)\end{array}$ & $\begin{array}{c}-0.127^{* * *} \\
(-12.10)\end{array}$ \\
\hline Big-10 Bank (1/0) & $\times$ Jobs $[10-19](1 / 0)$ & $\begin{array}{c}-0.147^{* * *} \\
(-16.56)\end{array}$ & $\begin{array}{c}-0.137 * * * \\
(-17.51)\end{array}$ & $\begin{array}{c}-0.133^{* * * *} \\
(-14.97)\end{array}$ & $\begin{array}{c}-0.113^{* * *} \\
(-16.06)\end{array}$ \\
\hline Big-10 Bank (1/0) & $\times$ Jobs $[5-9](1 / 0)$ & $\begin{array}{c}-0.126^{* * *} \\
(-18.00)\end{array}$ & $\begin{array}{c}-0.112^{* * *} \\
(-16.66)\end{array}$ & $\begin{array}{c}-0.100^{* * *} \\
(-14.54)\end{array}$ & $\begin{array}{c}-0.0817^{* * *} \\
(-14.13)\end{array}$ \\
\hline Jobs [250+] (1/0) & & $\begin{array}{c}0.436^{* * *} \\
(14.75)\end{array}$ & $\begin{array}{c}0.364^{* * *} \\
(14.83)\end{array}$ & $\begin{array}{c}0.408^{* * *} \\
(16.38)\end{array}$ & $\begin{array}{c}0.331^{* * *} \\
(15.93)\end{array}$ \\
\hline Jobs $[100-249](1 / 0)$ & & $\begin{array}{c}0.451^{* * * *} \\
(16.78)\end{array}$ & $\begin{array}{c}0.375^{* * * *} \\
(16.31)\end{array}$ & $\begin{array}{c}0.434^{* * * *} \\
(21.99)\end{array}$ & $\begin{array}{c}0.348^{* * *} \\
(20.58)\end{array}$ \\
\hline Jobs [50-99] $(1 / 0)$ & & $\begin{array}{c}0.422^{* * *} \\
(22.42)\end{array}$ & $\begin{array}{c}0.350^{* * *} \\
(22.17)\end{array}$ & $\begin{array}{c}0.396^{* * *} \\
(26.20)\end{array}$ & $\begin{array}{c}0.314^{* * *} \\
(25.89)\end{array}$ \\
\hline Jobs [20-49] (1/0) & & $\begin{array}{c}0.354^{* * *} \\
(34.06)\end{array}$ & $\begin{array}{c}0.292^{* * *} \\
(29.66)\end{array}$ & $\begin{array}{c}0.327^{* * *} \\
(34.35)\end{array}$ & $\begin{array}{c}0.253^{* * *} \\
(28.26)\end{array}$ \\
\hline Jobs [10-19] $(1 / 0)$ & & $\begin{array}{c}0.260^{* * *} \\
(34.89)\end{array}$ & $\begin{array}{c}0.214^{* * *} \\
(28.16)\end{array}$ & $\begin{array}{c}0.233^{* * *} \\
(33.42)\end{array}$ & $\begin{array}{c}0.179^{* * *} \\
(26.39)\end{array}$ \\
\hline Jobs $[5-9](1 / 0)$ & & $\begin{array}{c}0.181^{* * *} \\
(26.29)\end{array}$ & $\begin{array}{c}0.151^{* * * *} \\
(22.46)\end{array}$ & $\begin{array}{c}0.153^{* * * *} \\
(28.76)\end{array}$ & $\begin{array}{c}0.116^{* * *} \\
(24.20)\end{array}$ \\
\hline Big-10 Bank (1/0) & & $\begin{array}{c}-0.139 * * * \\
(-17.26) \\
\end{array}$ & & $\begin{array}{c}-0.176^{* * *} \\
(-18.55) \\
\end{array}$ & \\
\hline NAICS-2 \& ZIP-5 F & & Yes & Yes & Yes & Yes \\
\hline Business Type FE & & Yes & Yes & - & - \\
\hline Lender FE & & - & Yes & - & Yes \\
\hline \# obs. & & $4,168,387$ & $4,168,332$ & $1,190,856$ & $1,190,682$ \\
\hline Adjusted $\mathrm{R}^{2}$ & & 0.247 & 0.376 & 0.252 & 0.396 \\
\hline
\end{tabular}




\section{Table IA.A.5}

\section{Early PPP borrowers and lender effects \\ Number of employees}

This table reports the results from a multinomial logit model for public PPP recipients where the dependent variable is a categorical variable for the intersection between a bank type (big-10 bank versus smaller bank) and borrower type (early versus late PPP borrower). The independent variable is the natural logarithm of the number of firm's employees. The dependent variable Bank Type-Borrower Type Category $(Y)$ takes the value of 3 for big-10 bank and early PPP borrower, 2 for big-10 bank and late PPP borrower, 1 for smaller bank and early PPP borrower, and 0 for smaller bank and late PPP borrower. We classify the following banks as big-10 banks: JPMorgan Chase Bank, Wells Fargo Bank, Bank of America, Citibank, U.S. Bank, Truist Bank, PNC Bank, Bank of New York, State Street Corporation, and TD Bank. An early borrower is a public company receiving a PPP loan before April 17, 2020. Continuous variables are winsorized at the $1^{\text {st }}$ and the $99^{\text {th }}$ percentiles. Standard errors are clustered at the industry level, defined as 2-digit NAICS, where we combine industries with few PPP-eligible companies into one bucket. ***, **, and * denote statistical significance at the $1 \%, 5 \%$, and $10 \%$ levels, respectively. $z$-statistics are presented in parentheses.

\begin{tabular}{llcc}
\hline & \multicolumn{3}{c}{ Dependent variable = Bank Type-Borrower Type Category (Y) } \\
\cline { 2 - 4 } & \multicolumn{1}{c}{ Predictor } & Coefficient & z-statistic \\
\hline Y = 3: Big-10 Bank-Early PPP Borrower & \multicolumn{1}{c}{ Log (Employees) } & $(2)$ & $(3)$ \\
Y = 2: Big-10 Bank-Late PPP Borrower & Log (Employees) & $0.209^{* * *}$ & $(3.07)$ \\
Y = 1: Smaller Bank-Early PPP Borrower & [Base outcome] & $-0.169^{* *}$ & $(-2.41)$ \\
Y=0: Smaller Bank-Late PPP Borrower & Log (Employees) & - & - \\
\hline \# obs. & 502 & -0.0195 & $(-0.16)$ \\
Pseudo- $R^{2}$ & 0.00997 & & \\
Log-likelihood & -607.7 & & \\
\hline
\end{tabular}




\section{Table IA.A.6 \\ Early PPP borrowers and lender effects: SBA PPP data Jobs supported by PPP}

This table reports the results from a multinomial logit model based on SBA PPP data where the dependent variable is a categorical variable for the intersection between a bank type (big-10 bank versus smaller bank) and borrower type (early versus late PPP borrower). The independent variable is the number of jobs supported by PPP (binned as per BLS classification). We group the jobs variable into buckets using firm size classification by the Bureau of Labor Statistics (BLS) because the distribution of this variable is highly skewed even after log-transformation. The dependent variable Bank Type-Borrower Type Category ( $Y$ ) takes the value of 3 for big-10 bank and early PPP borrower, 2 for big-10 bank and late PPP borrower, 1 for smaller bank and early PPP borrower, and 0 for smaller bank and late PPP borrower. We classify the following banks as big-10 banks: JPMorgan Chase Bank, Wells Fargo Bank, Bank of America, Citibank, U.S. Bank, Truist Bank, PNC Bank, Bank of New York, State Street Corporation, and TD Bank. An early borrower is a public company receiving a PPP loan before April 17, 2020. Continuous variables are winsorized at the $1^{\text {st }}$ and the $99^{\text {th }}$ percentiles. Standard errors are clustered at the industry level, defined as 2-digit NAICS, where we combine industries with few PPP-eligible companies into one bucket. ***, $* *$, and $*$ denote statistical significance at the $1 \%, 5 \%$, and $10 \%$ levels, respectively. $z$-statistics are presented in parentheses.

\begin{tabular}{|c|c|c|c|}
\hline & \multicolumn{3}{|c|}{ Dependent variable $=$ Bank Type-Borrower Type Category $(\mathrm{Y})$} \\
\hline & Predictor & Coefficient & z-statistic \\
\hline & $(1)$ & $(2)$ & $(3)$ \\
\hline \multicolumn{4}{|c|}{$\mathrm{Y}=3:$ Big-10 Bank-Early PPP Borrower } \\
\hline & Jobs $[250+](1 / 0)$ & $0.766^{* * *}$ & $(8.94)$ \\
\hline & Jobs [100-249] $(1 / 0)$ & $0.492^{* * *}$ & $(4.74)$ \\
\hline & Jobs $[50-99](1 / 0)$ & $0.272^{* * *}$ & $(2.67)$ \\
\hline & Jobs [20-49] $(1 / 0)$ & 0.0552 & $(0.78)$ \\
\hline & Jobs $[10-19](1 / 0)$ & -0.0620 & $(-1.04)$ \\
\hline & Jobs $[5-9](1 / 0)$ & -0.0704 & $(-1.31)$ \\
\hline \multicolumn{4}{|c|}{$\mathrm{Y}=2:$ Big-10 Bank-Late PPP Borrower } \\
\hline & Jobs $[250+](1 / 0)$ & $-1.823^{* * *}$ & $(-14.78)$ \\
\hline & Jobs [100-249] $(1 / 0)$ & $-2.104^{* * *}$ & $(-20.53)$ \\
\hline & Jobs $[50-99](1 / 0)$ & $-1.962^{* * *}$ & $(-22.67)$ \\
\hline & Jobs $[20-49](1 / 0)$ & $-1.500 * * *$ & $(-22.87)$ \\
\hline & Jobs $[10-19](1 / 0)$ & $-1.051^{* * *}$ & $(-20.80)$ \\
\hline & Jobs $[5-9](1 / 0)$ & $-0.675^{* * *}$ & $(-14.09)$ \\
\hline \multicolumn{4}{|c|}{$\mathrm{Y}=1$ : Smaller Bank-Early PPP Borrower } \\
\hline \multirow{2}{*}{\multicolumn{4}{|c|}{$\mathrm{Y}=0:$ Smaller Bank-Late PPP Borrower }} \\
\hline & & & \\
\hline & Jobs $[250+](1 / 0)$ & $-1.692^{* * *}$ & $(-14.13)$ \\
\hline & Jobs $[100-249](1 / 0)$ & $-1.911^{* * *}$ & $(-18.84)$ \\
\hline & Jobs [50-99] $(1 / 0)$ & $-1.700^{* * *}$ & $(-21.10)$ \\
\hline & Jobs [20-49] $(1 / 0)$ & $-1.363^{* * *}$ & $(-22.62)$ \\
\hline & Jobs $[10-19](1 / 0)$ & $-0.968^{* * *}$ & $(-19.79)$ \\
\hline & Jobs $[5-9](1 / 0)$ & $-0.653^{* * *}$ & $(-19.64)$ \\
\hline \# obs. & $1,195,814$ & & \\
\hline Pseudo- $R^{2}$ & 0.0343 & & \\
\hline Log-likelihood & -1365000 & & \\
\hline
\end{tabular}




\section{Section IA.B: Robustness}

\section{Table IA.B.1 \\ PPP borrowing propensity \\ Firms with market cap $\geq \$ 50$ million}

This table reports the results from a linear probability (OLS) model where the dependent variable is an indicator for public company receiving a PPP loan and independent variables are company characteristics, for the subsample of firms that have market capitalization of at least $\$ 50$ million. Continuous variables are winsorized at the $1^{\text {st }}$ and the $99^{\text {th }}$ percentiles. Standard errors are clustered at the industry level, defined as 2-digit NAICS, where we combine industries with few PPP-eligible companies into one bucket. ${ }^{* *}, * *$, and * denote statistical significance at the $1 \%, 5 \%$, and $10 \%$ levels, respectively. $t$-statistics are presented in parentheses.

\begin{tabular}{|c|c|c|c|}
\hline & \multicolumn{3}{|c|}{ Dependent variable $=$ PPP Borrower $(1 / 0)$} \\
\hline & (1) & $(2)$ & $(3)$ \\
\hline Log (Assets) & $\begin{array}{c}-0.0658^{* * * *} \\
(-4.34)\end{array}$ & $\begin{array}{c}-0.0602^{* * *} \\
(-4.87)\end{array}$ & $\begin{array}{c}-0.0627^{* * *} \\
(-4.18)\end{array}$ \\
\hline Log (Age) & $\begin{array}{c}0.0609^{* *} \\
(2.80)\end{array}$ & $\begin{array}{c}0.0533^{*} \\
(2.09)\end{array}$ & $\begin{array}{c}0.0539^{*} \\
(2.01)\end{array}$ \\
\hline Book Equity $<0(1 / 0)$ & $\begin{array}{c}-0.0277 \\
(-0.68)\end{array}$ & $\begin{array}{c}-0.0151 \\
(-0.33)\end{array}$ & $\begin{array}{c}-0.0247 \\
(-0.43)\end{array}$ \\
\hline Tobin's Q & $\begin{array}{c}-0.0134^{* * *} \\
(-4.20)\end{array}$ & $\begin{array}{c}-0.0122^{* * *} \\
(-3.78)\end{array}$ & $\begin{array}{c}-0.0119 * * * \\
(-3.41)\end{array}$ \\
\hline Current Ratio & $\begin{array}{c}-0.00796 * * * \\
(-4.46)\end{array}$ & $\begin{array}{c}-0.00746^{* * *} \\
(-3.25)\end{array}$ & $\begin{array}{c}-0.00697^{* * *} \\
(-3.28)\end{array}$ \\
\hline Cash/Non-Cash Assets & $\begin{array}{c}-0.00379 * * * \\
(-3.13)\end{array}$ & $\begin{array}{c}-0.00277^{* *} \\
(-2.67)\end{array}$ & $\begin{array}{c}-0.00283^{* *} \\
(-2.49)\end{array}$ \\
\hline Penny Stock $(1 / 0)$ & $\begin{array}{c}-0.0603 \\
(-1.29)\end{array}$ & $\begin{array}{c}-0.0517 \\
(-1.43)\end{array}$ & $\begin{array}{c}0.00617 \\
(0.21)\end{array}$ \\
\hline Covid Industry $(1 / 0)$ & & $\begin{array}{l}0.137 \\
(1.24)\end{array}$ & $\begin{array}{l}0.136 \\
(1.17)\end{array}$ \\
\hline Machinery Industry $(1 / 0)$ & & $\begin{array}{c}0.244^{* * *} \\
(3.80)\end{array}$ & $\begin{array}{c}0.248^{* * *} \\
(3.49)\end{array}$ \\
\hline Health Industry $(1 / 0)$ & & $\begin{array}{c}-0.0223 \\
(-0.28)\end{array}$ & $\begin{array}{c}-0.00790 \\
(-0.10)\end{array}$ \\
\hline High-Tech Industry $(1 / 0)$ & & $\begin{array}{c}0.0860 \\
(0.71)\end{array}$ & $\begin{array}{l}0.101 \\
(0.87)\end{array}$ \\
\hline Covid Period Return & & & $\begin{array}{l}-0.183 \\
(-1.70)\end{array}$ \\
\hline Covid Period Return $\times$ Penny Stock $(1 / 0)$ & & & $\begin{array}{c}0.0683 \\
(0.98)\end{array}$ \\
\hline Stimulus Day Return & & & $\begin{array}{l}0.298 \\
(0.94)\end{array}$ \\
\hline Stimulus Day Return $\times$ Penny Stock $(1 / 0)$ & & & $\begin{array}{l}-0.365 \\
(-1.15)\end{array}$ \\
\hline \# obs. & 1,049 & 1,049 & 1,029 \\
\hline Adjusted $\mathrm{R}^{2}$ & 0.113 & 0.125 & 0.130 \\
\hline
\end{tabular}


Table IA.B.2

\section{PPP borrowing propensity and distance-to-default}

This table reports the results from a linear probability (OLS) model where the dependent variable is an indicator for public company receiving a PPP loan and independent variables are Distanceto-Default and other company characteristics. Continuous variables are winsorized at the $1^{\text {st }}$ and the $99^{\text {th }}$ percentiles. Standard errors are clustered at the industry level, defined as 2-digit NAICS, where we combine industries with few PPP-eligible companies into one bucket. ***, **, and * denote statistical significance at the $1 \%, 5 \%$, and $10 \%$ levels, respectively. $t$-statistics are presented in parentheses.

\begin{tabular}{|c|c|c|c|}
\hline & \multicolumn{3}{|c|}{ Dependent variable $=$ PPP Borrower $(1 / 0)$} \\
\hline & (1) & $(2)$ & $(3)$ \\
\hline Distance-to-Default & $\begin{array}{c}-0.0152 \\
(-1.74)\end{array}$ & $\begin{array}{c}-0.0223^{* *} \\
(-2.86)\end{array}$ & $\begin{array}{c}-0.0216^{* *} \\
(-2.97)\end{array}$ \\
\hline Log (Assets) & $\begin{array}{c}-0.0848^{* * * *} \\
(-9.92)\end{array}$ & $\begin{array}{c}-0.0843^{* * *} \\
(-9.39)\end{array}$ & $\begin{array}{c}-0.0878^{* * *} \\
(-11.26)\end{array}$ \\
\hline Log (Age) & $\begin{array}{c}0.0726 * * * \\
(4.93)\end{array}$ & $\begin{array}{c}0.0535^{* *} \\
(2.51)\end{array}$ & $\begin{array}{c}0.0545^{* *} \\
(2.37)\end{array}$ \\
\hline Book Equity $<0(1 / 0)$ & $\begin{array}{c}-0.0569 \\
(-1.26)\end{array}$ & $\begin{array}{c}-0.0409 \\
(-0.69)\end{array}$ & $\begin{array}{c}-0.0473 \\
(-0.78)\end{array}$ \\
\hline Tobin's Q & $\begin{array}{c}-0.0210^{* * * *} \\
(-4.72)\end{array}$ & $\begin{array}{c}-0.0142^{*} \\
(-1.96)\end{array}$ & $\begin{array}{c}-0.0132^{*} \\
(-1.85)\end{array}$ \\
\hline Current Ratio & $\begin{array}{c}-0.00981^{* * *} \\
(-5.97)\end{array}$ & $\begin{array}{c}-0.00632^{* * * *} \\
(-3.66)\end{array}$ & $\begin{array}{c}-0.00577^{* * * *} \\
(-3.78)\end{array}$ \\
\hline Cash/Non-Cash Assets & $\begin{array}{c}-0.00884 * * * \\
(-3.41)\end{array}$ & $\begin{array}{c}-0.00568^{* *} \\
(-2.75)\end{array}$ & $\begin{array}{c}-0.00596 * * * \\
(-3.20)\end{array}$ \\
\hline Penny Stock $(1 / 0)$ & $\begin{array}{c}0.0347 \\
(1.30)\end{array}$ & $\begin{array}{c}0.0253 \\
(0.80)\end{array}$ & $\begin{array}{c}0.0770 \\
(0.95)\end{array}$ \\
\hline Covid Industry $(1 / 0)$ & & $\begin{array}{c}0.205^{* *} \\
(2.70)\end{array}$ & $\begin{array}{c}0.205^{* *} \\
(2.47)\end{array}$ \\
\hline Machinery Industry $(1 / 0)$ & & $\begin{array}{c}0.167^{* *} \\
(2.87)\end{array}$ & $\begin{array}{c}0.171^{* *} \\
(2.86)\end{array}$ \\
\hline Health Industry $(1 / 0)$ & & $\begin{array}{c}-0.168^{*} \\
(-1.88)\end{array}$ & $\begin{array}{l}-0.157 \\
(-1.70)\end{array}$ \\
\hline High-Tech Industry $(1 / 0)$ & & $\begin{array}{l}0.0625 \\
(0.59)\end{array}$ & $\begin{array}{c}0.0596 \\
(0.57)\end{array}$ \\
\hline Covid Period Return & & & $\begin{array}{l}-0.177 \\
(-1.47)\end{array}$ \\
\hline Covid Period Return × Penny Stock $(1 / 0)$ & & & $\begin{array}{c}0.0434 \\
(0.46)\end{array}$ \\
\hline Stimulus Day Return & & & $\begin{array}{l}0.241 \\
(0.69)\end{array}$ \\
\hline Stimulus Day Return $\times$ Penny Stock $(1 / 0)$ & & & $\begin{array}{l}-0.434 \\
(-1.27)\end{array}$ \\
\hline \# obs. & 950 & 950 & 946 \\
\hline Adjusted $\mathrm{R}^{2}$ & 0.214 & 0.261 & 0.269 \\
\hline
\end{tabular}




\section{Table IA.B.3 \\ PPP loan grant announcement effects \\ Firms with market cap $\geq \$ 50$ million}

This table reports the results from a event study analysis where the dependent variable is the company's stock return measured as stock return minus S\&P 500 return (Panel A) or abnormal stock return calculated using the market model based on S\&P 500 return (Panel B), for the subsample of firms that have market capitalization of at least $\$ 50$ million. The key independent variable Day is an indicator for the treading day relative to the PPP loan grant announcement date, Day 0 (e.g., $8-\mathrm{K}$ filing, press release). The time period is from Day -60 to Day +1 . The estimation window for the market model is Day -270 to Day -61. The day count excludes non-trading days (e.g., weekends, holidays). Continuous variables are winsorized at the $1^{\text {st }}$ and the $99^{\text {th }}$ percentiles. Standard errors are clustered at the trading day level. ***, **, and * denote statistical significance at the $1 \%, 5 \%$, and $10 \%$ levels, respectively. $t$-statistics are presented in parentheses.

\begin{tabular}{|c|c|c|c|c|c|c|}
\hline & \multicolumn{3}{|c|}{ Panel A: Market-adjusted } & \multicolumn{3}{|c|}{ Panel B: Market model } \\
\hline & Day -1 & Day 0 & Day +1 & Day -1 & Day 0 & Day +1 \\
\hline & $(1)$ & $(2)$ & $(3)$ & $(4)$ & $(5)$ & $(6)$ \\
\hline \multicolumn{7}{|c|}{ Panel A: All observations } \\
\hline \multicolumn{7}{|l|}{ Across firms: } \\
\hline $\begin{array}{l}\text { Abnormal return } \\
\text { t-statistic }\end{array}$ & $\begin{array}{l}0.0119 * * \\
(2.17)\end{array}$ & $\begin{array}{c}0.000848 \\
(0.15)\end{array}$ & $\begin{array}{c}0.00905 \\
(1.50)\end{array}$ & $\begin{array}{c}0.0123^{* *} \\
(2.26)\end{array}$ & $\begin{array}{c}0.00292 \\
(0.48)\end{array}$ & $\begin{array}{c}0.0111^{*} \\
(1.76)\end{array}$ \\
\hline \multicolumn{7}{|l|}{ Within firms: } \\
\hline $\begin{array}{l}\text { Abnormal return } \\
\text { t-statistic }\end{array}$ & $\begin{array}{c}0.0119^{* *} \\
(2.16)\end{array}$ & $\begin{array}{c}0.000854 \\
(0.15)\end{array}$ & $\begin{array}{c}0.00907 \\
(1.47)\end{array}$ & $\begin{array}{l}0.0123^{* *} \\
(2.27)\end{array}$ & $\begin{array}{c}0.00296 \\
(0.48)\end{array}$ & $\begin{array}{c}0.0112^{*} \\
(1.72)\end{array}$ \\
\hline \multicolumn{7}{|c|}{ Panel B: Only 8-K filings } \\
\hline \multicolumn{7}{|l|}{ Across firms: } \\
\hline $\begin{array}{l}\text { Abnormal return } \\
\text { t-statistic }\end{array}$ & $\begin{array}{c}0.0172^{* *} \\
(2.60)\end{array}$ & $\begin{array}{c}0.00123 \\
(0.16)\end{array}$ & $\begin{array}{c}0.0118^{*} \\
(1.76)\end{array}$ & $\begin{array}{c}0.0171^{* *} \\
(2.58)\end{array}$ & $\begin{array}{c}0.00378 \\
(0.47)\end{array}$ & $\begin{array}{c}0.0120^{*} \\
(1.69)\end{array}$ \\
\hline \multicolumn{7}{|l|}{ Within firms: } \\
\hline $\begin{array}{l}\text { Abnormal return } \\
\text { t-statistic }\end{array}$ & $\begin{array}{l}0.0172^{* * *} \\
(2.64)\end{array}$ & $\begin{array}{c}0.00127 \\
(0.17)\end{array}$ & $\begin{array}{c}0.0118^{*} \\
(1.75)\end{array}$ & $\begin{array}{c}0.0171^{* * *} \\
(2.62)\end{array}$ & $\begin{array}{c}0.00384 \\
(0.48)\end{array}$ & $\begin{array}{c}0.0121^{*} \\
(1.68)\end{array}$ \\
\hline \multicolumn{7}{|c|}{ Panel C: Only 8-K filings \& non-penny stocks } \\
\hline \multicolumn{7}{|l|}{ Across firms: } \\
\hline $\begin{array}{l}\text { Abnormal return } \\
\text { t-statistic }\end{array}$ & $\begin{array}{c}0.0168^{* *} \\
(2.51)\end{array}$ & $\begin{array}{c}0.00605 \\
(0.79)\end{array}$ & $\begin{array}{c}0.0170^{* *} \\
(2.19)\end{array}$ & $\begin{array}{c}0.0150^{* *} \\
(2.24)\end{array}$ & $\begin{array}{l}0.0107 \\
(1.16)\end{array}$ & $\begin{array}{c}0.0170^{*} \\
(1.94)\end{array}$ \\
\hline \multicolumn{7}{|l|}{ Within firms: } \\
\hline $\begin{array}{l}\text { Abnormal return } \\
\text { t-statistic }\end{array}$ & $\begin{array}{c}0.0168^{* *} \\
(2.59)\end{array}$ & $\begin{array}{c}0.00607 \\
(0.79)\end{array}$ & $\begin{array}{c}0.0171^{* *} \\
(2.13)\end{array}$ & $\begin{array}{c}0.0150^{* *} \\
(2.32)\end{array}$ & $\begin{array}{c}0.0108 \\
(1.15)\end{array}$ & $\begin{array}{c}0.0171^{*} \\
(1.88)\end{array}$ \\
\hline
\end{tabular}




\section{Table IA.B.4 \\ PPP loan repayment propensity \\ Firms with market cap $\geq \$ 50$ million}

This table reports the results from a linear probability (OLS) model where the dependent variable is an indicator for public company returning a PPP loan to the SBA and independent variables are company characteristics, for the subsample of firms that have market capitalization of at least $\$ 50$ million. Continuous variables are winsorized at the $1^{\text {st }}$ and the $99^{\text {th }}$ percentiles. Standard errors are clustered at the industry level, defined as 2-digit NAICS, where we combine industries with few PPP-eligible companies into one bucket. ${ }^{* * *},{ }^{* *}$, and * denote statistical significance at the $1 \%$, $5 \%$, and $10 \%$ levels, respectively. $t$-statistics are presented in parentheses.

\begin{tabular}{|c|c|c|c|}
\hline & \multicolumn{3}{|c|}{ Dependent variable = PPP Loan Returner $(1 / 0)$} \\
\hline & $(1)$ & $(2)$ & $(3)$ \\
\hline Log (Assets) & $\begin{array}{c}0.0763^{* * *} \\
\quad(3.74)\end{array}$ & $\begin{array}{c}0.0696^{* * *} \\
(3.43)\end{array}$ & $\begin{array}{c}0.0854^{* *} \\
(2.86)\end{array}$ \\
\hline Log (Age) & $\begin{array}{c}0.00502 \\
(0.15)\end{array}$ & $\begin{array}{r}0.0167 \\
(0.52)\end{array}$ & $\begin{array}{l}0.0120 \\
(0.44)\end{array}$ \\
\hline Book Equity <0 (1/0) & $\begin{array}{c}-0.0819 \\
(-1.04)\end{array}$ & $\begin{array}{l}-0.107 \\
(-1.36)\end{array}$ & $\begin{array}{c}-0.0871 \\
(-1.18)\end{array}$ \\
\hline Tobin's Q & $\begin{array}{c}0.00476 \\
(1.05)\end{array}$ & $\begin{array}{c}-0.00231 \\
(-0.35)\end{array}$ & $\begin{array}{c}-0.00289 \\
(-0.50)\end{array}$ \\
\hline Current Ratio & $\begin{array}{c}0.0247^{* *} \\
(2.83)\end{array}$ & $\begin{array}{c}0.0230^{*} \\
(2.00)\end{array}$ & $\begin{array}{c}0.0241^{* *} \\
(2.56)\end{array}$ \\
\hline Cash/Non-Cash Assets & $\begin{array}{c}0.00404 \\
(0.41)\end{array}$ & $\begin{array}{c}0.00243 \\
(0.31)\end{array}$ & $\begin{array}{c}0.00389 \\
(0.57)\end{array}$ \\
\hline Penny Stock $(1 / 0)$ & $\begin{array}{c}0.0185 \\
(0.34)\end{array}$ & $\begin{array}{c}-0.00408 \\
(-0.07)\end{array}$ & $\begin{array}{c}-0.0724 \\
(-0.42)\end{array}$ \\
\hline Covid Industry $(1 / 0)$ & & $\begin{array}{l}-0.154 \\
(-1.31)\end{array}$ & $\begin{array}{l}-0.162 \\
(-1.23)\end{array}$ \\
\hline Machinery Industry $(1 / 0)$ & & $\begin{array}{l}-0.104 \\
(-1.70)\end{array}$ & $\begin{array}{l}-0.131 \\
(-1.45)\end{array}$ \\
\hline Health Industry $(1 / 0)$ & & $\begin{array}{l}0.105 \\
(1.33)\end{array}$ & $\begin{array}{c}0.0570 \\
(0.89)\end{array}$ \\
\hline High-Tech Industry $(1 / 0)$ & & $\begin{array}{c}-0.112^{* *} \\
(-2.46)\end{array}$ & $\begin{array}{c}-0.119^{* *} \\
(-2.16)\end{array}$ \\
\hline Covid Period Return & & & $\begin{array}{l}0.469^{*} \\
(1.77)\end{array}$ \\
\hline Covid Period Return $\times$ Penny Stock $(1 / 0)$ & & & $\begin{array}{l}-0.102 \\
(-0.28)\end{array}$ \\
\hline Stimulus Day Return & & & $\begin{array}{c}0.00427 \\
(0.01)\end{array}$ \\
\hline Stimulus Day Return $\times$ Penny Stock $(1 / 0)$ & & & $\begin{array}{l}0.381 \\
(0.63)\end{array}$ \\
\hline PPP Grant Abnormal Return & & & $\begin{array}{l}0.275 \\
(0.67)\end{array}$ \\
\hline PPP Grant Abnormal Return $\times$ Penny Stock $(1 / 0)$ & & & $\begin{array}{l}-0.158 \\
(-0.26) \\
\end{array}$ \\
\hline \# obs. & 212 & 212 & 208 \\
\hline Adjusted $\mathrm{R}^{2}$ & 0.0633 & 0.0765 & 0.0894 \\
\hline
\end{tabular}


Table IA.B.5

\section{PPP loan repayment propensity and distance-to-default}

This table reports the results from a linear probability (OLS) model where the dependent variable is an indicator for public company returning a PPP loan to the SBA and independent variables are Distance-to-Default and other company characteristics. Continuous variables are winsorized at the $1^{\text {st }}$ and the $99^{\text {th }}$ percentiles. Standard errors are clustered at the industry level, defined as 2-digit NAICS, where we combine industries with few PPP-eligible companies into one bucket. ***, **, and ${ }^{*}$ denote statistical significance at the $1 \%, 5 \%$, and $10 \%$ levels, respectively. $t$-statistics are presented in parentheses.

\begin{tabular}{|c|c|c|c|}
\hline & \multicolumn{3}{|c|}{ Dependent variable $=$ PPP Loan Returner $(1 / 0)$} \\
\hline & (1) & $(2)$ & $(3)$ \\
\hline Distance-to-Default & $\begin{array}{c}0.0464^{* * * *} \\
(4.25)\end{array}$ & $\begin{array}{c}0.0541^{* * * *} \\
(4.28)\end{array}$ & $\begin{array}{c}0.0554^{* * * *} \\
(4.51)\end{array}$ \\
\hline Log (Assets) & $\begin{array}{c}0.0990^{* * *} \\
(3.26)\end{array}$ & $\begin{array}{c}0.102^{* *} \\
(2.97)\end{array}$ & $\begin{array}{c}0.107^{* *} \\
(2.92)\end{array}$ \\
\hline Log (Age) & $\begin{array}{c}-0.0350^{*} \\
(-2.09)\end{array}$ & $\begin{array}{c}-0.0236 \\
(-1.64)\end{array}$ & $\begin{array}{c}-0.0273 \\
(-1.77)\end{array}$ \\
\hline Book Equity $<0(1 / 0)$ & $\begin{array}{c}0.00258 \\
(0.04)\end{array}$ & $\begin{array}{c}-0.0149 \\
(-0.34)\end{array}$ & $\begin{array}{c}0.00229 \\
(0.05)\end{array}$ \\
\hline Tobin's Q & $\begin{array}{c}0.0153 \\
(0.93)\end{array}$ & $\begin{array}{c}0.00835 \\
(0.57)\end{array}$ & $\begin{array}{c}0.0103 \\
(1.00)\end{array}$ \\
\hline Current Ratio & $\begin{array}{c}0.00132 \\
(0.33)\end{array}$ & $\begin{array}{c}-0.00147 \\
(-0.45)\end{array}$ & $\begin{array}{c}-0.00191 \\
(-0.63)\end{array}$ \\
\hline Cash/Non-Cash Assets & $\begin{array}{c}-0.00125 \\
(-0.18)\end{array}$ & $\begin{array}{c}-0.00484 \\
(-0.77)\end{array}$ & $\begin{array}{c}-0.00492 \\
(-0.87)\end{array}$ \\
\hline Penny Stock $(1 / 0)$ & $\begin{array}{c}-0.00485 \\
(-0.10)\end{array}$ & $\begin{array}{c}-0.00234 \\
(-0.05)\end{array}$ & $\begin{array}{l}-0.128 \\
(-0.95)\end{array}$ \\
\hline Covid Industry $(1 / 0)$ & & $\begin{array}{c}-0.0746 \\
(-1.61)\end{array}$ & $\begin{array}{c}-0.0830 \\
(-1.74)\end{array}$ \\
\hline Machinery Industry $(1 / 0)$ & & $\begin{array}{c}-0.124^{* *} \\
(-2.88)\end{array}$ & $\begin{array}{c}-0.138^{* *} \\
(-2.60)\end{array}$ \\
\hline Health Industry $(1 / 0)$ & & $\begin{array}{c}0.155^{* *} \\
(2.88)\end{array}$ & $\begin{array}{c}0.138^{* * *} \\
(3.28)\end{array}$ \\
\hline High-Tech Industry $(1 / 0)$ & & $\begin{array}{r}-0.0297 \\
(-0.79)\end{array}$ & $\begin{array}{c}-0.0356 \\
(-0.82)\end{array}$ \\
\hline Covid Period Return & & & $\begin{array}{l}0.239 \\
(1.14)\end{array}$ \\
\hline Covid Period Return $\times$ Penny Stock $(1 / 0)$ & & & $\begin{array}{l}-0.204 \\
(-0.78)\end{array}$ \\
\hline Stimulus Day Return & & & $\begin{array}{c}-0.625^{*} \\
(-1.95)\end{array}$ \\
\hline Stimulus Day Return $\times$ Penny Stock $(1 / 0)$ & & & $\begin{array}{l}0.517 \\
(1.46)\end{array}$ \\
\hline PPP Grant Abnormal Return & & & $\begin{array}{l}0.558 \\
(1.21)\end{array}$ \\
\hline PPP Grant Abnormal Return $\times$ Penny Stock $(1 / 0)$ & & & $\begin{array}{l}-0.565 \\
(-0.98)\end{array}$ \\
\hline \# obs. & 365 & 365 & 364 \\
\hline Adjusted $\mathrm{R}^{2}$ & 0.140 & 0.171 & 0.175 \\
\hline
\end{tabular}




\section{Table IA.B.6 \\ PPP loan repayment announcement effects Firms with market cap $\geq \$ 50$ million}

This table reports the results from a event study analysis where the dependent variable is the company's stock return measured as stock return minus S\&P 500 return (Panel A) or abnormal stock return calculated using the market model based on S\&P 500 return (Panel B), for the subsample of firms that have market capitalization of at least $\$ 50$ million. The key independent variable Day is an indicator for the treading day relative to the PPP loan return announcement date, Day 0 (e.g., 8-K filing, press release). The time period is from Day -60 to Day 1. The estimation window for the market model is Day -270 to Day -61. The day count excludes non-trading days (e.g., weekends, holidays). Continuous variables are winsorized at the $1^{\text {st }}$ and the $99^{\text {th }}$ percentiles. Standard errors are clustered at the trading day level. ***, **, and * denote statistical significance at the $1 \%, 5 \%$, and $10 \%$ levels, respectively. $t$-statistics are presented in parentheses.

\begin{tabular}{|c|c|c|c|c|c|c|}
\hline & \multicolumn{3}{|c|}{ Panel A: Market-adjusted } & \multicolumn{3}{|c|}{ Panel B: Market model } \\
\hline & Day -1 & Day 0 & Day +1 & Day -1 & Day 0 & Day +1 \\
\hline & $(1)$ & $(2)$ & $(3)$ & $(4)$ & $(5)$ & $(6)$ \\
\hline \multicolumn{7}{|c|}{ Panel A: All observations } \\
\hline \multicolumn{7}{|l|}{ Across firms: } \\
\hline $\begin{array}{l}\text { Abnormal return } \\
\text { t-statistic }\end{array}$ & $\begin{array}{c}-0.00973 \\
(-1.46)\end{array}$ & $\begin{array}{c}0.0181^{* * *} \\
(3.09)\end{array}$ & $\begin{array}{c}0.00628 \\
(0.67)\end{array}$ & $\begin{array}{c}-0.0115 \\
(-1.53)\end{array}$ & $\begin{array}{c}0.0189 * * * \\
(2.96)\end{array}$ & $\begin{array}{c}0.00449 \\
(0.46)\end{array}$ \\
\hline \multicolumn{7}{|l|}{ Within firms: } \\
\hline $\begin{array}{l}\text { Abnormal return } \\
\text { t-statistic }\end{array}$ & $\begin{array}{c}-0.00969 \\
(-1.44)\end{array}$ & $\begin{array}{c}0.0181^{* * *} \\
(3.13)\end{array}$ & $\begin{array}{c}0.00491 \\
(0.53)\end{array}$ & $\begin{array}{c}-0.0115 \\
(-1.53)\end{array}$ & $\begin{array}{l}0.0189^{* * *} \\
(2.99)\end{array}$ & $\begin{array}{c}0.00451 \\
(0.46)\end{array}$ \\
\hline \multicolumn{7}{|c|}{ Panel B: Only 8-K filings } \\
\hline \multicolumn{7}{|l|}{ Across firms: } \\
\hline $\begin{array}{l}\text { Abnormal return } \\
\text { t-statistic }\end{array}$ & $\begin{array}{c}-0.0159 * * \\
(-2.43)\end{array}$ & $\begin{array}{c}0.0210^{* * *} \\
(2.72)\end{array}$ & $\begin{array}{c}0.00771 \\
(0.70)\end{array}$ & $\begin{array}{c}-0.0184^{* *} \\
(-2.50)\end{array}$ & $\begin{array}{c}0.0224 * * * \\
(2.72)\end{array}$ & $\begin{array}{c}0.00600 \\
(0.52)\end{array}$ \\
\hline \multicolumn{7}{|l|}{ Within firms: } \\
\hline $\begin{array}{l}\text { Abnormal return } \\
\text { t-statistic }\end{array}$ & $\begin{array}{c}-0.0159^{* *} \\
(-2.47)\end{array}$ & $\begin{array}{c}0.0210^{* * *} \\
(2.75)\end{array}$ & $\begin{array}{c}0.00771 \\
(0.70)\end{array}$ & $\begin{array}{c}-0.0184^{* *} \\
(-2.54)\end{array}$ & $\begin{array}{l}0.0224^{* * *} \\
\quad(2.75)\end{array}$ & $\begin{array}{c}0.00600 \\
(0.52)\end{array}$ \\
\hline \multicolumn{7}{|c|}{ Panel C: Only 8-K filings \& non-penny stocks } \\
\hline \multicolumn{7}{|l|}{ Across firms: } \\
\hline $\begin{array}{l}\text { Abnormal return } \\
\text { t-statistic }\end{array}$ & $\begin{array}{c}-0.0178^{* *} \\
(-2.10)\end{array}$ & $\begin{array}{c}0.0292^{* * *} \\
(2.73)\end{array}$ & $\begin{array}{c}0.00654 \\
(0.48)\end{array}$ & $\begin{array}{c}-0.0204^{* *} \\
(-2.10)\end{array}$ & $\begin{array}{l}0.0310^{* * *} \\
(2.71)\end{array}$ & $\begin{array}{c}0.00583 \\
(0.41)\end{array}$ \\
\hline \multicolumn{7}{|l|}{ Within firms: } \\
\hline $\begin{array}{l}\text { Abnormal return } \\
\text { t-statistic }\end{array}$ & $\begin{array}{c}-0.0178^{* *} \\
(-2.06)\end{array}$ & $\begin{array}{c}0.0292^{* * *} \\
(2.75)\end{array}$ & $\begin{array}{c}0.00654 \\
(0.48)\end{array}$ & $\begin{array}{c}-0.0204^{* *} \\
(-2.10)\end{array}$ & $\begin{array}{c}0.0310^{* * *} \\
(2.71)\end{array}$ & $\begin{array}{c}0.00583 \\
(0.41)\end{array}$ \\
\hline
\end{tabular}


Table IA.B.7

\section{Propensity to borrow early and big-10 banks: SBA PPP data PPP loan size - Lenders with $>450$ PPP loans}

This table reports the results from a linear probability (OLS) model based on SBA PPP data where the dependent variable is a dummy for an early PPP borrower. We exclude lenders with $\leq 450 \mathrm{PPP}$ loans. The key independent variables are interactions between PPP loan size bin dummies (as binned by SBA) and a dummy for a big-10 bank, Big-10 Bank. We classify the following banks as big-10 banks: JPMorgan Chase Bank, Wells Fargo Bank, Bank of America, Citibank, U.S. Bank, Truist Bank, PNC Bank, Bank of New York, State Street Corporation, and TD Bank. Continuous variables are winsorized at the $1^{\text {st }}$ and the $99^{t h}$ percentiles. Standard errors are clustered at the industry level, defined as 2-digit NAICS. ***, **, and * denote statistical significance at the $1 \%$, $5 \%$, and $10 \%$ levels, respectively. $t$-statistics are presented in parentheses.

\begin{tabular}{|c|c|c|c|c|}
\hline & \multicolumn{4}{|c|}{ Dependent variable $=$ Early PPP Borrower $(1 / 0)$} \\
\hline & \multicolumn{2}{|c|}{ All Firms } & \multicolumn{2}{|c|}{ Only Corporations } \\
\hline & (1) & $(2)$ & $(3)$ & (4) \\
\hline $\operatorname{Big}-10 \operatorname{Bank}(1 / 0) \times$ Loan $[\$ 5-10 \mathrm{M}](1 / 0)$ & $\begin{array}{c}0.140^{* * *} \\
(9.78)\end{array}$ & $\begin{array}{c}0.184^{* * *} \\
(15.38)\end{array}$ & $\begin{array}{c}0.153^{* * *} \\
(5.84)\end{array}$ & $\begin{array}{l}0.179^{* * *} \\
(8.76)\end{array}$ \\
\hline Big-10 Bank $(1 / 0) \times$ Loan $[\$ 2-5 \mathrm{M}](1 / 0)$ & $\begin{array}{l}0.0936^{* * * *} \\
\quad(6.24)\end{array}$ & $\begin{array}{c}0.131^{* * *} \\
(8.20)\end{array}$ & $\begin{array}{l}0.0708^{* * *} \\
(5.44)\end{array}$ & $\begin{array}{c}0.115^{* * *} \\
(9.79)\end{array}$ \\
\hline Big-10 Bank $(1 / 0) \times$ Loan $[\$ 1-2 \mathrm{M}](1 / 0)$ & $\begin{array}{c}0.0552^{* *} \\
(2.66)\end{array}$ & $\begin{array}{l}0.0924^{* * *} \\
(4.10)\end{array}$ & $\begin{array}{c}0.0295 \\
(1.42)\end{array}$ & $\begin{array}{l}0.0703^{* * *} \\
(3.23)\end{array}$ \\
\hline Big-10 Bank $(1 / 0) \quad \times$ Loan $[\$ 350 k-1 M](1 / 0)$ & $\begin{array}{c}-0.0403^{* *} \\
(-2.38)\end{array}$ & $\begin{array}{c}-0.00430 \\
(-0.25)\end{array}$ & $\begin{array}{c}-0.0603^{* * *} \\
(-5.30)\end{array}$ & $\begin{array}{c}-0.0176 \\
(-1.46)\end{array}$ \\
\hline $\operatorname{Big}-10 \operatorname{Bank}(1 / 0) \times$ Loan $[\$ 150-350 \mathrm{k}](1 / 0)$ & $\begin{array}{c}-0.115^{* * *} \\
(-10.85)\end{array}$ & $\begin{array}{l}-0.0842^{* * *} \\
(-9.68)\end{array}$ & $\begin{array}{c}-0.106^{* * *} \\
(-14.34)\end{array}$ & $\begin{array}{c}-0.0696^{* * *} \\
(-12.37)\end{array}$ \\
\hline Loan $[\$ 5-10 \mathrm{M}](1 / 0)$ & $\begin{array}{c}0.379^{* * *} \\
(11.39)\end{array}$ & $\begin{array}{c}0.316^{* * *} \\
(11.19)\end{array}$ & $\begin{array}{c}0.338^{* * *} \\
(9.78)\end{array}$ & $\begin{array}{c}0.287^{* * *} \\
(10.71)\end{array}$ \\
\hline Loan $[\$ 2-5 \mathrm{M}](1 / 0)$ & $\begin{array}{c}0.428^{* * *} \\
(21.25)\end{array}$ & $\begin{array}{c}0.358 * * * \\
(20.55)\end{array}$ & $\begin{array}{c}0.403^{* * *} * \\
(25.61)\end{array}$ & $\begin{array}{c}0.332^{* * *} \\
(25.27)\end{array}$ \\
\hline Loan $[\$ 1-2 \mathrm{M}](1 / 0)$ & $\begin{array}{c}0.395^{* * *} \\
(19.31)\end{array}$ & $\begin{array}{c}0.326^{* * *} \\
(18.57)\end{array}$ & $\begin{array}{c}0.372^{* * *} * \\
(24.71)\end{array}$ & $\begin{array}{c}0.301^{* * *} \\
(24.95)\end{array}$ \\
\hline Loan $[\$ 350 \mathrm{k}-1 \mathrm{M}](1 / 0)$ & $\begin{array}{c}0.352^{* * *} \\
(25.51)\end{array}$ & $\begin{array}{c}0.288^{* * *} \\
(24.34)\end{array}$ & $\begin{array}{c}0.325^{* * *} \\
(30.32)\end{array}$ & $\begin{array}{c}0.258^{* * *} \\
(30.62)\end{array}$ \\
\hline Loan $[\$ 150-350 \mathrm{k}](1 / 0)$ & $\begin{array}{c}0.268^{* * *} \\
(29.13)\end{array}$ & $\begin{array}{c}0.217^{* * *} \\
(25.82)\end{array}$ & $\begin{array}{c}0.235^{* * *} \\
(31.15)\end{array}$ & $\begin{array}{c}0.181^{* * *} \\
(28.62)\end{array}$ \\
\hline Big-10 Bank (1/0) & $\begin{array}{c}-0.196^{* * *} \\
(-28.48)\end{array}$ & & $\begin{array}{c}-0.251^{* * *} \\
(-42.05)\end{array}$ & \\
\hline NAICS-2 \& ZIP-5 FE & Yes & Yes & Yes & Yes \\
\hline Business Type FE & Yes & Yes & - & - \\
\hline Lender FE & - & Yes & - & Yes \\
\hline \# obs. & $4,550,076$ & $4,550,076$ & $1,327,922$ & $1,327,922$ \\
\hline Adjusted $\mathrm{R}^{2}$ & 0.236 & 0.367 & 0.256 & 0.395 \\
\hline
\end{tabular}


Table IA.B.8

\section{Propensity to borrow early and big-10 banks: SBA PPP data Jobs supported by PPP - Lenders with >450 PPP loans}

This table reports the results from a linear probability (OLS) model based on SBA PPP data where the dependent variable is a dummy for an early PPP borrower. We exclude lenders with $\leq 450 \mathrm{PPP}$ loans. The key independent variables are interactions between the number of jobs supported by PPP (binned as per BLS classification) and a dummy for a big-10 bank, Big-10 Bank. We group the jobs variable into buckets using firm size classification by the Bureau of Labor Statistics (BLS) because the distribution of this variable is highly skewed even after log-transformation. Continuous variables are winsorized at the $1^{\text {st }}$ and the $99^{\text {th }}$ percentiles. Standard errors are clustered at the industry level, defined as 2-digit NAICS. ***, **, and * denote statistical significance at the $1 \%$, $5 \%$, and $10 \%$ levels, respectively. $t$-statistics are presented in parentheses.

\begin{tabular}{|c|c|c|c|c|c|}
\hline & & \multicolumn{4}{|c|}{ Dependent variable $=$ Early PPP Borrower $(1 / 0)$} \\
\hline & & \multicolumn{2}{|c|}{ All Firms } & \multicolumn{2}{|c|}{ Only Corporations } \\
\hline & & (1) & $(2)$ & $(3)$ & (4) \\
\hline Big-10 Bank (1/0) $\times$ & $\times$ Jobs $[250+](1 / 0)$ & $\begin{array}{c}0.0284^{*} \\
(1.80)\end{array}$ & $\begin{array}{c}0.00773 \\
(0.40)\end{array}$ & $\begin{array}{c}-0.00491 \\
(-0.22)\end{array}$ & $\begin{array}{c}-0.00928 \\
(-0.42)\end{array}$ \\
\hline Big-10 Bank $(1 / 0) \times$ & $\times$ Jobs $[100-249](1 / 0)$ & $\begin{array}{c}0.000744 \\
(0.04)\end{array}$ & $\begin{array}{c}-0.0148 \\
(-0.64)\end{array}$ & $\begin{array}{c}-0.0366^{*} \\
(-1.80)\end{array}$ & $\begin{array}{c}-0.0424^{*} \\
(-1.85)\end{array}$ \\
\hline Big-10 Bank (1/0) $\times$ & $\times$ Jobs [50-99] $(1 / 0)$ & $\begin{array}{c}-0.0583^{* *} \\
(-2.55)\end{array}$ & $\begin{array}{c}-0.0731^{* * *} \\
(-3.12)\end{array}$ & $\begin{array}{c}-0.0785^{* * *} \\
(-4.03)\end{array}$ & $\begin{array}{c}-0.0815^{* * *} \\
(-4.17)\end{array}$ \\
\hline $\operatorname{Big}-10 \operatorname{Bank}(1 / 0) \quad \times$ & $\times$ Jobs $[20-49](1 / 0)$ & $\begin{array}{c}-0.134^{* * *} \\
(-10.04)\end{array}$ & $\begin{array}{c}-0.136^{* * *} \\
(-11.53)\end{array}$ & $\begin{array}{c}-0.138^{* * *} \\
(-11.22)\end{array}$ & $\begin{array}{c}-0.127^{* * *} \\
(-11.93)\end{array}$ \\
\hline $\operatorname{Big}-10 \operatorname{Bank}(1 / 0) \times$ & $\times$ Jobs $[10-19](1 / 0)$ & $\begin{array}{c}-0.145^{* * *} \\
(-16.69)\end{array}$ & $\begin{array}{c}-0.133^{* * *} \\
(-17.42)\end{array}$ & $\begin{array}{c}-0.133^{* * *} \\
(-15.46)\end{array}$ & $\begin{array}{c}-0.112^{* * *} \\
(-16.16)\end{array}$ \\
\hline Big-10 Bank $(1 / 0) \times$ & $\times$ Jobs $[5-9](1 / 0)$ & $\begin{array}{c}-0.121^{* * *} \\
(-17.94)\end{array}$ & $\begin{array}{c}-0.106^{* * *} \\
(-16.56)\end{array}$ & $\begin{array}{c}-0.0989 * * * \\
(-14.72)\end{array}$ & $\begin{array}{c}-0.0790^{* * *} \\
(-13.98)\end{array}$ \\
\hline Jobs $[250+](1 / 0)$ & & $\begin{array}{c}0.443^{* * *} \\
(15.19)\end{array}$ & $\begin{array}{c}0.368^{* * *} \\
(15.39)\end{array}$ & $\begin{array}{c}0.416^{* * * *} \\
(17.94)\end{array}$ & $\begin{array}{c}0.335^{* * *} \\
(17.40)\end{array}$ \\
\hline Jobs $[100-249](1 / 0)$ & & $\begin{array}{c}0.460^{* * *} \\
(17.56)\end{array}$ & $\begin{array}{c}0.380^{* * *} \\
(16.78)\end{array}$ & $\begin{array}{c}0.441^{* * *} \\
(22.32)\end{array}$ & $\begin{array}{c}0.353^{* * *} \\
(21.12)\end{array}$ \\
\hline Jobs [50-99] (1/0) & & $\begin{array}{c}0.427^{* * *} \\
(22.97)\end{array}$ & $\begin{array}{c}0.352^{* * *} \\
(22.57)\end{array}$ & $\begin{array}{c}0.402^{* * *} \\
(26.50)\end{array}$ & $\begin{array}{c}0.319^{* * *} \\
(26.11)\end{array}$ \\
\hline Jobs [20-49] (1/0) & & $\begin{array}{c}0.356^{* * *} \\
(34.92)\end{array}$ & $\begin{array}{c}0.291 * * * \\
(30.01)\end{array}$ & $\begin{array}{c}0.330^{* * *} \\
(34.53)\end{array}$ & $\begin{array}{c}0.254^{* * *} \\
(27.97)\end{array}$ \\
\hline Jobs $[10-19](1 / 0)$ & & $\begin{array}{c}0.259^{* * *} \\
(35.91)\end{array}$ & $\begin{array}{c}0.211^{* * *} \\
(28.33)\end{array}$ & $\begin{array}{c}0.233^{* * *} \\
(35.36)\end{array}$ & $\begin{array}{c}0.177^{* * *} \\
(26.85)\end{array}$ \\
\hline Jobs $[5-9](1 / 0)$ & & $\begin{array}{c}0.177^{* * *} * \\
(25.83)\end{array}$ & $\begin{array}{c}0.145^{* * *} \\
(21.77)\end{array}$ & $\begin{array}{c}0.152^{* * *} \\
(29.59)\end{array}$ & $\begin{array}{c}0.113^{* * *} \\
(24.14)\end{array}$ \\
\hline Big-10 Bank (1/0) & & $\begin{array}{c}-0.140^{* * *} \\
(-16.67) \\
\end{array}$ & & $\begin{array}{c}-0.176^{* * * *} \\
(-17.93) \\
\end{array}$ & \\
\hline NAICS-2 \& ZIP-5 FE & & Yes & Yes & Yes & Yes \\
\hline Business Type FE & & Yes & Yes & - & - \\
\hline Lender FE & & - & Yes & - & Yes \\
\hline \# obs. & & $3,683,719$ & $3,683,714$ & $1,074,895$ & $1,074,892$ \\
\hline Adjusted $\mathrm{R}^{2}$ & & 0.250 & 0.385 & 0.252 & 0.399 \\
\hline
\end{tabular}




\section{Table IA.B.9 \\ Early PPP borrowers and lender effects: SBA PPP data PPP loan size - Lenders with $>450$ PPP loans}

This table reports the results from a multinomial logit model based on SBA PPP data where the dependent variable is a categorical variable for the intersection between a bank type (big-10 bank versus smaller bank) and borrower type (early versus late PPP borrower). We exclude lenders with $\leq 450$ PPP loans. The independent variables are the PPP loan size bin dummies (as binned by SBA). The dependent variable Bank Type-Borrower Type Category (Y) takes the value of 3 for big10 bank and early PPP borrower, 2 for big-10 bank and late PPP borrower, 1 for smaller bank and early PPP borrower, and 0 for smaller bank and late PPP borrower. We classify the following banks as big-10 banks: JPMorgan Chase Bank, Wells Fargo Bank, Bank of America, Citibank, U.S. Bank, Truist Bank, PNC Bank, Bank of New York, State Street Corporation, and TD Bank. An early borrower is a public company receiving a PPP loan before April 17, 2020. Continuous variables are winsorized at the $1^{\text {st }}$ and the $99^{\text {th }}$ percentiles. Standard errors are clustered at the industry level, defined as 2-digit NAICS, where we combine industries with few PPP-eligible companies into one bucket. $* * *, * *$, and $*$ denote statistical significance at the $1 \%, 5 \%$, and $10 \%$ levels, respectively. $z$-statistics are presented in parentheses.

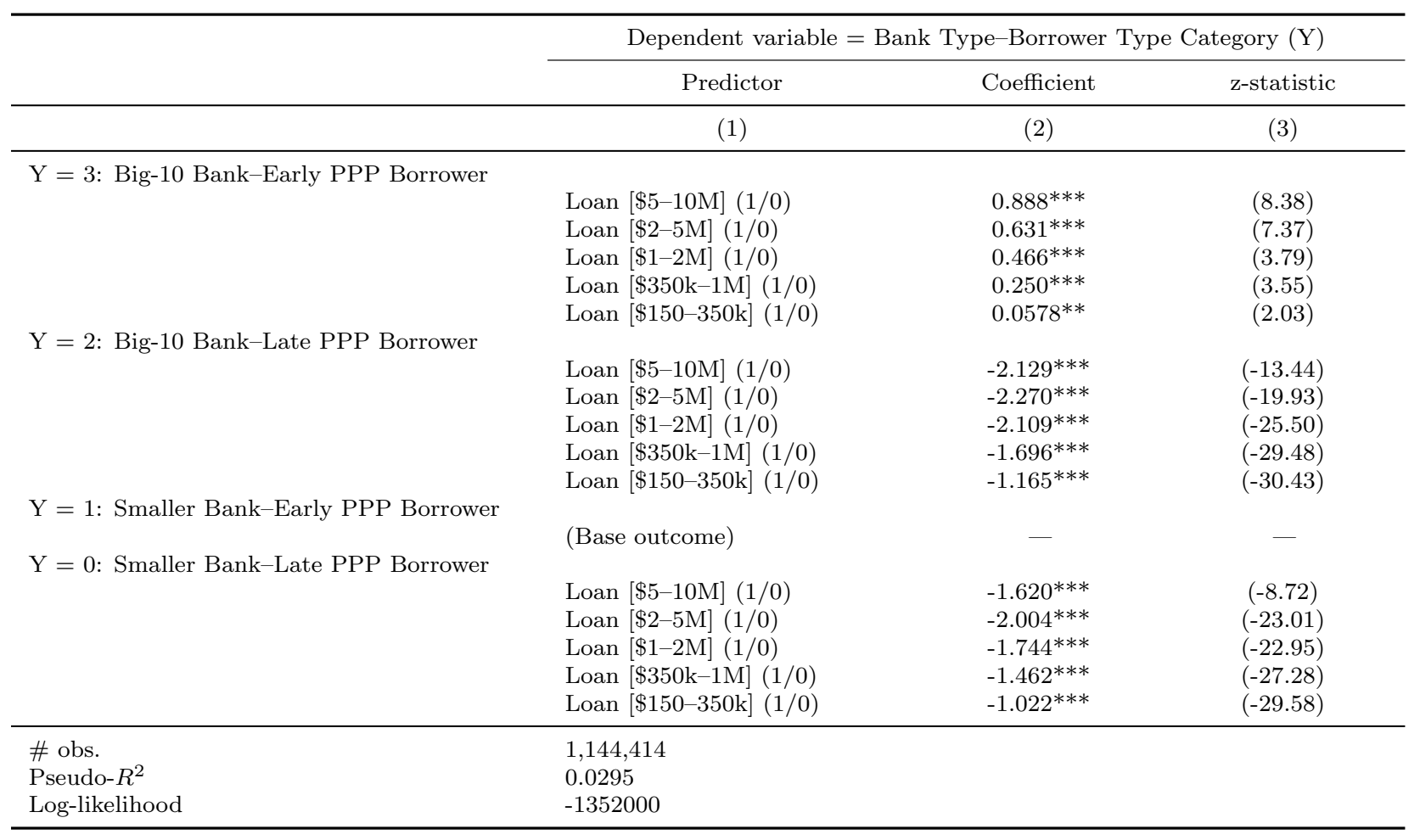




\section{Table IA.B.10 \\ Early PPP borrowers and lender effects: SBA PPP data Jobs supported by PPP - Lenders with >450 PPP loans}

This table reports the results from a multinomial logit model based on SBA PPP data where the dependent variable is a categorical variable for the intersection between a bank type (big-10 bank versus smaller bank) and borrower type (early versus late PPP borrower). We exclude lenders with $\leq 450$ PPP loans. The independent variable is the number of jobs supported by PPP (binned as per BLS classification). We group the jobs variable into buckets using firm size classification by the Bureau of Labor Statistics (BLS) because the distribution of this variable is highly skewed even after log-transformation. The dependent variable Bank Type-Borrower Type Category $(Y)$ takes the value of 3 for big-10 bank and early PPP borrower, 2 for big-10 bank and late PPP borrower, 1 for smaller bank and early PPP borrower, and 0 for smaller bank and late PPP borrower. We classify the following banks as big-10 banks: JPMorgan Chase Bank, Wells Fargo Bank, Bank of America, Citibank, U.S. Bank, Truist Bank, PNC Bank, Bank of New York, State Street Corporation, and TD Bank. An early borrower is a public company receiving a PPP loan before April 17, 2020. Continuous variables are winsorized at the $1^{\text {st }}$ and the $99^{\text {th }}$ percentiles. Standard errors are clustered at the industry level, defined as 2-digit NAICS, where we combine industries with few PPP-eligible companies into one bucket. $* * *, * *$, and $*$ denote statistical significance at the $1 \%$, $5 \%$, and $10 \%$ levels, respectively. $z$-statistics are presented in parentheses.

\begin{tabular}{|c|c|c|c|}
\hline & \multicolumn{3}{|c|}{ Dependent variable $=$ Bank Type-Borrower Type Category $(\mathrm{Y})$} \\
\hline & Predictor & Coefficient & z-statistic \\
\hline & $(1)$ & $(2)$ & $(3)$ \\
\hline \multicolumn{4}{|c|}{$\mathrm{Y}=3:$ Big-10 Bank-Early PPP Borrower } \\
\hline & Jobs $[250+](1 / 0)$ & $0.542^{* * *}$ & $(7.47)$ \\
\hline & Jobs [100-249] $(1 / 0)$ & $0.349 * * *$ & $(3.71)$ \\
\hline & Jobs $[50-99](1 / 0)$ & $0.186^{* *}$ & $(2.00)$ \\
\hline & Jobs $[20-49](1 / 0)$ & 0.0340 & $(0.59)$ \\
\hline & Jobs $[10-19](1 / 0)$ & -0.0560 & $(-1.20)$ \\
\hline & Jobs $[5-9](1 / 0)$ & -0.0604 & $(-1.36)$ \\
\hline \multicolumn{4}{|c|}{$\mathrm{Y}=2$ : Big-10 Bank-Late PPP Borrower } \\
\hline & Jobs $[250+](1 / 0)$ & $-2.047^{* * *}$ & $(-17.18)$ \\
\hline & Jobs [100-249] $(1 / 0)$ & $-2.246^{* * *}$ & $(-20.43)$ \\
\hline & Jobs [50-99] $(1 / 0)$ & $-2.048^{* * *}$ & $(-23.58)$ \\
\hline & Jobs $[20-49](1 / 0)$ & $-1.521^{* * *}$ & $(-25.13)$ \\
\hline & Jobs [10-19] $(1 / 0)$ & $-1.045^{* * *}$ & $(-24.93)$ \\
\hline \multirow{2}{*}{\multicolumn{4}{|c|}{$\mathrm{Y}=1:$ Smaller Bank-Early PPP Borrower }} \\
\hline & & & \\
\hline & (Base outcome) & - & - \\
\hline \multicolumn{4}{|c|}{$\mathrm{Y}=0$ : Smaller Bank-Late PPP Borrower } \\
\hline & Jobs $[250+](1 / 0)$ & $-1.862^{* * *}$ & $(-15.46)$ \\
\hline & Jobs [100-249] $(1 / 0)$ & $-2.049^{* * *}$ & $(-19.18)$ \\
\hline & Jobs $[50-99](1 / 0)$ & $-1.778^{* * *}$ & $(-20.92)$ \\
\hline & Jobs $[20-49](1 / 0)$ & $-1.399^{* * *}$ & $(-23.25)$ \\
\hline & Jobs $[10-19](1 / 0)$ & $-0.974^{* * *}$ & $(-22.48)$ \\
\hline & Jobs $[5-9](1 / 0)$ & $-0.649 * * *$ & $(-21.19)$ \\
\hline \# obs. & 908,428 & & \\
\hline Pseudo- $R^{2}$ & 0.0342 & & \\
\hline Log-likelihood & -1078000 & & \\
\hline
\end{tabular}

